Portland State University

PDXScholar

1978

\title{
The stratigraphy and structure of the Columbia River basalt in the Clackamas River drainage
}

James Lee Anderson

Portland State University

Follow this and additional works at: https://pdxscholar.library.pdx.edu/open_access_etds

Part of the Geology Commons, and the Stratigraphy Commons

Let us know how access to this document benefits you.

\section{Recommended Citation}

Anderson, James Lee, "The stratigraphy and structure of the Columbia River basalt in the Clackamas River drainage" (1978). Dissertations and Theses. Paper 3511.

https://doi.org/10.15760/etd.5395

This Thesis is brought to you for free and open access. It has been accepted for inclusion in Dissertations and Theses by an authorized administrator of PDXScholar. Please contact us if we can make this document more accessible: pdxscholar@pdx.edu. 
AN ABSTRACT OF THE THESIS OF James Lee Anderson for the Master of Science in Geology presented July 17, 1978.

Title: The Stratigraphy and structure of the Columbia River Basalt in the Clackamas River Drainage.

APPROVED BY MEMBERS OF THE THESIS COMMITTEE:

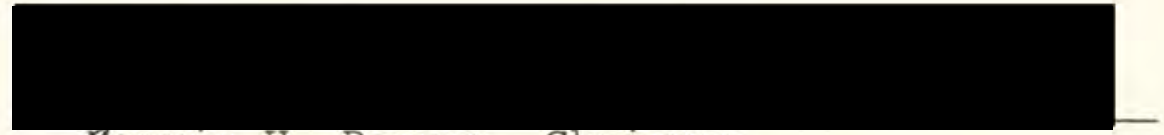

Rlarvin H. Beeson, Chairman

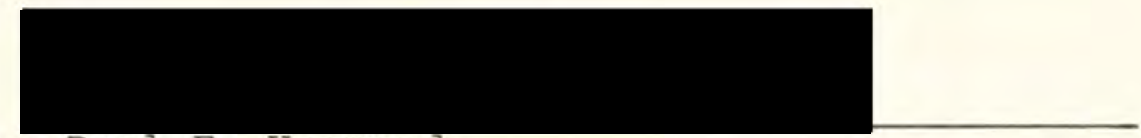

Paul E. Hammond

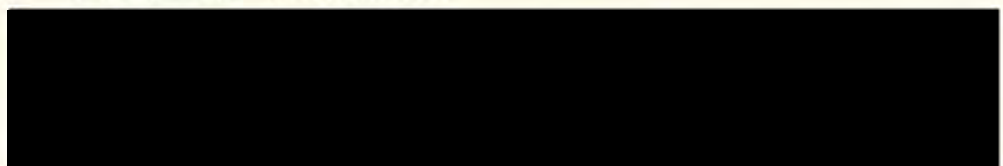

Ansel G. Johnson

The Clackamas River drainage within the western

Cascade Range is approximately aligned with a northwest trending lineation defined by the Portland Hills and the Brothers Fault zone. This area is occupied by an extensive Columbia River Basalt sequence that is deeply incised by the Clackamas River and its tributaries. Two major basalt units of the Yakima Basalt Subgroup, including the Grande Ronde Basalt and the Frenchman Springs Member of the Wanapum Basalt, are distinguishable in a 515 meter to 550 meter accumulation. of particular interest is the presence of five 
trending right-lateral strike-slip faults is consistent with a stress model of north-south compression and east-west extension. 


\title{
THE STRATIGRAPHY AND STRUCTURE OF THE COLUMBIA RIVER BASALT IN THE \\ CLACKAMAS RIVER DRAINAGE
}

\author{
by \\ JAMES LEE ANDERSON
}

A thesis submitted in partial fulfillment of the requirements for the degree of

\author{
MASTER OF SCIENCE \\ in \\ GEOLOGY
}

\author{
Portland State University \\ 1978
}


TO THE OFFICE OF GRADUATE STUDIES AND RESEARCH:

The members of the Committee approve the thesis of James Lee Anderson presented July 17, 1978.

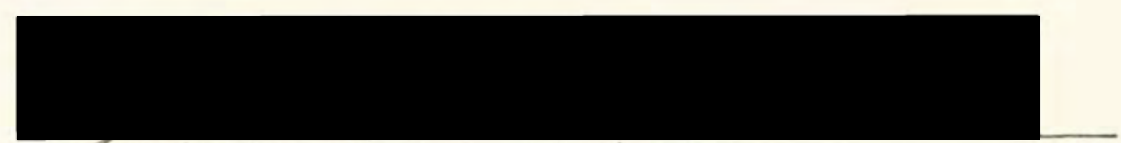

Marvin H. Beeson, Chairman

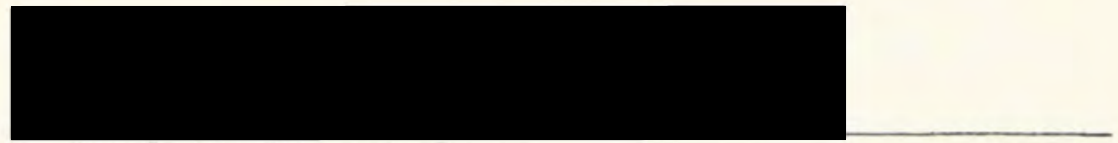

Paul E. Hammond

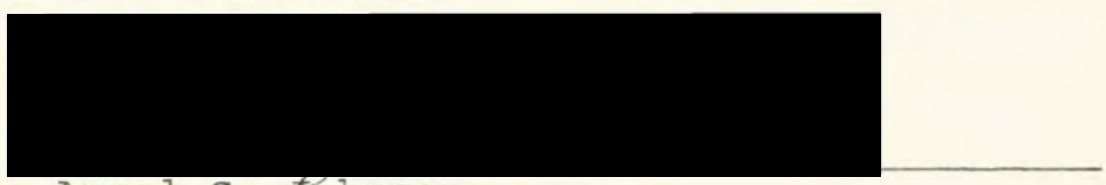

Ansel G. Johnson

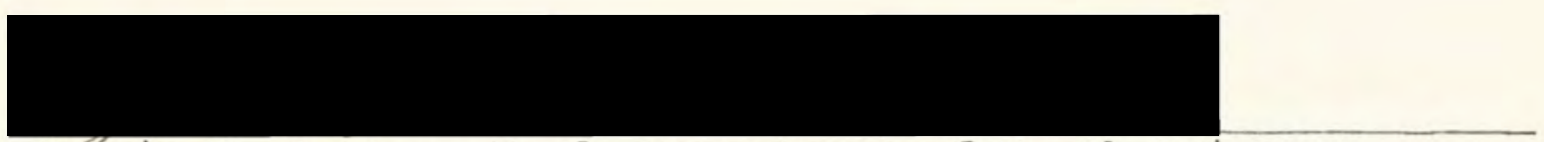

Mafvin H. Beeson, Head, Department of Earth Sciences

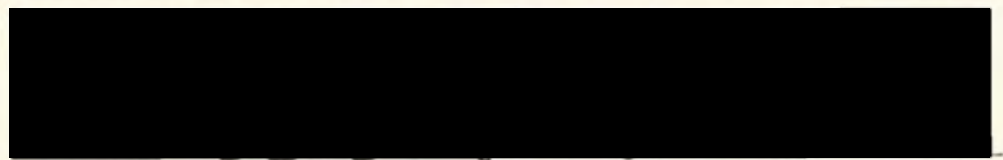

Stanley E. Rauch, Dean of Graduate studies and Research 


\section{ACKNOWLEDGMENTS}

My deepest gratitude is extended to Dr. Marvin H. Beeson, whose advice was critical to the completion of this thesis, and whose enthusiasm and interest was exceeded only by my own. Sincere thanks is also richly deserved by Michael R. Moran who unselfishly contributed his time and technical assistance in both the laboratory and data processing phases of the Instrumental Neutron Activation Analysis procedures. Additional thanks is extended to Terry Tolan who provided valuable laboratory assistance during this process.

Reed College generously provided the use of their Triga Mark 1 nuclear reactor and high resolution detector and multi-channel analyzer without which critical analyses would not have been possible.

Major oxide geochemical analyses were provided by Dr. Peter R. Hooper at Washington State University through the arrangements of Dr. Robert D. Bentley, Jr. from Central Washington State University. Dr. Bentley also provided valuable advice and encouragement on numerous occasions during the latter phases of this project.

Shannon \& Wilson, Inc. provided material support that was helpful in the drafting and reproduction of the final work. In particular, Dr. Rick Kienle provided additional 
data on paleomagnetics and discussed various aspects of this thesis.

My wife, Fely, has never ceased to be a source of assistance, encouragement and inspiration, the true value of which cannot be quantitized. 
TABLE OF CONTENTS

PAGE

ACKNOWLEDGMENTS

iii

LIST OF TABLES

LIST OF FIGURES

CHAPTER

I INTRODUCTION ................ 1

Geographic Setting . . . . . . . 3

Procedure and Methods of

Investigation . . . . . . . . . . . 6

II REGIONAL GEOLOGY ............ 10

Grande Ronde Basalt . . . . . . . 13

Vantage Member ........... 14

Wanapum Basalt . . . . . . . . 14

III STRATIGRAPHY . . . . . . . . . . . 16

Grande Ronde Basalt . . . . . . . . 16

High Mgo/Low Mgo Grande Ronde Basalt Types ......... 18

Prineville Geochemical Type . . . . 22

Magnetostratigraphy . . . . . . . 26

Petrography ............ . 31

Physical Characteristics . . . . 34

Vantage Member and Other

Interbedded Units . . . . . . . . 39

Frenchman Springs Member of

Wanapum Basalt . . . ..... 46 
Correlation within the Clackamas

River Area . . . . . . . . .

Grande Ronde Basalt . . . . . . 54

Frenchman Springs Member . . . . 57

IV STRUCTURE 62

Folds............. . . 63

Northwest Trending Faults

Third Creek Fault . . . . . . 67

Big Cliff Fault . . . . . . . 70

First Creek Fault . . . . . . . 71

Lockaby Fault . . . . . . . . 71

Canyon Creek Fault . . . . . . . 74

Lake Harriet Fault . . . . . . . 75

Huxley Lake Fault . . . . . . . 78

South Fork Fault.. . . . . . . 79

Indian Ridge Fault . . . . . . 80

Northeast Trending Fault

Promontory Park Fault . . . . . 80

North-south Trending Faults

Dinner Creek Fault . . . . . . 83

Other Faulting . . . . . . . 85

Tectonic Summary . . . . . . . 85

V GEOLOGIC HISTORY . . . . . . . . . . . 87

VI SUMMARY AND CONCLUSIONS • . . . . . . . . 95

REFERENCES CITED • • • • • • . • • • • • • • • • . • 99

APPENDIXES

A GEOCHEMICAL CONTROL SECTIONS . . . . . . 102

Big Cliff

Fish Creek Forest Camp

Fish Creek Airstrip

Roaring River

Three Lynx 
B OTHER STRATIGRAPHIC SECTIONS •. . . . . 118

Third Creek

Wanderers Peak

Promontory Park

S $562 \mathrm{~A}$

Big Eddy

Cripple Creek

Ripple Brook

Canyon Creek

Big Creek

Whale Head

Memaloose Road

C TRACE ELEMENT GEOCHEMISTRY - . . . . .

D MAJOR OXIDE GEOCHEMISTRY • • • . • • . • 135 


\section{LIST OF TABLES}

TABLE

PAGE

I Comparison of Clackamas River and Columbia Plateau Major Oxide Concentrations for the High Mgo/Low Mgo Geochemical Types . . 20

I Comparison of Clackamas River Trace Element Concentrations to those of other areas for the High Mgo/Low Mgo Geochemical Types . . . . . . . . . . . .

II Comparison of Clackamas River Trace Element Concentrations with other areas for the Prineville Geochemical Type . . . . . .

IV Comparison of Clackamas River Major Oxide

Concentrations with other areas for the Prineville Geochemical Type . . . . . .

V Distinctive Petrographic Characteristics for

Clackamas River Columbia River Basalt .

VI Comparison of Clackamas River $\mathrm{Fe}, \mathrm{Na}$ and

Trace Element Concentrations with those

of the Type Localities for the Frenchman Springs Member . . . . . . . . . .

VII Trace Element Geochemical Analyses (including $\mathrm{Fe}$ and $\mathrm{Na}$ )............. 134 VIII Major Oxide Geochemical Analyses . . . . . 136 


\section{LIST OF FIGURES}

FIGURE

PAGE

1. Location Map for the Clackamas River study Area . . . . . . . . . . . . . 4

2. Important Geographic Localities . . . . . . 5

3. Regional Distribution of Columbia River Basalt. . . . . . . . . . . . . 11

4. Generalized Stratigraphic column for the

Yakima Basalt Subgroup . . . . . . . . 12

5. Generalized Stratigraphic Column for the

Columbia River Basalt in the Clackamas

River Area . . . . . . . . . . . 17

6. Paleomagnetics Sample Localities at Big Cliff. - 29

7. Vantage Interbed Overlying High MgO Grande

Ronde Basalt . . . . . . . . . 36

8. Columnar Jointing in Prineville Flows at

Big Eddy . . . . . . . . . . . . . 38

9. Interbed within the Low Mgo Grande Ronde

Basalt . . . . . . . . . . . . 40

10. Frenchman Springs Member Flows, Three Lynx

Stratigraphic Section . . . . . . 51

11. Correlation of Geochemical sections for the

Grande Ronde Basalt . . . . . . . 55

12. Geologic Map . . . . . . . (map pocket) 
13. Columnar Sections Detailing the Southern Margin of the Columbia River Basalt . . . . . . 58

14. Correlation of Columnar Sections for the

Frenchman Springs Member in the Clackamas

River Area . . . . . . . . . 60

15. Tectonic Map . . . . . . . . . . . 64

16. Horizontal Slickensides at the Third Creek

Fault.............. 68

17. Cross Sections . . . . . . . (map pocket)

18. Lockaby Fault Exposure . . . . . . . . . 73

19. Lake Harriet Fault Exposure . . . . . . . . 76

20. Road Cut near Promontory Park . • . . . • . 82

21. Dinner Creek Fault Exposure . . . . . . . . 84

22. Location Map for Big Cliff Section . . . . . 103

23. Big Cliff Sample Localities . . . . . . . 104

24. Big Cliff Stratigraphic Section . . . . . . 105

25. Location Map for Fish Creek Forest Camp

Section .............. 106

26. Fish Creek Forest Camp Sample Localities . . . 107

27. Fish Creek Forest Camp Stratigraphic Section . . 108

28. Location Map for Fish Creek Airstrip Section . 109

29. Fish Creek Airstrip Sample Localities . . . 110

30. Fish Creek Airstrip Stratigraphic Section . • 111

31. Location Map for Roaring River Section . . . 112

32. Flows Sampled in Roaring River Area . . . . 113 
33. Roaring River Stratigraphic Section . . . . . 114

34. Location Map for Three Lynx Section ...... 115

35. Three Lynx Sample Localities. . . . . . . 116

36. Three Lynx Stratigraphic Section. . . . . . 117

37. Index of Stratigraphic Section Locality Maps. . 119

38. Locality Maps of Stratigraphic Sections . . . 120

39. Third Creek Stratigraphic Section ....... 121

40. Wanderers Peak Stratigraphic Section. . . . . 122

41. Promontory Park Stratigraphic Section . . . . 123

42. S 562A Stratigraphic Section ......... 124

43. Big Eddy Stratigraphic Section ........ 125

44. Cripple Creek Stratigraphic Section . . . . . 126

45. Ripplebrook Stratigraphic Section . . . . . 127

46. Canyon Creek Stratigraphic Section . . . . . 128

47. Big Creek Stratigraphic Section . . . . . . . 129

48. Whale Head Stratigraphic Section ....... 130

49. Memaloose Road Stratigraphic Section ..... 131 


\section{CHAPTER I}

\section{INTRODUCTION}

The primary purpose of this study was to produce a geologic map of all major exposures of Columbia River Basalt that occur within the drainages of the clackamas River and its tributaries (above North Fork Dam). Identification and mapping of subunits within the Columbia River Basalt Group and the resolution of structure thereby is the guiding objective within the context of this general purpose.

It is the clarification of this stratigraphic sequence that has prevented the accomplishment of such studies in the past. Wells and Peck (1961) and Peck, et al. (1964) mapped the outline of the Columbia River Basalt in this area on their small scale regional maps, but were hampered in the effort to identify structures by limited stratigraphic resolution. The state of the art relative to Columbia River Basalt stratigraphy was essentially undeveloped at that time and techniques for identifying the now well-known subunits simply did not exist. This study therefore represents the logical next step in the geologic evaluation of the clackamas River area.

The clarification of the stratigraphic sequence within the basalts of the Columbia River Group has the immediate fringe benefits of clarifying structural specifics such as 
faults, folds, and flexures as well as more closely defining differences between older and younger formations. The latter has been a somewhat controversial problem in past mapping efforts due to the lithologic similarity between the units immediately below and above the Columbia River Basalts. This is particularly evident beyond the southern extent of the basalt where these formations are in contact with one another and are distinguished with difficulty.

On a less local scale, the clarification of the columbia River Basalt stratigraphy in this area makes it possible to make regional correlations with a high degree of confidence. This can be done largely as a result of the remarkable compositional uniformity of flood basalts, whose episodic advent was essentially instantaneous over the entire area of their occurrence from the standpoint of geologic time. This study will provide one more piece in the puzzle from the standpoint of comprehending the structural environment that existed in the ancient Cascades, whereby columbia River Basalts were permitted to cross into western Oregon and ultimately extend as far as the present oregon coast. A flood basalt sequence is particularly well-suited for this type of analysis where accurate correlation with other study areas will ultimately be involved.

This type of structural and stratigraphic mapping is very useful for the development of hydroelectric and geothermal energy resources; for the understanding of existing and potential landsliding; for the location of zones of 
hydrothermal mineralization; and for the recognition of areas of potential seismicity. Thus, the pragmatic aspects of this study are many and far-reching, and are affected intimately by the structural fabric of the area.

\section{Geographic Setting}

The location of the thesis area is within the western flanks of the Cascade Range of oregon, approximately 66 kilometers southeast of Portland and 77 kilometers southwest of Mount Hood (Figure 1). The approximately 740 square kilometer area includes the gentle constructional volcanic slopes of the High Cascade Range on the east and the more maturely dissected Western Cascade Range on the west. Large quantities of orographic rainfall $(95.5 \mathrm{~cm} . /$ year) feed a welldeveloped drainage network that has produced a high degree of topographic relief and a generally rugged wooded terrain.

The Columbia River Basalt in the map area appears most. prominently where it has been exposed by channel incision of the clackamas River and its major tributaries. The drainages involved include, from west to east, the North Fork of the Clackamas River, the South Fork of the clackamas River, Memaloose Creek, Fish Creek, Roaring River, the South Fork of Roaring River, and the oak Grove Fork of the clackamas River (Figure 2). Important geographic reference points include North Fork Reservoir and Dam, 3.5 kilometers east of Estacada on the Clackamas River which delineates the western boundary of the map area; Lake Harriet, 40 kilometers east 


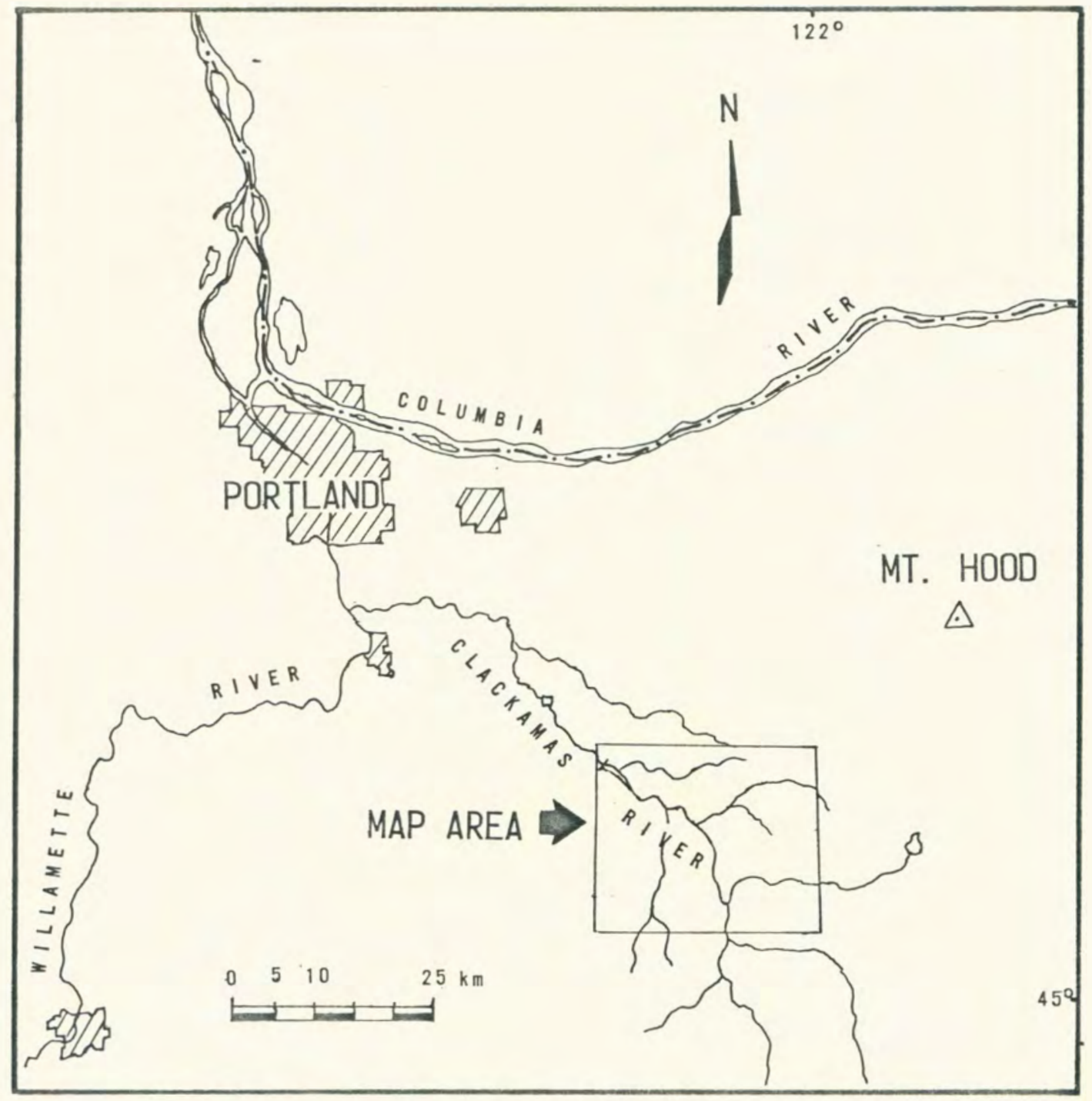

FIGURE 1. LOCATION MAP FOR THE CLACKAMAS RIVER STUDY AREA 


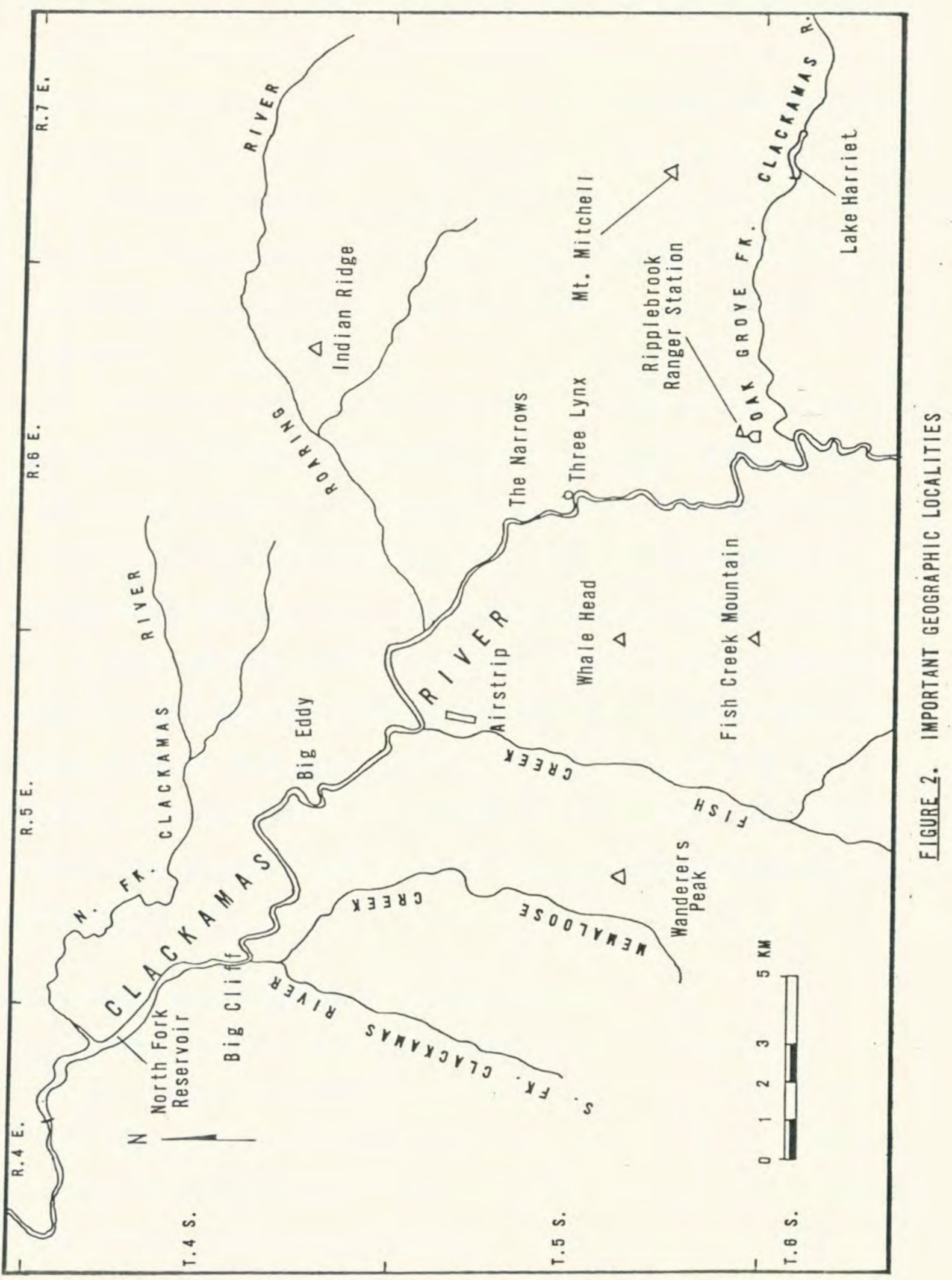


of Estacada on the Oak Grove Fork of the Clackamas River, which delineates the eastern map boundary; Fish Creek Mountain and Wanderers Peak, which define the approximate southern boundary approximately $10 \mathrm{kilometers} \mathrm{south} \mathrm{of} \mathrm{the}$ main Clackamas River. Other key reference points, from east to west, in the main Clackamas River canyon are Big Cliff, Big Eddy, the Narrows, Three Lynx and Ripplebrook Ranger Station.

Hydroelectric facilities exist at North Fork reservoir and at the Lake Harriet/Three Lynx complex. The latter involves a diversion and pipeline system from Lake Harriet on the Oak Grove Fork of the Clackamas River to Three Lynx on the main clackamas River where a powerhouse is located. Logging and associated road construction is widespread over most of the area but is prohibited in and around the Roaring River drainage, making it the least accessible of the major tributaries. Roads built as a result of logging operations greatly facilitated mapping in all other parts of the area.

Procedure and Methods of Investigation

This project was approached in four phases: (1) an initial reconnaissance phase, during which the upper and lower contacts of the Columbia River Basalt were sought along with preliminary identification of field-recognizable units; (2) a detailed data collection phase, during which stratigraphic sections were measured and samples collected; 
(3) an analytical phase, during which detailed geochemical studies were conducted; and (4) a post-analytical field mapping phase, during which all identified units were mapped, correlated and subjected to detailed structural scrutiny. Phases (1), (2) and (4) were accomplished primarily during the summers of 1976 and 1977 and involved a total of approximately 34 man-days. Geochemical analysis and petrographic studies of phase (3) were conducted during the spring of 1977.

The reconnaissance phase was an important step in assessing the best means to accomplish data collection. It became increasingly evident that, despite shallow dips and an apparent absence of major structures in the main river canyon, it would be difficult to compile an accurate stratigraphic section along the main highway at or near road level. General field characteristics or gross jointing aspects of flows were not initially reliable criteria for correlating across covered intervals with any degree of confidence. The similary of flows in the main river canyon is more fully explained in Chapter III, where the characteristics of the Grande Ronde Basalt are discussed in detail. A special effort was made to identify localities where vertically extensive exposures or sequences of flows could be examined by direct ascent of the canyon walls, with minimal cover hampering the effort.

Cross-canyon oblique photography was used extensively to identify potential sections and to orient traverses. 
Photographic filtration techniques were used to enhance contrast between rock and forest as well as to reduce the loss of resolution due to haze. Photo mozaics were employed frequently to provide an expanded perspective in excess of that possible with available lenses. Photographic enlargements were carried in the field whenever possible when measuring and describing sections.

A total of 16 stratigraphic sections with four or more flows were examined and described in detail with particular attention being paid to jointing character, degree of vesiculation, nature of contacts, pillow complexes, thickness of flows, interbedded units, lithologic character (where useful) and magnetic polarity. The latter was determined using a portable (model 70) fluxgate magnetometer, whereby a minimum of three samples were tested on location in all cases. Application of this instrument was restricted in nearly all instances to the chilled tops of flows. Alternately, flow bottoms or non-brecciated pillow complexes were used. The common denominator of each of the above applications is the quality of rapid cooling which was evidenced by the presence of glass.

Rock sampling was accomplished on all flows and flow units within a given section. In some instances, both colonnade and entablature were sampled. Flow centers were sampled whenever possible, and great care was exercised in acquiring unweathered samples for analysis.

Trace element geochemical studies were conducted on 
five measured sections during the spring of 1976 employing Instrumental Neutron Activation Analysis (INAA). Sections to be analyzed were selected on the basis of completeness and geographic location in order to provide maximum stratigraphic control over the map area. The Reed College Triga Mark 1 nuclear reactor and high resolution Ge(Li) x-ray detector and multi-channel analyzer were utilized, as well as computer facilities at Portland State University. A general discussion of INAA Procedures is included in Appendix C. Major oxide analyses by x-ray fluorescence spectroscopy were conducted by Dr. Peter Hooper at Washington State University on one complete Clackamas River section, excluding the Frenchman Springs Member. Petrographic studies were done on one complete section and thereafter were done where necessary or particularly useful for correlation purposes.

The results of the above studies made it possible to identify various specific chemical types within the columbia River Basalt Group. This knowledge, coupled with previous observations regarding overall flow characteristics, made it possible to recognize flow groups and in some instances individual flows in the field. 


\section{REGIONAL GEOLOGY}

The Columbia River Basalt Group is a thick sequence of tholeiitic plateau or "flood basalts" that covered large areas of Oregon, Washington and Idaho during middle to late Miocene time (Figure 3). These flows are 6 to 16.5 million years old (Watkins and Baksi, 1974; McKee, et al., 1977) and thus constitutes the youngest subaerial flood basalt accumulation on earth. The geometry of the columbia plateau flood basalts is that of a crude plano-convex lens that ranges in thickness from 1500 meters at its center to zero where it laps up against the foothills of the ancient Cascades mountain range to the west.

Swanson, et al. (in press) refers to the Imnaha, Picture Gorge and Yakima Basalt subgroups within the Columbia River Basalt Group. It is the Yakima Basalt subgroup that is of primary interest to this study, in that only yakima Basalts have thus far been recognized in western oregon. There are three formations defined within the Yakima Basalts: the Grande Ronde Basalt, the Wanapum Basalt and the Saddle Mountains Basalt (Figure 4). These correspond, respectively, to the Lower, Middle and Upper Yakima Basalts of Wright, et al. (1973). The Grande Ronde and Wanapum Basalts are of particular interest to this study since the Saddle Mountains 


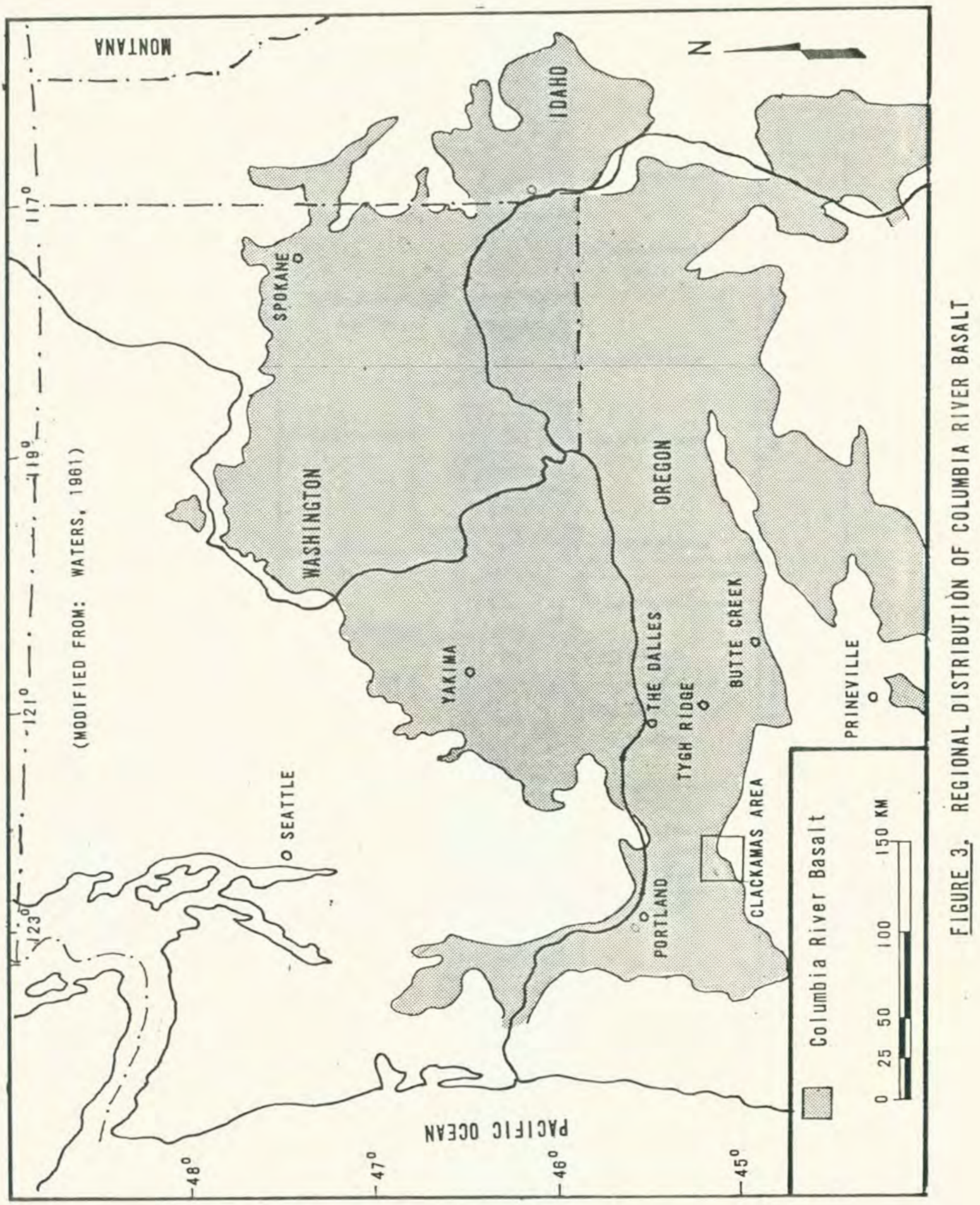


Stratigraphic terminology in the Yak1ma-Ellensburg-Vantage area. Names used informally are shown in lower case.

(MODIFIED FROM: BENTLEY, 1977)

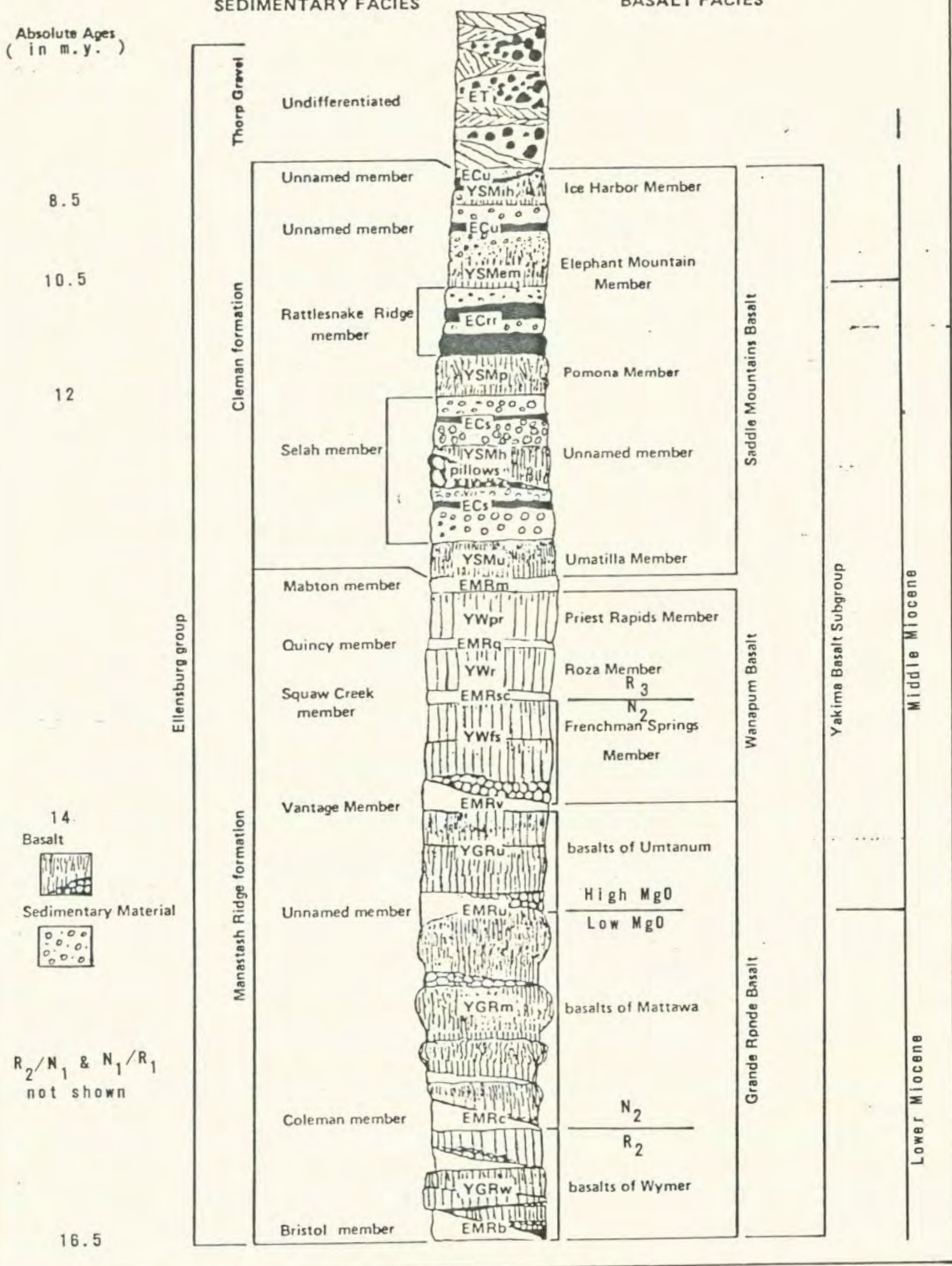


Basalts were apparently excluded from this part of the western Cascades.

\section{Grande Ronde Basalt}

The Grande Ronde Basalt is the most voluminous, laterally extensive and oldest formation within the Yakima Basalt Subgroup. It has been estimated that this formation constitutes as much as $80 \%$ by volume of the Yakima Basalt (Swanson \& Wright, 1978) with local thicknesses in the central plateau of up to 1200 meters (Bentley, 1977). Thicknesses in peripheral areas generally range from 150 to 500 meters, with other Yakima Basalts sometimes totally absent. As many as 23 individual flows have been recognized within the Grande Ronde Basalt in some localities.

Differentiating between individual flows within this thick accumulation has thus far been done only with great difficulty. This is due largely to the fact that, at the present state of the art, these flows are lithologically and petrographically non-distinctive. Flows of the Grande Ronde Basalt can best be characterized as fine-grained, aphyric, dense black basalts. Geochemical and paleomagnetic subdivisions (Swanson, et al., in press) have been recognized and are discussed more fully in chapter III. However, there is no generally reliable field criterion for distinguishing individual flows except where physical characteristics are locally distinctive. 


\section{Vantage Member}

The Vantage Member of the Ellenburg Formation was deposited during a period of time between flood basalt episodes that was perhaps a million years in duration. Sufficient time elapsed for widespread sedimentary units to accumulate and for the uppermost basalt flows to be weathered significantly. Subsequent basalt outpourings were distinct chemically from the thick underlying Grande Ronde section. Thus, this stratigraphic interval may be occupied by the Vantage Member (an interbed of variable sedimentary composition) or by a weathered zone, either of which separates basalts having distinctive chemical and physical characteristics. It is without question the most distinctive stratigraphic marker in the western Columbia plateau.

\section{Wanapum Basalt}

The wanapum basalts are physically and chemically distinct from the Saddle Mountains and Grande Ronde basalts of the Yakima Basalt Subgroup. They have higher $\mathrm{Ti}$ and Fe concentrations than do the other two formations (Seims, et al., 1974), as well as characteristic lithologies (Mackin, 1961; Bingham and Grolier, 1966). Wanapum basalts are generally coarse-grained, may or may not be plagioclase phyric and have varied magnetic polarities. Four members have been named including, from oldest to youngest, the Eckler Mountain, Frenchman Springs, Roza and Priest Rapids Members (Swanson, et al., in press). 
The differences between these three members are petrographic, lithologic and paleomagnetic and need not be discussed in detail here since these characteristics are well-documented by previous workers. Thus far, only the Frenchman Springs Member has been clearly identified west of the Cascade Range (Beeson, et al.,1976a) and apparently preceded major uplift since later Wanapum members were excluded except as intracanyon flows. It is by far the most voluminous of the Wanapum basalts in the Columbia Plateau, exceeding the Eckler Mountain, Roza and Priest Rapids members combined. Flows number as many as ten in the central plateau (Bentley, 1977) and as many as five west of the Cascades (Beeson, et al., 1976a). Thus, the Frenchman Springs Member, like the Grande Ronde Basalt, is of primary importance to this study. 


\section{STRATIGRAPHY}

The Columbia River basalts in the clackamas River clearly fall within the general Grande Ronde and Wanapum Basalt chemical types. The Grande Ronde Basalt sequence can be further divided into five subtypes based upon both geochemistry and paleomagnetics, including, in descending stratigraphic order, a high Mgo sequence with normal polarity, a low Mgo sequence with normal polarity, a Prineville sequence with reversed polarity, a low MgO sequence with reversed polarity, and a low Mgo sequence with normal polarity (Figure 5). The Wanapum basalts can be more specifically identified as Frenchman springs Member flows with two consistent subunits apparent within the clackamas River area. These include, in stratigraphic order, a three to five flow sequence having locally abundant plagioclase phenocrysts, a one to two flow sequence of flows having rare plagioclase phenocrysts and at least one additional flow having abundant phenocrysts (Figure 5). The Wanapum and Grande Ronde Basalt will now be discussed in greater detail.

\section{Grande Ronde Basalt}

Variation in trace element and major oxide concentrations within the pre-Vantage Columbia River Basalt flows is 


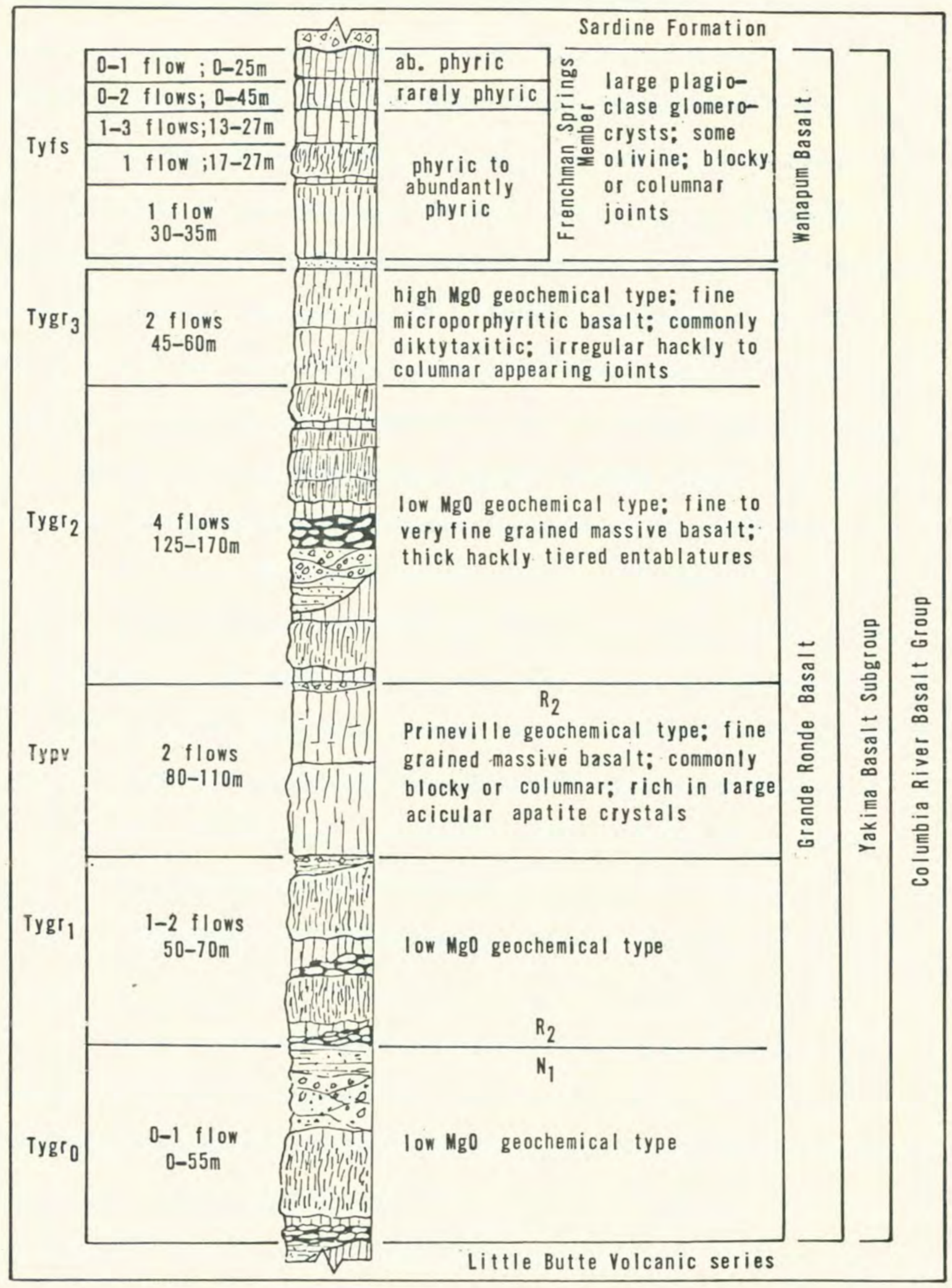

FIgURE 5. GENERALIZED StratigraphIC COLUMN FOR COLUMBIA RIVER baSALt IN THE ClaCKaMAS RIYER AREA 
significant enough to warrant identification of three distinct geochemical types in the Clackamas River area. These include high and low Mgo Grande Ronde Basalt variants such as those documented elsewhere in the western part of the Columbia River Plateau (Wright, et al., 1973; Nathan and Fruchter, 1974; Taylor, 1976; Atlantic Richfield Hanford Company, 1976; Beeson, et al., 1976a and Beeson, et al., 1976b) and the Prineville type previously described by Uppuluri (1974) near Prineville Dam in north central oregon. High Mgo/Low Mgo Grande Ronde Basalt types. A geochemical horizon marked primarily by a sharp increase in the concentration of MgO was recognized in the upper part of the Grande Ronde Basalt sequence by Wright, et al. (1973). It has subsequently been recognized over much of the western Columbia plateau and has proven to be a useful stratigraphic marker. The Grande Ronde basalts of the clackamas River area clearly show this chemical break in both major oxide and trace element concentrations.

In addition to the prominent Mgo increase, there are lesser variations in other major oxides that, when taken collectively, produce a recognizable and correlatable pattern. Increases occur in $\mathrm{Al}_{2} \mathrm{O}_{3}$ and $\mathrm{CaO}$ while $\mathrm{SiO}_{2}, \mathrm{FeO}, \mathrm{Na}_{2} \mathrm{O}, \mathrm{K}_{2} \mathrm{O}$, $\mathrm{TiO}_{2}$ and $\mathrm{P}_{2} \mathrm{O}_{5}$ decrease noticeably. Of the ten major oxides determined, only Mno shows little or no change across this geochemical break. The significance of these collective changes can be readily seen when average values for the 
upper four low MgO flows and for all high Mgo flows of the Clackamas River are compared to the regional averages of Wright, et al. (1973) and Swanson, et al. (in press), Table I. Not only are the concentrations closely comparable allowing for relative error, but the sense of elemental variation between chemical types is similar in every case. Trace element variation is no less germane to the definition of the high Mgo/low Mgo geochemical horizon than are major element variations. Minor elements Ce, Eu, Th, La, and Sm all tend to have concentrations that are noticeably lower in the high Mgo basalt type. Of these, Th, La, and Sm prove to be most significant or diagnostic considering relative error. Values of high Mgo basalts do not overlap those of the low Mgo basalts when analytical uncertainty is considered. Similarly, Co and Sc have concentrations that are noticeably higher in the high Mgo basalts with Sc proving to be most significant due to its very low error. These variations, as in the case of major oxides, compare favorably to concentrations observed in the Columbia Plateau and elsewhere.

The Tygh Ridge stratigraphic section of Nathan and Fruchter (1974) contains this chemical horizon, as do the West Linn (Beeson, et al., 1976a) and Deschutes River sections (Beeson, personal communication). These localities are shown in Figure 3, and Table II contains a list of averaged concentrations for trace elements that are most diagnostic of the high Mgo/low Mgo geochemical horizon. Each of these 


\section{TABLE I}

COMPARISON OF CLACKAMAS RIVER AND COLUMBIA PLATEAU MAJOR OXIDE CONCENTRATIONS FOR HIGH MgO/LOW MgO GEOCHEMICAL TYPES

Clackamas River H. $\mathrm{MgO}^{2 /} \mathrm{L} \cdot \mathrm{MgO}^{4 /}$

C.R.B. Averages* H. $\mathrm{MgO}$ L. $\mathrm{MgO}$

$54.09 \quad 54.98$

14.33

13.76

11.42

12.30

4.90

3. 38

8.72

7.11

2.84

3.27

1.17

1. 78

1.78

.31

2.20

.39

.20
C.R.B. Averages** H. MgO L. MgO $53.78 \quad 55.94$ $14.45 \quad 14.04$ $11.35 \quad 11.77$

5.253 .36

$9.07 \quad 6.88$

$2.83 \quad 3.14$

1.051 .99

$1.78 \quad 2.27$

$.28 \quad .43$

.19

.19

n/ number of flows averaged

* Wright, et al. (1974)

** Swanson, et al. (in press) 
兄

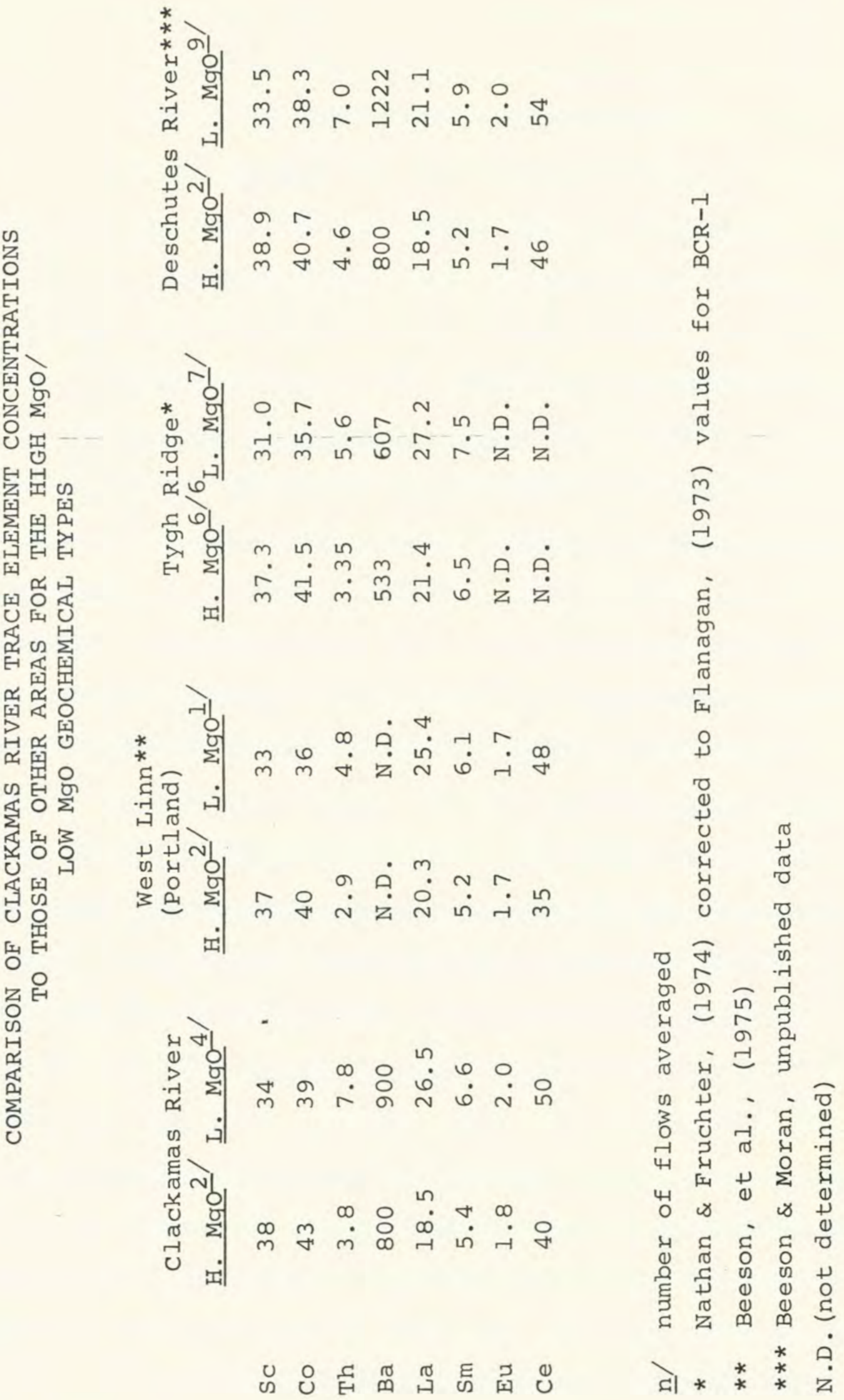


stratigraphic sections clearly shows the same pattern of elemental variation that is shown in the clackamas River sections. Absolute abundance also corresponds closely.

The high Mgo/low Mgo geochemical horizon is thus a widely recognized and well-documented stratigraphic feature of the Grande Ronde Basalt that is also identifiable within the Clackamas River area. Both trace element and major oxide analysis are effective tools for this determination. Prineville Geochemical Type. The Prineville basalt type was first recognized and described by Uppuluri (1973) in central oregon. Both trace element and major oxide abundances were noted to fall outside of the range of values commonly associated with lower and middle Yakima basalts (also picture Gorge). This chemical type has been shown to be contemporary with the low Mgo Grande Ronde Basalt by Nathan and Fruchter (1974). A flow having trace element concentrations indistinguishable from those of the Prineville was found interbedded within a low Mgo Grande Ronde sequence at Buck Creek, 120 kilometers north-northeast of the type locality at Prineville Dam. This flow, now named the "Buckhorn Flow", was previously noted by Wright, et al. (1973) and Brock and Grolier (1973) to have anomalously high $\mathrm{P}_{2} \mathrm{O}_{5}$ concentrations relative to other Columbia River Group flows in that area. Nathan and Fruchter also identified a Prineville flow within the Tygh Ridge section $130 \mathrm{kilo-}$ meters north-northeast of the type locality. This evidence firmly establishes the time-stratigraphic equivalency of the 
Prineville basalts and the low Mgo Grande Ronde basalts and is the basis for the tentative inclusion of this unit within the Grande Ronde Basalt in the proposed Revisions to stratigraphic Nomenclature by Swanson, et al. (in press). A detailed discussion of the geochemical differences between the Prineville flows and other Columbia River Basalt Group types can be found in Uppuluri (1973, 1974).

Flows of the Prineville chemical type are also present in the clackamas River drainage and are easily distinguished by both major oxide and trace element abundance data. This geochemical type can be distinguished on the basis of seven trace elements including $\mathrm{Eu}, \mathrm{Ce}, \mathrm{Ba}, \mathrm{Sm}, \mathrm{Co}, \mathrm{Sc}$, and $\mathrm{Th}$. of these, Th is intermediate between the high and low Mgo Grande Ronde values and co is distinctly lower than both. The remaining five elements are present in abundances that are noticeably higher with only ce having reduced significance due to relative error. It should be noted that Th also overlaps Grande Ronde values when analytical uncertainty is considered. Four elements, Sm, Eu, Ba and Co, are particularly striking as differentiators.

$\mathrm{Ba}$ has concentrations in the Clackamas River flows that are higher by a factor of two to three than any of the other Columbia River Group flows in the area. The only comparable value anywhere in the columbia River basalts is that of the Umatilla Member of the Saddle Mountains Basalt which has Ba concentrations that are slightly higher. Co, conversely, has abundances in the clackamas River flows that 
are 30-37\% lower than all other flows in the section. It is in fact lower than in any other chemical type in the entire Columbia River Basalt Group. Eu, like Ba, has concentrations that are greater than the other flows present by a factor of two to three. It is approximately equal to the Umatilla type and exceeded only by the youngest of the two Ice Harbor flows in the saddle Mountain Basalt. Sm has values that range between $10 \%$ and $85 \%$ higher than the other types present in the clackamas area depending upon the basalt type being compared. Prineville flows have Sm concentrations that are $30 \%$ to $60 \%$ higher than $10 \mathrm{w} \mathrm{MgO}$ and $80 \%$ to $85 \%$ higher than high MgO Grande Ronde basalts. Wanapum basalts tend to have higher and more varied Sm values than do Grande Ronde basalts, but still range between $10 \%$ and $50 \%$ lower than Prineville values.

The abundance of all four of the above-mentioned trace elements in the clackamas River "Prineville" flows are within analytical error of Uppuluri's values for the type locality at Prineville Dam as well as for the Buckhorn Flow of Nathan and Fruchter (1974) at Butte Creek (Table III). Correlation is better with the Buckhorn Flow which is remarkably similar chemically. It should be noted, however, that the clackamas River Prineville flows have reversed paleomagnetic polarity while the Buckhorn Flow is normally polarized based upon fluxgate data. Uppuluri's PD 7 through PD 13 are most similar to the Clackamas River flows in trace element character and were accordingly averaged in Table III. 


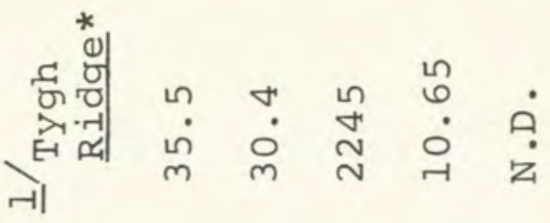

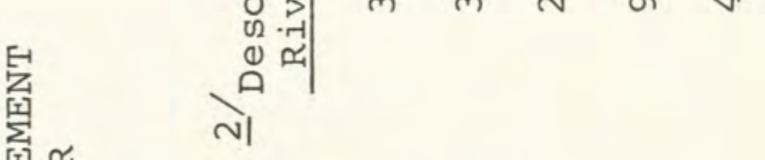

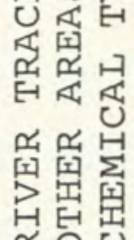

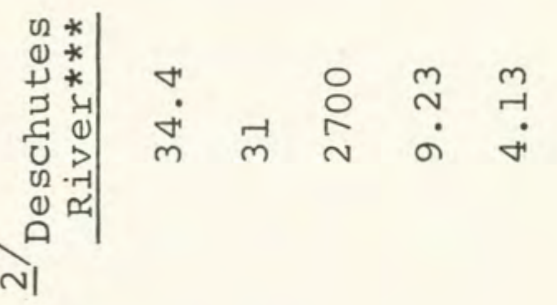

검

되 더 되

돠 थै त्र

出 तो

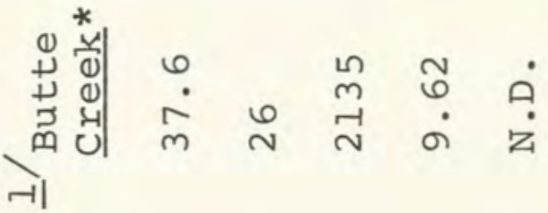

H 苗

四四

所 岁毕

近国

近 导吕

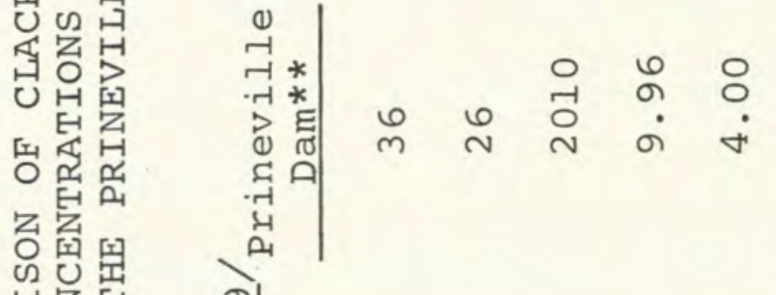

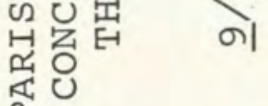

$\sum_{0}^{\infty}$

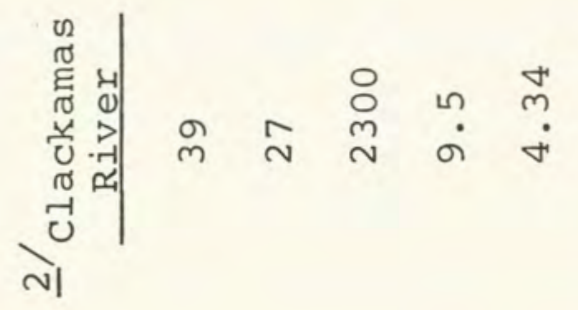

4
0
4

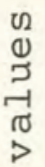

m

ने

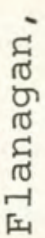

+

\begin{tabular}{l} 
¿ \\
+ \\
0 \\
0 \\
\cline { 1 - 1 } \\
0 \\
0 \\
0
\end{tabular}

ד

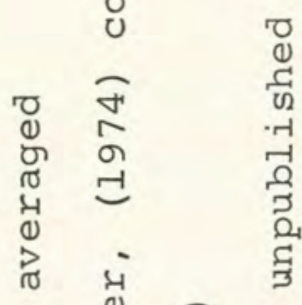


Distinctions that can be recognized in the major oxide analyses include primarily high $\mathrm{P}_{2} \mathrm{O}_{5}$ and low $\mathrm{SiO}_{2}$. Lesser differences occur in $\mathrm{TiO}_{2}, \mathrm{MnO}, \mathrm{MgO}$ and $\mathrm{CaO}$. The $\mathrm{P}_{2} \mathrm{O}_{5}$ concentrations in the Clackamas River Prineville flows are three to four times greater than other Grande Ronde types making this the most obvious major element difference. $\mathrm{SiO}_{2}$ tends to be $2 \%$ to $4 \%$ lower in the Prineville type than in either the high Mgo or low Mgo types. $\mathrm{TiO}_{2}$ is only slightly higher than the low Mgo type but is distinctly higher (approximately 40\%) than the high Mgo type. Mgo, Mno and Cao occur in concentrations that are intermediate between the high and low Mgo chemical types and are less reliable indicators in terms of relative error than are $\mathrm{P}_{2} \mathrm{O}_{5}, \mathrm{SiO}_{2}$, and $\mathrm{TiO}_{2}$. The Clackamas River values compare remarkably well with major oxide analyses from both the type locality near Prineville Dam and with the Buckhorn Flow at Butte Creek (Table IV).

Magnetostratigraphy. There are two paleomagnetic reversal events within the Clackamas River Columbia River basalts that divide the section into three polarity units (Figure 5). The first has normal polarity and includes the lowest exposed flow in the stratigraphic section; the second is a reversed sequence consisting of three to four flows capped by the Prineville geochemical unit; and the third includes the remainder of the basalt section overlying the Prineville. This uppermost normally polarized unit encompasses the upper low MgO Grande Ronde flows in addition 


\section{COMPARISON OF CLACKAMAS RIVER MAJOR OXIDE CONCENTRATIONS WITH OTHER AREAS FOR \\ THE PRINEVILLE GEOCHEMICAL TYPE}

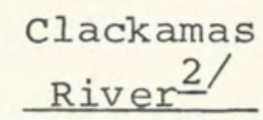

$\mathrm{SiO}_{2}$

$\mathrm{TiO}_{2}$

MgO

Mno

$\mathrm{CaO}$

$\mathrm{P}_{2} \mathrm{O}_{5}$
51.0

2.64

4.60

.24

8.15

1.20
*Butte Creek $\stackrel{\text { I/ }}{ }$ 50.6

2.69

4.55 .24

7.87

1.40

n/ number of flows averaged

* Nathan \& Fruchter, (1974)

** Uppuluri, (1973) 
to all of the high Mgo and Frenchman Springs flows. The two reversal events are considered to be equivalent to the $\mathrm{N}_{1} / \mathrm{R}_{2}$ and $\mathrm{N}_{2} / \mathrm{R}_{2}$ paleomagnetic horizons recognized by previous workers elsewhere in the Columbia Plateau (Figure 4).

The paleomagnetic character of the uppermost Prineville flow is not completely straight-forward from the standpoint of natural remanent magnetic polarity as determined with portable fluxgate magnetometers. In the eastern two-thirds of the study area, this flow is often capped by a sedimentary interbed and was found to be consistently reversed when tested at the chilled upper margin of the flow (Figure 36, pg.117; Figure 44, pg.126). In the western one-third of the area, the interbed is more intermittent and is absent at the majority of outcrops examined. The excellent exposures at Big Cliff (Figure 2) reveal an example of this phenomenon with the Prineville/low Mgo Grande Ronde contact consisting of a narrow vesicular zone with no interbed present. At this locality and at other similarly disposed sites, the upper chilled margin consistently yielded normal readings. Closer examination of the Big Cliff locality yielded some surprising results. A vesicular chilled zone extends diagonally across the outcrop, ultimately merging with the upper Prineville contact. This appears to be either a large area of subducted flow top or possibly a ramp structure (Figure 6). Geochemical analyses both above and below this vesicular zone yielded trace element concentrations of the Prineville chemical type (samples BCLF-1 \& 2, Appendix C). 


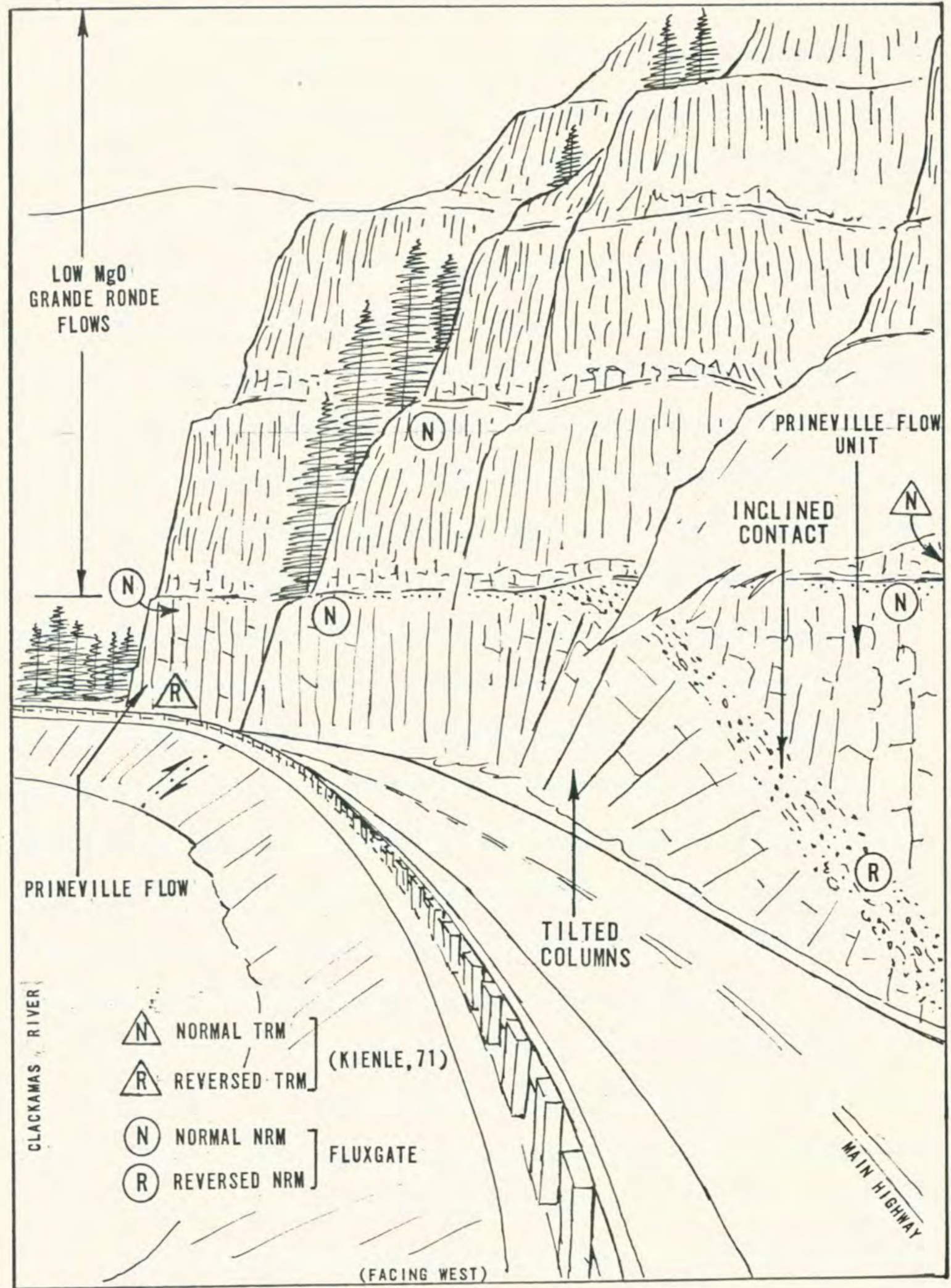

FIgURE 6. PALEOMAGNETIC SAMPLE LOCALITIES AT BIG CLIFF 
Paleomagnetic studies of the vesicular zone itself yielded consistently reversed fluxgate readings, contradicting the normal readings obtained at the flow top (Figure 6). This presents a serious dichotomy regarding the interpretation of the local magnetostratigraphy.

Some clarification is provided by the regional work of C. F. Kienle (1971), wherein numerous sites were drilled and spinner demagnetized, including two flows at the Big Cliff site. His results clearly show the Prineville flow at Big Cliff to be reversed while the next flow above (low Mgo) is normal. Kienle's major oxide geochemical data reflect the Prineville/low Mgo horizon, with distinctly higher Mgo, CaO, $\mathrm{TiO}_{2}, \mathrm{MnO}$ and lower $\mathrm{SiO}_{2}$ in the lower flow than in the flow above. The two flows are therefore Prineville and low Mgo Grande Ronde respectively, based upon similar variation observed in the major oxide concentrations of the control section described previously (Appendix D). This confirms the stratigraphic equivalency of Kienle's flows with the flows in question and strongly indicates a reversed magnetic polarity for the Prineville flow at Big Cliff.

A possible explanation for the ambiguity observed in the paleomagnetics of the upper Prineville flow at Big Cliff and at other localities involves the presence or absence of interbedded sediment at the uppermost contact. Such a layer could partially insulate the underlying flow from reheating by the overlying flow, and thus prevent thermal remagnetization of the flow top. Flows not insulated by an interbed 
would have a thin upper margin that could be subjected to temperatures in excess of the Curie temperature. The Prineville flow at Big cliff has an unusually thin chilled vesicular zone at its upper contact that is commonly less than two meters thick. Therefore, it is possible that the flow top could have been thermally remagnetized by the heat of the subsequent flow.

Petrography. The Yakima basalts in the clackamas River area, like those elsewhere, have certain characteristics that set them apart from other units within the Columbia River Basalt Group. They generally contain $20 \%$ to $40 \%$ glass, usually tachylyte, in the non-chilled parts of the flow. This characteristic, according to waters (1961), sets them apart from the older nearly holocrystalline Picture Gorge basalt and was one of the reasons for his initial two-fold division of the Columbia River Basalt. Two other characteristics of the Yakima Basalt cited by Waters, and observable in the clackamas River basalts, are plagioclase of approximately $\mathrm{An}_{50}$ and the near absence of olivine.

Other workers have conducted detailed petrographic studies including Schmincke (1964, 1967), Swanson (1967) and Diery (1969), involving determination of norms and the examination of other specific mineralogic characteristics. These results have proven useful in only the broadest sense for subdividing the basalts into pervasive subunits. For this reason, similar petrographic data is not presented here. 
Those characteristics that are considered useful as local identifiers are listed in Table $\mathrm{V}$ and will now be discussed for the Clackamas River Grande Ronde basalts.

In general, the Grande Ronde flows have a groundmass that is finer grained than that of the Wanapum Basalt flows. Grain size differences within the Grande Ronde itself often occur between the high and low Mgo subunits where the high Mgo flows are microporphyritic, giving them a coarser aspect than the low Mgo flows. Small phenocrysts, or microphenocrysts, are not uncommon in Grande Ronde flows. However, there is a notable increase in their number within the high Mgo flows relative to flows immediately underlying them. High Mgo flows also tend to be diktytaxitic whereas low Mgo flows generally are not.

The Prineville flows, as their unusual chemistry would suggest, are more consistently identifiable petrographically than the high Mgo subunit. These flows have a general tendency toward flow alignment of crystals into a pilotaxitic texture, whereas others tend not to be flow aligned. The most distinctive characteristic, however, is the presence of anomalously long, acicular apatite crystals that occur in great abundance in all thin sections. It is the size of these crystals relative to the size of groundmass grains that is the key identifier. Acicular apatite occurs in many other parts of the section but is relatively finer grained by a factor of three to four. The apatite crystals are a direct reflection of a $\mathrm{P}_{2} \mathrm{O}_{5}$ content that is about three times 


\begin{tabular}{|c|c|c|c|c|c|}
\hline \multirow{4}{*}{ 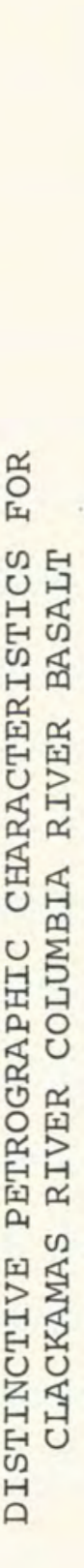 } & 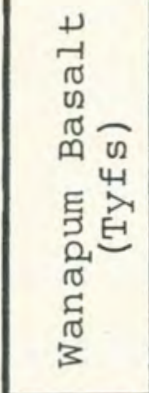 & $\begin{array}{l}0 \\
0 \\
0 \\
4 \\
\pi \\
0 \\
0 \\
1 \\
02 \\
0 \\
0\end{array}$ & i & 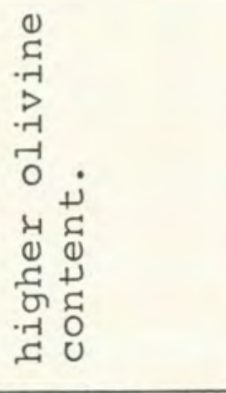 & 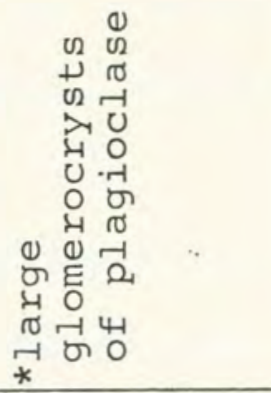 \\
\hline & 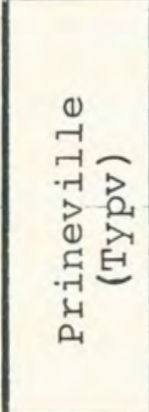 & $\begin{array}{l}0 \\
0 \\
0 \\
\pi \\
0 \\
0 \\
0 \\
u \\
0 \\
0 \\
0 \\
0 \\
-1\end{array}$ & 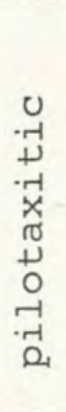 & 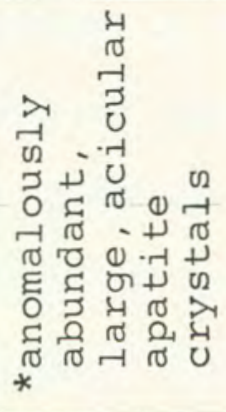 & I \\
\hline & 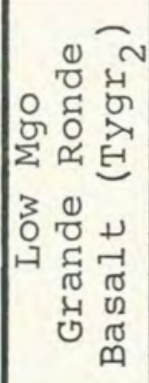 & $\begin{array}{l}0 \\
0 \\
y \\
0 \\
0 \\
0 \\
0 \\
+1 \\
02 \\
0 \\
0 \\
-1\end{array}$ & i & I & i \\
\hline & 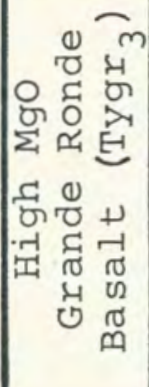 & 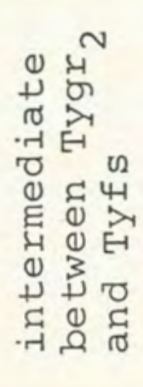 & 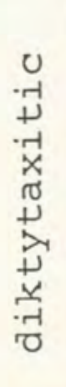 & i & 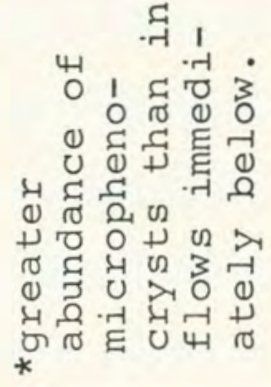 \\
\hline
\end{tabular}

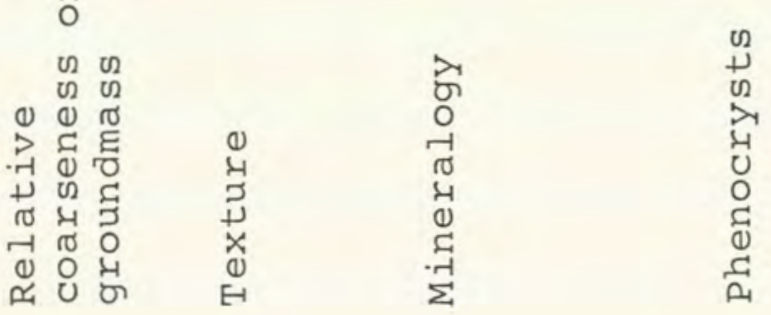


higher in Prineville flows than it is in other flows in the section. They appear to be late forming and are most abundant in and around patches of glass and along the edges of partially formed crystals of plagioclase.

The unique petrographic character of the Prineville flows is not restricted to the clackamas River area. Thin sections of three Prineville flows in the Deschutes River area were clearly identified on the same basis. Uppuluri (1973) also observed that flow aligned microlites and unusually abundant needle-like apatite crystals were common in virtually all flows in the Prineville Dam type section. Physical Characteristics. The jointing character of flows within the Yakima basalts varies in a more or less distinctive manner between some broadly different chemical groups. Diery $(1967,1969)$, in his description of the Columbia River basalts in the Yakima River Canyon, mentioned the general difference between the jointing character of the Pre-Vantage (Grande Ronde) and Post-Vantage (Frenchman Springs and Roza) flows. The Grande Ronde flows were described as having well-developed colonnade and entablature structures, with the latter composing $50 \%$ to $90 \%$ of the thickness of an individual flow. The Frenchman Springs flows were described as having jointing that consisted of either cross-jointed columns or large irregular blocks. These characteristics are in fact widely recognized as differences between the pre-Vantage and post-Vantage flows (Swanson, et al., in press) and apply equally well to the 
Clackamas River area.

The low Mgo Grande Ronde basalts in the area of this study generally have thin basal colonnades and blocky bases that in some locations shows local platiness. The hackly entablatures of these flows are the dominant jointing feature and constitute $60 \%$ to $95 \%$ of an individual flow (Figure 23, pg. 104). Fan jointing is locally present but is not a consistent identifying feature. Pillow complexes occur locally above sedimentary interbeds but, like fan jointing, are not consistent identifying features due to their intermittent nature. Contrary to the suggestion of Diery (1969),, the presence of a thick entablature relative to the colonnade does not appear to be a function of flow thickness, at least not in the Clackamas River area. Well-developed entablatures can be observed in low Mgo Grande Ronde flows, even where they thin to a feather edge near the onlap with the Little Butte Volcanic Series. The entablatures dominant characteristic applies equally well to both the reversed and normal low Mgo Grande Ronde subunits.

The high Mgo Grande Ronde flows can be locally confused with low Mgo flows if stratigraphic context is not considered. However, these flows often display a recognizably different jointing sequence from that seen in the underlying flows. The jointing of the high Mgo flows in the clackamas River area more closely resembles that of the Frenchman Springs than it does that of the low Mgo Grande Ronde (Figure 7). The reason for this is the alternating irregular zones of 


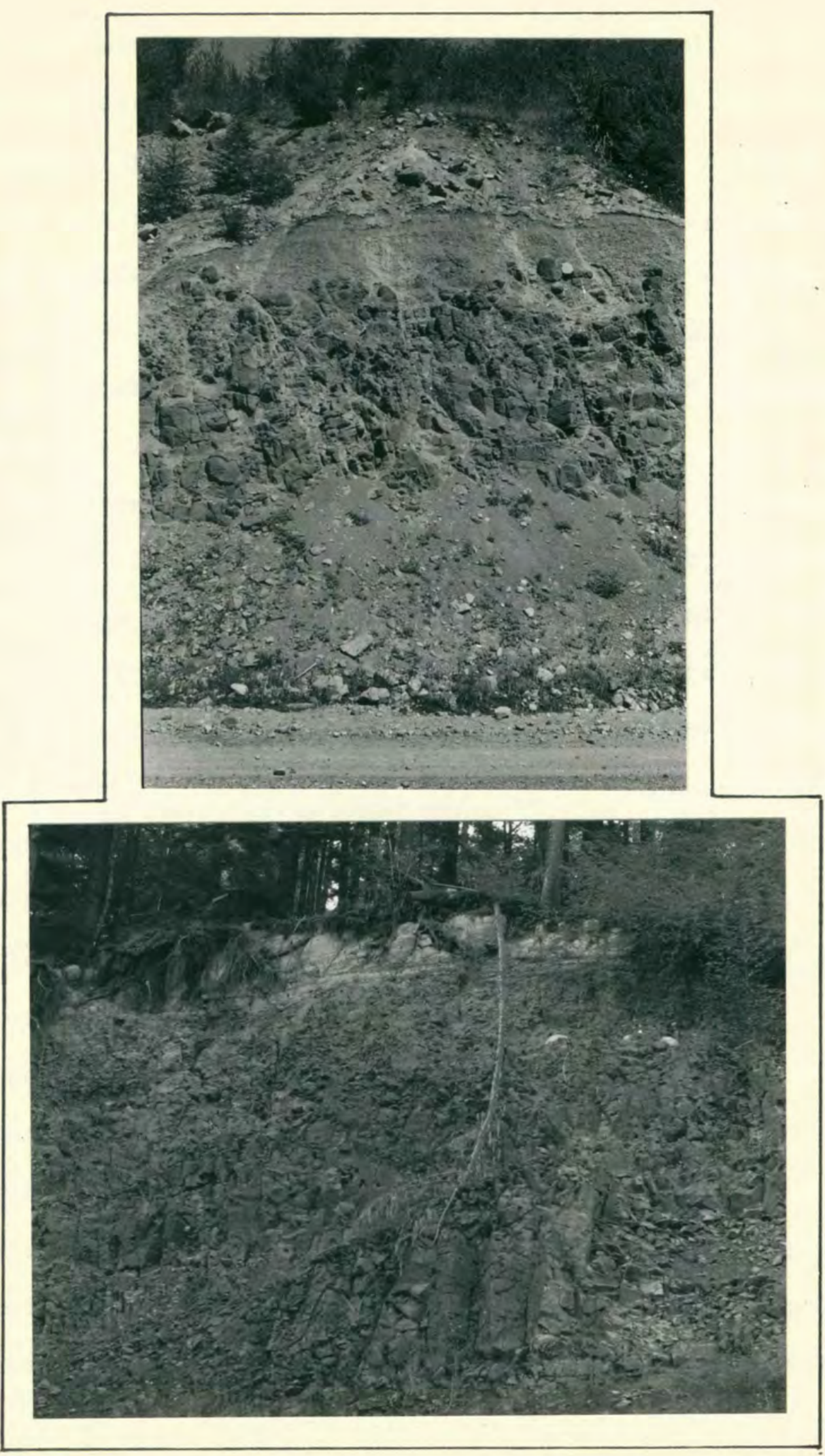

FIGURE 7. VANTAGE INTERBED OVERLYING HIGH MgO GRANDE RONDE BASALT 
hackly and blocky jointed basalt that from a distance take on the appearance of a tiered colonnade. Locally, the hackly and blocky zones may assume the appearance of a crude colonnade and entablature structure such as that expected in a low Mgo Grande Ronde flow. Therefore, in the absence of other information, jointing character alone cannot be considered a reliable criterion for field recognition of high Mgo Grande Ronde flows.

The Prineville flows, on the other hand, are distinguishable from the rest of the Grande Ronde section in the clackamas River area from the standpoint of jointing character. They rarely have hackly entablatures and consist almost entirely of fair to well-developed blocky colonnades that in some place take on a wavy appearance. These flows contrast dramatically with the entablature-dominant, low Mgo Grande Ronde flows above and below them. Once again, it is not likely that the absence of an entablature is due to relative flow thickness, in that individual Prineville flows are predominantly in excess of 35 meters thick and commonly 50 meters thick (Figure 8).

The Prineville flows often have local flow unit contacts or mid-flow vesicular layers, but generally they have relatively thin vesicular zones below their uppermost contacts. The vesicular zone at the top of the uppermost Prineville is usually less than four meters thick, whereas a low Mgo Grande Ronde flow of comparable thickness commonly has a vesicular zone in excess of ten meters thick. Flow 


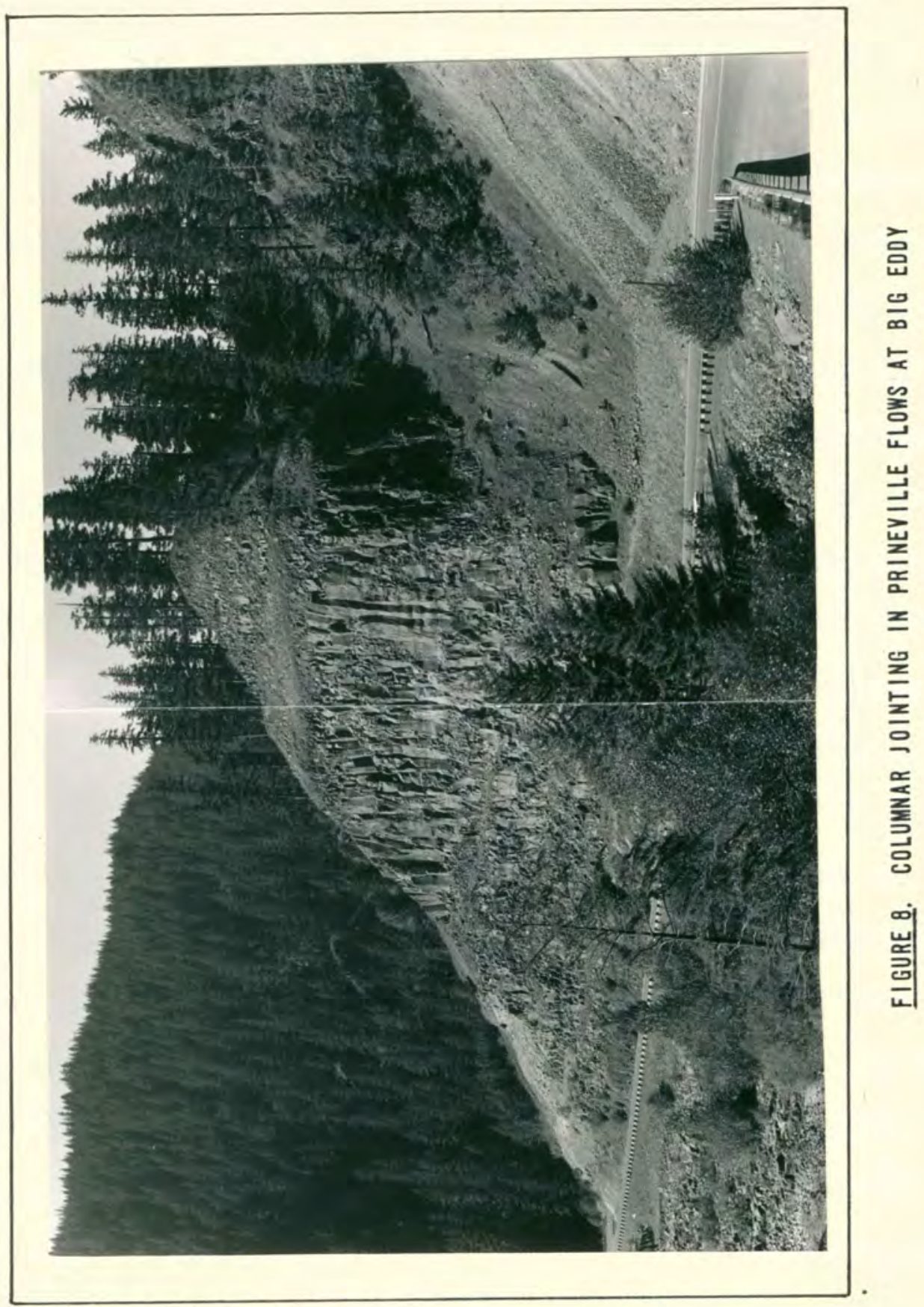


top breccias are also common atop the upper Prineville.

\section{Vantage Member and Other Interbedded Units}

Thick interbedded sedimentary units are common in the Clackamas River area indicating relative nearness to an eroding volcanic highland. This relationship was accurately recognized by Peck, et al. (1964), but the exact nature of the basalt onlap with this highland was not fully understood at that time. Interbeds increase in thickness, in a general sense, from north to south across the area. Hence, they are best developed in the area south of Three Lynx along a roughly east-west trend. Excellent exposures can be seen in both the Fish Creek and the main Clackamas River drainages where either road cuts or near vertical outcrop has made them visible (Figure 9). These units have surprisingly large lateral extent and appear to occur at the same stratigraphic horizons in many of the peripheral areas.

The section at Three Lynx for example (Figure 36, pg.117) corresponds exactly with the section at Cripple Creek (Figure 44, pg.126) in all respects including the position of interbeds. These two sections in fact typify the stratigraphy of the entire map area south and east of Three Lynx. Interbeds, in this instance, become useful local markers within the Grande Ronde Basalt since they are best developed in that formation. There are five horizons that consistently have interbeds in the above sections and are hereafter referred to by number. 


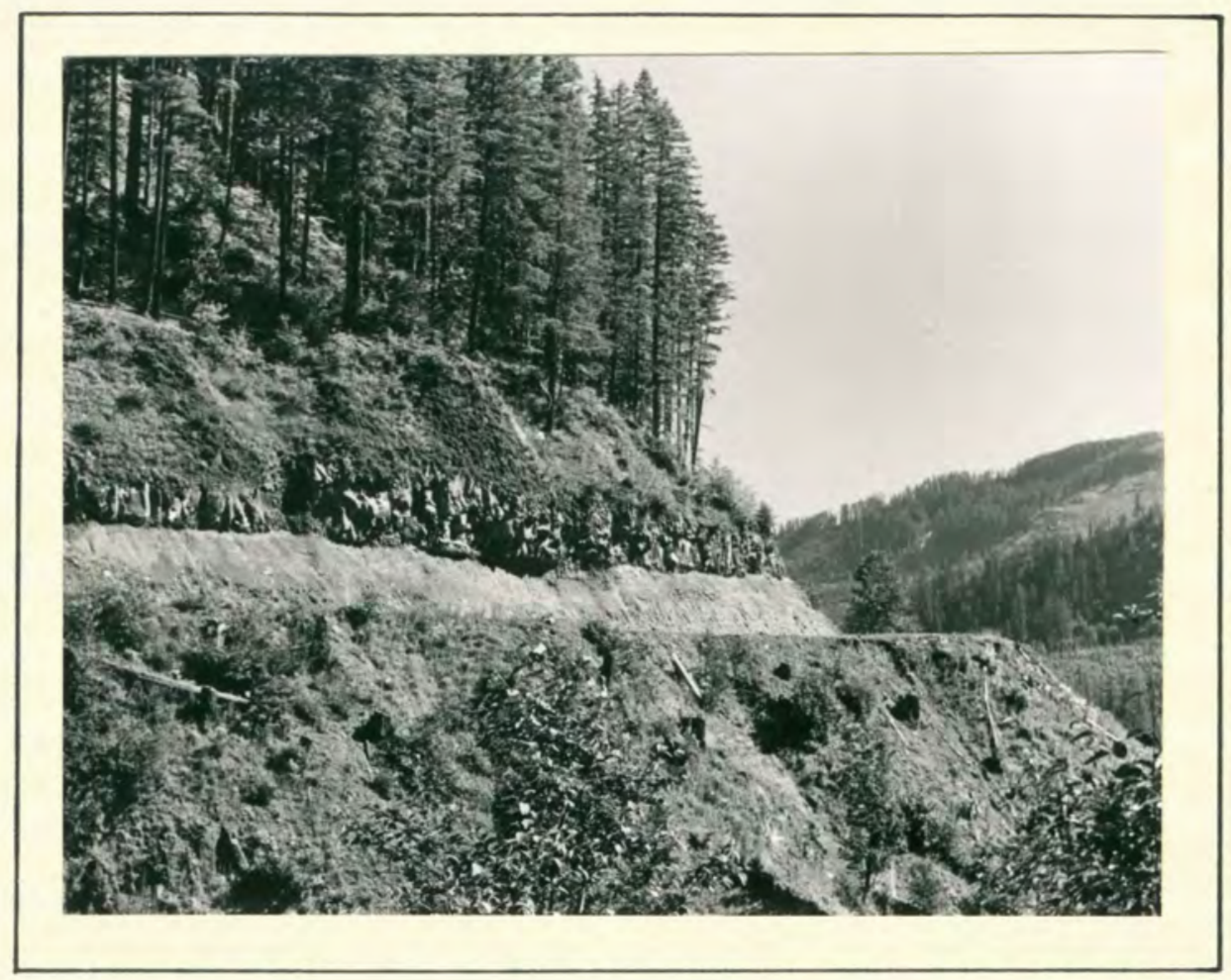

FIGURE 9. INTERBED WITHIN THE LOW MgO GRANDE RONDE BASALT 
"Interbed one" is the thickest of the intercalated units. It separates the lowest exposed normally polarized low Mgo Grande Ronde flows from the reversed flows above and thus marks the $\mathrm{N}_{1} / \mathrm{R}_{2}$ paleomagnetic break. This unit is predominantly laharic in composition with some localized dark-colored stratified sedimentary deposits. These deposits are best exposed between Three Lynx and the Narrows and are greater than 40 meters thick. Interbed one is compositionally equivalent to the Little Butte Volcanic Series exposed nearby.

"Interbed two" occurs at the top of the reversed low Mgo Grande Ronde flows and separates them from the overlying Prineville flows. It is typically dark-colored, wellstratified mudstone, siltstone and lesser sandstone accumulation that is approximately 13 to 17 meters thick in the Three Lynx area. Abundant wood fragments and some leaf fossils were noted in this interbed in the Three Lynx section.

"Interbed three" occurs between the Prineville and the overlying Grande Ronde sequence and is thus a marker for the paleomagnetic break $\left(\mathrm{N}_{2} / \mathrm{R}_{2}\right)$. It appears in both the Three Lynx and Cripple creek sections but is anticipated to be more sporadic in occurrence since this is the thinnest of the pre-Vantage interbeds at three to five meters. The lithologic composition of this unit is locally similar to interbed one, but commonly includes black ashy layers with distilled wood fragments. 
"Interbed four" occurs in the middle of the normally polarized low Mgo Grande Ronde sequence and constitutes a major compositional change within the interbedded sequence. It is consistently the thickest sedimentary accumulation in the area southeast of Three Lynx, commonly exceeding 35 meters, and falls at the base of the thickest flow in the Columbia River Basalt sequence. Good exposures of this sedimentary unit can be seen at the Three Lynx and Cripple Creek sections, in the repeat sequence north of Ripple Brook and near the Lake Harriet Fault (Appendix A \& B). It consists predominantly of light-colored water deposited andesitic volcaniclastics with some tuffs and lahars present locally. In overall aspect, this unit is indistinguishable from the overlying Sardine Formation. An andesitic sill was observed to have intruded this unit at the Three Lynx section, where the interbed evidently provided the path of least resistance. Extensive pillow palagonite in excess of 25 meters at the base of the flow above substantiates a subaqueous environment of deposition.

"Interbed five" presents a problem from the standpoint of stratigraphic nomenclature in that it is a lithostratigraphic equivalent of the Vantage Member of the Ellensburg Formation, clearly separating the Frenchman Springs Member flows from the underlying Grande Ronde flows (Figures 4 \& 5). This interbed is compositionally similar to interbed four, consisting of light-colored andesitic volcaniclastic detrital deposits with some sandstone locally 
(Figure 7). It would not have been considered part of the original Vantage Sandstone (Mackin, 1961; Bingham \& Grolier, 1966) but can be included in the broader Vantage Member of the Ellensburg Formation (Bentley, 1977; Swanson, et al., in press). This latter definition includes a wide variety of sediments such as volcaniclastic detrital deposits along the eastern margin of the Mio-Pliocene Cascade Range that are laterally intertonguing with the sandstone facies originally observed by Mackin.

In the clackamas area, interbed five is clearly a detrital volcaniclastic facies of the Sardine Formation and can be traced laterally into that unit (as discussed later in this chapter). The situation is basically analogous to the Vantage Member merging laterally with the Ellensburg Formation, suggesting that this interbed should be considered a member of the Sardine Formation. However, this unit would still have synchronous boundaries relative to the Vantage Member despite the distances involved. Thus, the name "Vantage Member" is adopted here for the interbed separating the Wanapum and Grande Ronde Basalt, pending a decision regarding the application of the rule of priority (A.C.S.N., 1961).

The Vantage Member has the poorest outcrops of any of the intercalated sedimentary units in the clackamas River drainage since it is usually associated with gentle vegetated slopes. It is not therefore feasible to attempt to trace this light-colored marker horizon directly using aerial 
photographs or by ground observation as can be done in the more arid Columbia Plateau. Fortunately, the Vantage is well-defined topographically in the Clackamas River area. The most striking manifestation of the Vantage Member is the Vantage bench, an exhumed landscape and interformational surface. Despite average thicknesses that are far less than interbeds "one", "two" and "four" near Three Lynx, the topographic expression of the Vantage is by far the most pronounced of any of the interbedded units. This unit, like the other major interbeds, thickens from north to south across the area ranging from approximately three meters near Memaloose Creek (Figure 7) to more than 40 meters along the periphery as seen along the upper reaches of Fish creek (Figure 40,pg.122). Unlike the other major interbeds, the Vantage overlies weathered basalt that represents the longest single interflow time period evident in the Clackamas River area.

The high Mgo Grande Ronde flow top immediately below the Vantage is often weathered to a depth of five to ten meters and has a capping clayey saprolite consisting of decomposed basalt. This layer in concert with abundant water is a slip face over which the overlying units, including the Frenchman Springs member, have long been subjected to downslope movement. Of equal importance to the formation of the Vantage bench is the jointing character of the Frenchman Springs flows which tend to be colonnaded and break up into 
large prismatic blocks. Elsewhere in the Columbia Plateau, the Frenchman springs Member commonly forms rounded hills recessed back on the Vantage bench (Bentley, 1977). The greater amount of rainfall in the western cascades has apparently amplified the effects of landsliding of the Vantage Member. This factor, coupled with the jointing contrast between the Grande Ronde and Wanapum formations, has produced a remarkably prominent bench that can be observed throughout the Clackamas River area. This feature, together with the lithologically distinct Frenchman springs flows above it, is sufficient evidence for confidently mapping the position of the Vantage Member in most localities. In summary, interbedded units in the area of this study increase in number and thickness from north to south as a function of nearness to the pre-basalt highland. The nature of this transition will be discussed later in this chapter. Interbeds can be used effectively as stratigraphic markers on a local scale due to their relatively wide lateral extent, but must be used in conjunction with other observations. These often well-stratified units require the presence of fairly extensive bodies of water along the basalt periphery during the interflow periods and the presence of a degradational source such as nearby highlands. Contemporaneous volcanic activity from a nearby source is indicated by the presence of laharic and tuffaceous units such as those seen in "interbed three" at Three Lynx. The intercalated units record the transition from Little Butte to 
Sardine time and suggest that the sources of one or both of these formations were active during the episodic columbia River Basalt incursions.

Detailed study of the interflow units has high potential significance. Chemical analysis should be conducted on volcanic fragments from volcanic sedimentary units in a stratigraphic sequence extending from the Little Butte Volcanic Series through the Columbia River Basalt interbeds into the Sardine formation. This may provide data useful in evaluating the genetic relationships between these formations and the history of early Cascadian volcanism.

\section{Frenchman Springs Member of the Wanapum Basalt}

Frenchman Springs flows in the clackamas River area closely resemble their counterparts in the Columbia Plateau both from the standpoint of geochemistry and physical characteristics. Table VI shows that a close correspondence exists between the element concentrations obtained using INAA in the clackamas River area and those obtained for the Gingko, Sand Hollow and Sentinal Gap type localities (A.R.H.C.O., 1976, V.I) in south-central Washington. These flows have normal paleomagnetic polarity as determined by a portable fluxgate magnetometer and often have large plagioclase glomerocrysts in a matrix that is generally coarser than underlying Grande Ronde flows. They commonly are blocky, colonnaded and sometimes platy, with individual columns up to three meters in diameter. 
TABLE VI

COMPARISON OF CLACKAMAS RIVER Fe, Na AND TRACE ELEMENT CONCENTRATIONS WITH THOSE OF THE TYPE LOCALITIES

FOR THE FRENCHMAN

SPRINGS MEMBER

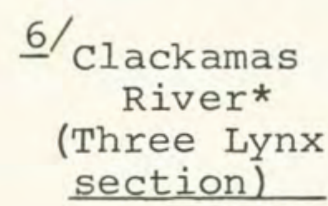

$\mathrm{Na}$

La

Sm

Fe

$\mathrm{Ce}$

Eu

Lu

Th

Hf

Co

Sc

$\mathrm{Ba}$
2.03

25.6

7.4

10.8

53.0

2.2

.64

5. 5

5.4

42.8

37.2

770

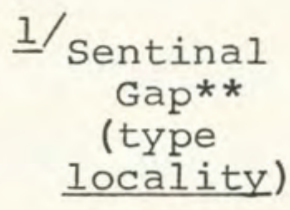

1. 93

28.2

7.9

11.0

N.D.

2.2

N.D.

4.0

5.0

38.6

34.8

735

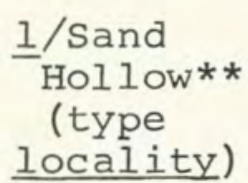

1. 99

26. 7

6.4

11. 1

N.D.

2. 2

N.D.

4.5

4.6

39.2

36.0

700

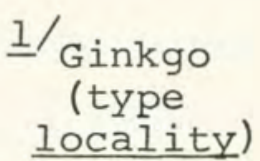

1.93

28.6

6.6

11.1

N.D.

2. 2

N.D.

3.7

4.5

37.4

34.4

730

n/ number of flows or flow units averaged

* average of six samples from TLYX Section Appendix C ** data from A.R.H.C.O., (1976) 
Frenchman Springs flows are poorly exposed in the most of the Clackamas River area. Local landsliding over the Vantage interbed and the prismatic, blocky jointing of the overlying Wanapum flows has resulted in the retreat of these flows to form a rounded hill line behind the prominent Vantage bench. Talus has accumulated on this bench from younger andesitic and basaltic flows above the columbia River Basalt, effectively covering the Frenchman Springs flows in most areas. Exposure is further minimized along the north side of the clackamas River by an intra-canyon volcanic sequence that has replaced the Frenchman Springs along a trend parallel to the present Clackamas River. This ancestral Clackamas River channel was cut to a depth near or below Vantage in many localities and therefore resulted in the complete or partial removal of the Frenchman Springs along portions of the north side of the present valley. Frenchman Springs flows are not distinctive on a flowby-flow basis from the standpoint of geochemistry at the present state of the art, nor are they individually distinctive from the standpoint of paleomagnetics based upon field determinations. Future laboratory studies will be needed to determine whether or not the single reversed Frenchman Springs flow observed in the oregon City area and elsewhere is present in the Clackamas River area (Kienle, 1971; Sheriff, unpublished data).

Eight stratigraphic sections containing three or more flows were examined, including Promontory Park, Memaloose 
Creek Road, Big Eddy, Fish Creek airstrip, Three Lynx, Whale Head, Lake Harriet and S562A (Appendixes A and B). Several field-recognizable characteristics make it possible to correlate between these sections, the most important of which are distinctive jointing characteristics and the abundance and nature of plagioclase phenocrysts (Table V). The following discussion will employ the terms "phyric", "abundantly phyric", "rarely phyric" and "aphyric" to express the numbers of plagioclase phenocrysts that are fieldobservable in a square meter of outcrop surface (Figure 5). These terms are widely used among Columbia River Basalt researchers on a somewhat unofficial basis and are not welldefined. For the purposes of this study, these terms are defined as follows:

$$
\begin{array}{ll}
\text { abundantly phyric } & \text { more than } 10 \text { phenocrysts } \\
& \text { per square meter } \\
\text { phyric } & - \text { one to } 10 \text { phenocrysts } \\
& \text { per square meter } \\
\text { rarely phyric } & \text { less than one phenocryst } \\
& \text { per square meter } \\
\text { aphyric } & \text { no phenocrysts observable } \\
& \text { anywhere in the flow }
\end{array}
$$

"Phenocrysts" in this instance refer to crystals that are greater than five millimeters long.

The basal flow in the Frenchman Springs section in the area of this study is often partially or entirely covered. Most exposures owe their existence to the thickness of this unit which ranges between 30 and 35 meters, thus allowing the top to protrude through the mantle of cover in many 
instances. It is a phyric flow having a very distinctive jointing character in the form of the most well-developed prismatic colonnade in either the Wanapum or the Grande Ronde sections. Individual columns are from one to two meters in diameter and sometimes extend continuously from contact to contact as at Three Lynx and Big Eddy (Figure 36, pg. 117 \& Figure 43, pg.125). At these two localities, the basal Frenchman springs flow forms an impressive cliff above the Vantage bench, with prismatic boulders weighing several thousand kilograms each accumulated at its base like a post pile (Figure 10). Other flows in the section lack both the thickness and the geometric perfection of jointing that this flow possesses.

The second flow above the Vantage Member is an anethyma in the sense that it is the only Frenchman springs flow to be consistently dominated by a hackly entablature. This is also a regional peculiarity since, as previously mentioned in Chapter II, Wanapum flows in general are characterized as having blocky or colonnaded jointing. This flow has a blocky colonnade that constitutes only $20 \%$ of the total flow thickness. The entablature is not unlike that of a low Mgo Grande Ronde flow. The second flow is sporadically phyric with large areas that appear to be aphyric and some areas that are abundantly phyric. It differs from other flows by virtue of having extremely large plagioclase phenocrysts that locally are up to four centimeters long. 


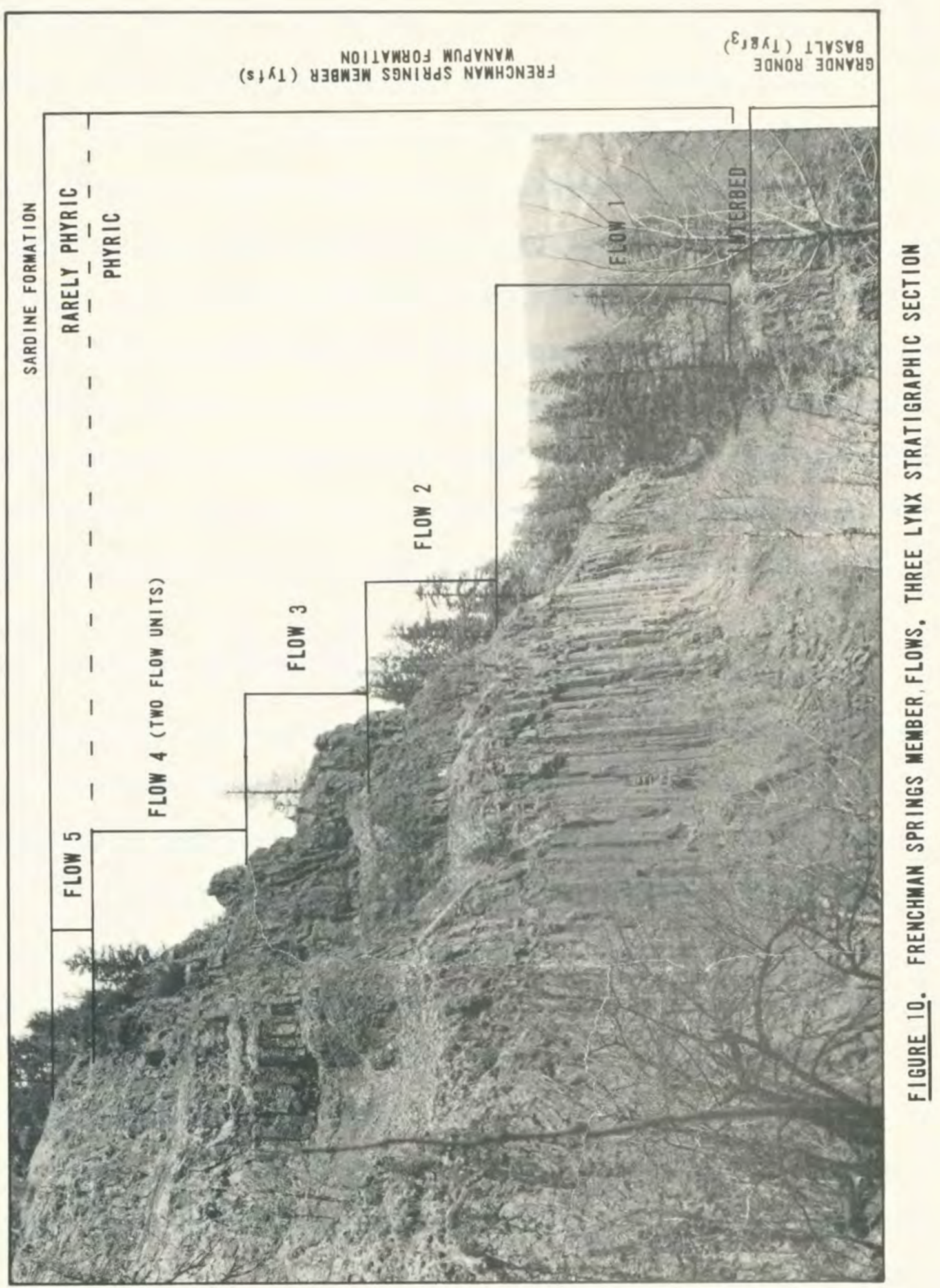


The third flow type is actually a group of one to three flows or flow units having similar characteristics. They tend to be entirely colonnaded or blocky in jointing with individual columns up to four meters in diameter. This flow type is phyric and has a relatively open, coarse-grained and light-colored matrix compared to the dense dark colored matrix in the second flow. It is similar in many ways to flow " +2 " in the Portland area described by Beeson, et al. (1976a). There is usually only one of these flows present, but this varies across the area. There are, for example, three flows or flow units of this type at Three Lynx (Figure 36, pg.117) and one at Memaloose Creek road (Figure 49, pg. 131).

A fourth flow type consists of one to two flows that are rarely phyric, having the typical blocky colonnaded jointing of Wanapum basalts elsewhere. These flows are metallic gray and have a medium-grained texture. They tend to to shatter easily when struck by a hammer where fresh outcrop occurs such as in recent road cuts. This flow type has been largely excluded from the onlap margin to the south. The fifth and final flow type is represented by a single abundantly phyric flow at the Promontory Park stratigraphic section (Figure 4l, pg.123). It is blocky but more irregularly jointed than flows lower in the section. The groundmass of this flow is relatively finer grained than other Frenchman Springs flow with the exception of the second above Vantage. This flow was excluded from all other parts 
of the study area as will be discussed in the following section.

From the standpoint of proposed plateau terminology (Bentley, 1977), flows one and two resemble the Ginkgo type, having uniformly abundant and locally large phenocrysts. However, the uppermost flow in the Frenchman Springs section discussed above also resembles the Ginkgo type. The third flow type could be either Ginkgo or kelly Hollow type (phyric) and the fourth rarely phyric type most closely approximates the Union Gap or Sand Hollow (aphyric). Hence, the use of these names is not clearly applicable to the Clackamas River Frenchman Springs basalts.

Correlation within the Clackamas River Area

The factors discussed in this chapter were used collectively to correlate the Columbia River Basalt within the Clackamas River area and thereby produce a geologic map. These included trace element geochemistry, major oxide geochemistry, paleomagnetics, petrography, stratigraphic position, interbeds, lithology, jointing and other physical characteristics. Although some are more useful than others, none of these factors should be treated as an exclusive means of identifying all units within the sequence. The Frenchman Springs Member, for example, has variable trace element geochemistry that sometimes overlaps that of low Mgo Grande Ronde units. However, it can be clearly identified on the basis of distinctive lithology, jointing and stratigraphic 
position. Conversely, the Grande Ronde subunits can be identified with confidence on the basis of geochemistry and paleomagnetics but not by lithology. Therefore, all variables were considered in the process of correlation. Map symbols from Figure 5 will hereafter be indicated in parenthesis to clarify the unit names discussed.

Grande Ronde Basalt. The stratigraphic sections at Big Cliff, Fish Creek Forest Camp, Fish Creek airstrip, Roaring River and Three Lynx (Appendix A) were selected for geochemical analysis because of their completeness, geographic location and the absence of structural complications. The Frenchman Springs Member (Tyfs) was excluded from analysis in all but the Three Lynx sections, since this unit was readily field-identifiable. The geochemical subunits of the Grande Ronde Basalt discussed previously occur in each of these sections as listed in Appendixes C and D.

The distribution of the Grande Ronde Basalt in the five geochemical sections is shown diagrammatically in Figure 1l. Each of these sections is shown in its approximate geographic position relative to the other sections, projected to a northwest/southeast oriented line, although this relationship is not to scale. The Roaring River section, for example, is actually eight kilometers north of either the Fish Creek Forest Camp or the Three Lynx sections as shown in Appendix A. Heavy black lines represent boundaries between the major geochemical subunits, while thin black lines are probable individual flow correlations. Dashed 


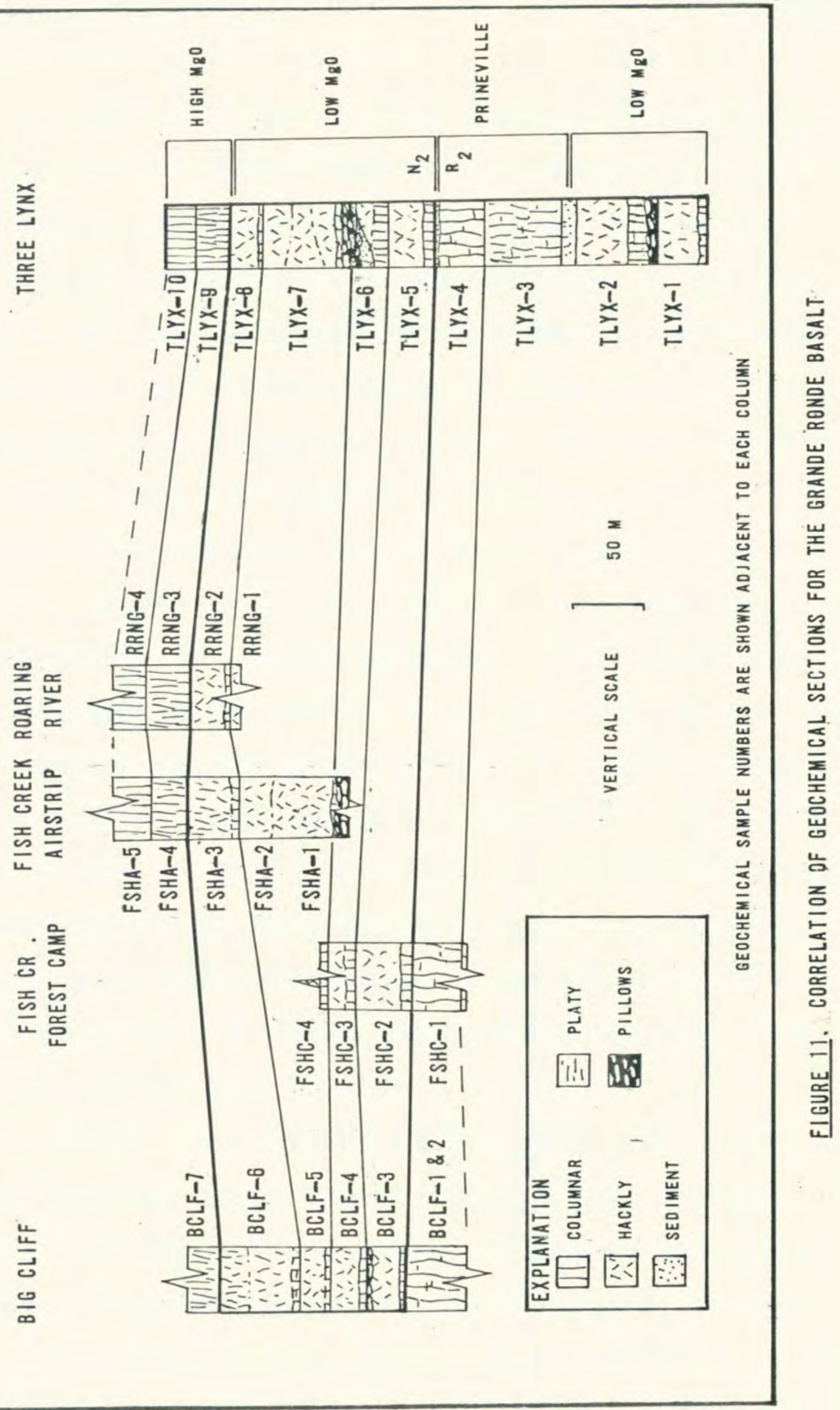


lines represent presumed correlations where the relationship is obscured by cover.

Distribution of Grande Ronde subunits is remarkably uniform across the area. Figure 11 illustrates how the high and low Mgo Grande Ronde (Tygr $_{3}$ and Tygr $_{2}$ ) and the upper Prineville flow (Typv) all span the 15-kilometer distance between Three Lynx and Big cliff with very little change in thickness or in the number of flows. There are two flows in the high MgO (Tygr $_{3}$ ) sequence at Fish creek airstrip, Roaring River, Three Lynx, and probably at Big Cliff as well. Despite cover above the first two of these sections, the thicknesses are assumed to be very similar to the other two since the break occurs at the Vantage bench. Thus, thicknesses shown in Figure 11 are only slightly less than actual. The post-Prineville low Mgo Grande Ronde flows (Tygr 2 ) total four in number at Three Lynx and at Big Cliff. They have nearly the same combined thickness at each locality although individual flows vary considerably. Only the uppermost Prineville flow (Typv) is visible across the entire area, but it also can be seen to have a consistent thickness in each of the sections where it occurs.

The Grande Ronde Basalt thins rapidly to the south of the main Clackamas River where it becomes progressively interdigitated with the volcanoclastic pile of the Little Butte Volcanic Series/Sardine Formation (Figure 12, map pocket). Interbeds thicken rapidly as successive flows lens out. This relationship is best illustrated by the exposures 
along the east side of the Fish Creek Divide above Sandstone road (Figure 13). The Big Creek section, described in Appendix B (Figure 47, pg. 129) is shown at the far left on Figure 13. It consists of two flows separated by approximately 100 meters of interbedded volcanoclastic deposits. The lower of these flows appears to be a typical entablature dominant low MgO Grande Ronde flow $\left(\mathrm{Tygr}_{2}\right.$ ), and the upper appears to be a high Mgo Grande Ronde flow (Tygr 3 ) pending geochemical confirmation. The 100-meter deposit between the two is compositionally similar to "interbed four" at Three Lynx shown at the far right in Figure 13. The increase in thickness of this interbed from Three Lynx to Big Creek essentially replaces two low Mgo Grande Ronde flows (Tygr 2 ). Hence, this part of the Grande Ronde section appears to be lensing out as a flow group associated with an ever-thickening tongue of volcanoclastic material. The diagrammatic representation in Figure 13 shows a similar hypothetical relationship involving other interbeds lower in the section. Frenchman Springs Member. Like the Grande Ronde Basalt, the Frenchman Springs Member (Tyfs) intertongues with the Sardine Formation (Figure 13). This relationship is clearly shown between the Whale Head (Figure 48, pg. 130) and Three Lynx sections, where the Vantage Member thickens from two to 22 meters at the expense of the Frenchman Springs. A similar relationship can be seen along the west ridge of the Fish Creek valley (Figure 12), where the Vantage thickens from two meters to 40 meters over a distance of about two 


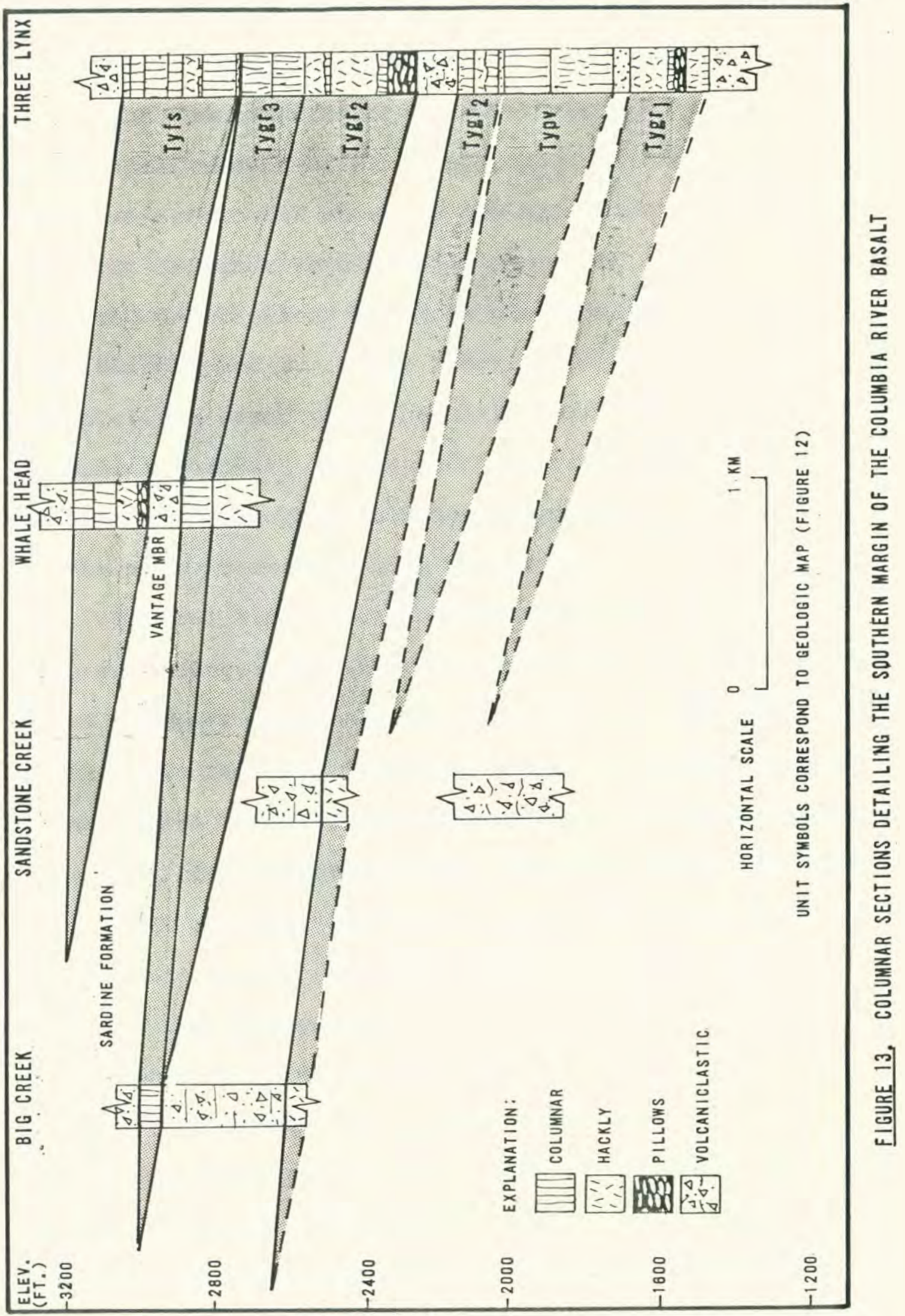


The lithologies of this 40-meter sedimentary sequence are described in Appendix B (Figure 40, pg. 122).

The Frenchman Springs Member was studied in numerous localities, eleven of which are shown in Figure 14. Each measured section is shown in its approximate geographic position relative to all other sections. Locality data and detailed descriptions for most of these sections appear in Appendixes A and B. Heavy black lines represent positive correlations based upon the characteristics discussed in the preceding chapter, and dashed lines represent probable correlations. Correlated horizons include the unit boundaries of the flow groupings shown on Figure 5 .

Several significant observations can be made from Figure 14 concerning the distribution of the Frenchman Springs flows in the clackamas River area. First, the stratigraphic sections in the main clackamas River canyon are located along a line oriented approximately northwest to southeast. These include Promontory Park, Memaloose Road, Big Eddy, Fish Creek airstrip and Three Lynx. The Columbia River Basalt lenses out along a generalized east-west line south of Three Lynx and the disappearance of the Frenchman Springs occurs well before that of the underlying Grande Ronde (Figure 12). A similar statement can be made concerning the rarely phyric and phyric Frenchman Springs. The rarely phyric Frenchman Springs disappears well before the phyric and generally increases in both number of flows and thickness from south to north. Also, the highest flow in the overall section is 


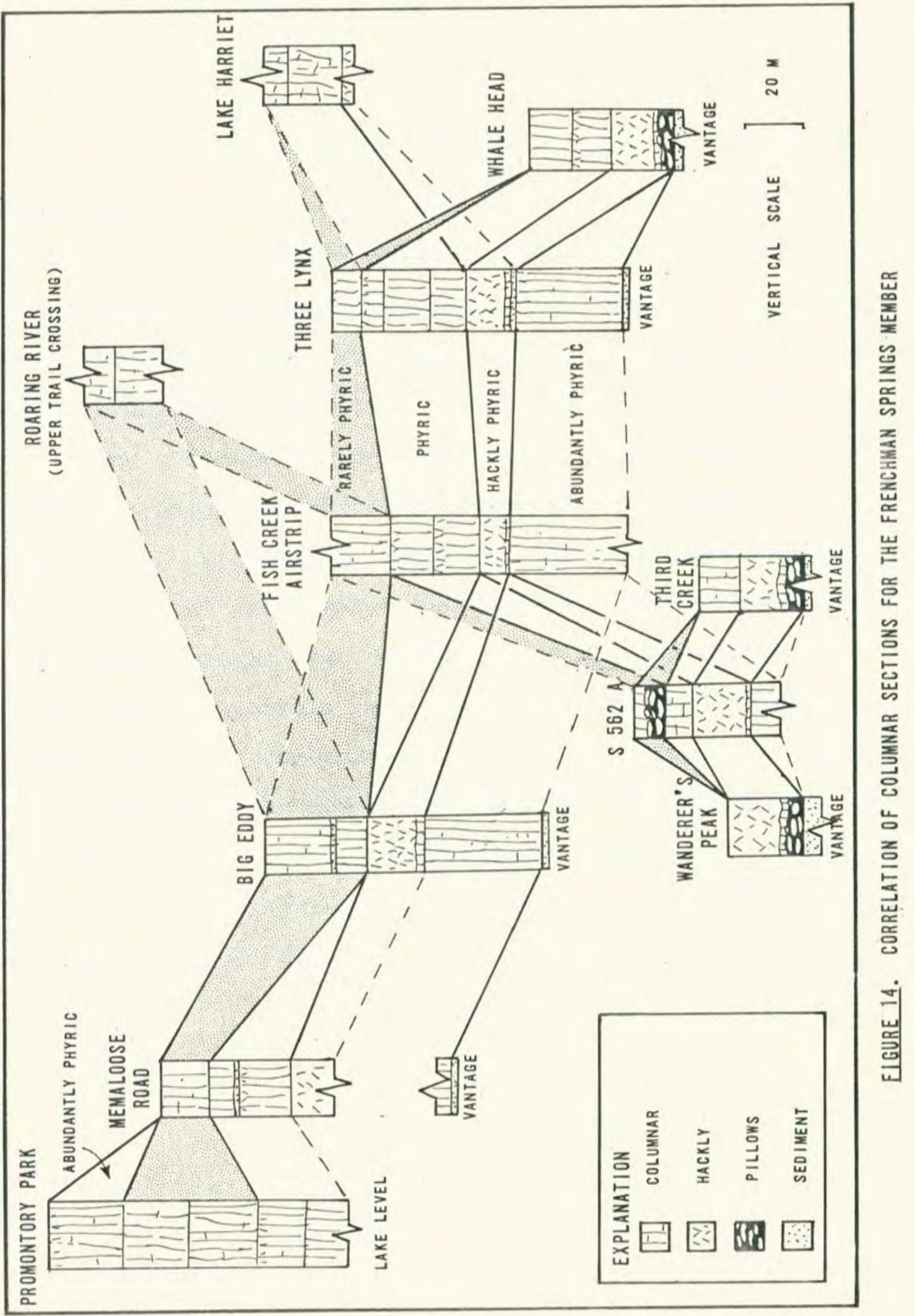


unique to the Promontory Park section, the northernmost exposure of the Frenchman Springs Member.

A second important observation concerns the overall thickness of the Frenchman Springs sequence. Like the Grande Ronde units, the Wanapum Basalt has remarkably uniform overall thickness where complete or nearly complete sections are exposed in the main Clackamas River canyon. Promontory Park, Memaloose Road, Big Eddy, Fish Creek airstrip and Three Lynx are all 90 to 100 meters thick. This compares to 70 meters observed in the oregon City area (Beeson, et al., 1975). However, the Frenchman Springs at Promontory Park could be as thick as 140 meters if flows one and two are present at the unexposed base of the section (Figure 14). Flows one and two above Vantage are present in all major sections north of the Columbia River Basalt margin except for the Promontory Park section. Flow one, however, disappears rapidly toward the south and is succeeded by flow two as the basal flow in the section. This relationship can be seen in the Wanderers Peak, Third Creek and Whale Head sections (Figure 14). 
CHAPTER IV

STRUCTURE

In the past, the structure of the Columbia River Basalt within the Clackamas River drainage has been largely unknown. Previous mapping that has covered all or part of the area includes Barnes and Butler (1930), Callaghan and Buddington (1938), Wells and Peck (1961) and Peck, et al. (1964). In all, one broad fold and two "minor" faults were identified on these maps. All are shown on the map by Peck, et al. (1964) and occur on the perimeter of the columbia River Basalt exposures. The fold, called the "Clackamas anticline", was mapped along a northeast trend in the vicinity of Ripplebrook, while the faults were mapped in the southern Fish Creek valley and near Lake Harriet. Peck also recognized the northwest dip of the basalts as being pervasive.

The lack of mapped structure in the Clackamas River area is partially explained by the fact that previous mapping was reconnaissance in nature. However, this explanation avoids the underlying reason, that the stratigraphy of the seemingly monotonous Columbia River basalts had not been fully developed at the time of these mapping efforts.

Application of the stratigraphic tools discussed in detail in Chapter III has resulted in a clear understanding 
of the Columbia River Basalt stratigraphy, a prerequisite for structural mapping. Thus far, eleven major and several lesser faults have been identified, and the nature and orientation of folding has been clarified.

Faults are the most striking structural phenomenon in the area of this study, and northwest trending faults dominate nate, as is shown on Figure 15. These faults cut the shallowly dipping Columbia River Basalt sequence in an en echelon pattern that is distributed across the entire map area. Northeast and north-south trending faults also occur, but are less numerous. The collective nature of these faults is varied since some are strike-slip and others are dip-slip, and uniform in the sense that fault planes are predominantly vertical or near-vertical. There is an absence of steeply dipping flows in the vicinity of faults within the clackamas River canyon and near faults to the southeast. This suggests that there is minimal drag associated with these structures. However, faults northeast of the main canyon, such as those along Roaring River, are frequently associated with steep dips which may indicate folding or drag. Folding over the rest of the area is of a very broad nature and generally does not affect the overall northwest dip of the columbia River Basalt.

Folds

Peck, et al. (1964) identified and mapped a broad anticlinal fold called the "Clackamas Anticline", with axial 


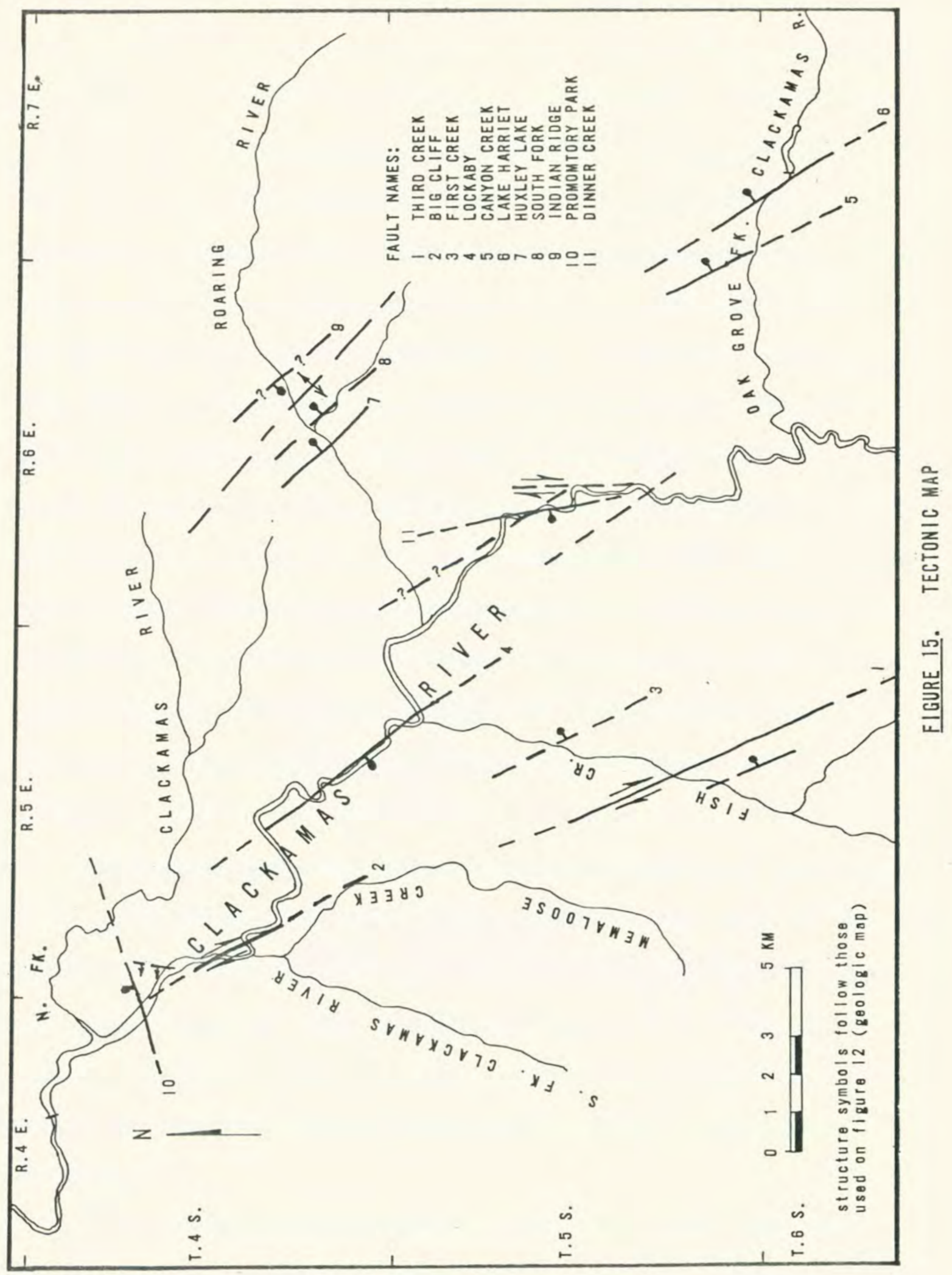


trace trending to the northeast and passing through the eastern edge of this study area near the Ripplebrook Ranger Station. Attitudes obtained in the Columbia River Basalt (Figure 12) could support the presence of such a structure, but only if it is asymmetrical toward the southeast and plunging to the north. The basalt near Lake Harriet on the east side of the anticline dips to the northeast, while flows on the west dip consistently to the northwest. Flows near the axis are flat-lying as would be expected. However, faulting involving at least two major breaks occurs to the east of the flat-lying basalts raising the possibility that rotation or drag has caused the northeast dips observed in that area. These faults are northwest trending and thus cross the axis of the "Clackamas Anticline" at an angle of approximately $60^{\circ}$. The geometry of this fold is not clearly defined to the south of the Oak Grove Fork of the Clackamas River.

Folding over the majority of the remaining area is of a very broad nature, with dips normally less than $6^{\circ}$ to the northwest. The shallow dips in the clackamas River canyon are only slightly greater than the gradient of the river itself, so that rapid changes in the stratigraphy along the river are nearly always symptomatic of faulting rather than folding.

Both the disappearance of the top of the Columbia River Basalt at North Fork Reservoir and the appearance of the base of the section near Three Lynx are in part the 
result of dip-siip movements on normal faults rather than dip alone. The net effect of this faulting and particularly that at North Fork Reservoir is to shatter the illusion that one is traversing the entire Columbia River Basalt sequence when driving from northwest to southeast through the clackamas River canyon. Less than half of the seventeen flows are exposed at highway level across the area due to the presence of these and other faults. Thus, an excursion through the Clackamas River canyon is an experience limited to the lower half of the section. The prominent road level flow near the Fish Creek bridge is the same flow exposed at highway level at the base of Big Cliff; both are Prineville (see Appendix A). Flows exposed at Big Eddy and upstream from the Fish Creek bridge roadcut are deeper in the section due to being on the upthrown side of the northwest trending Lockaby fault discussed later in this chapter. Hence, changes in dip and folding have a limited effect on the overall configuration of the Columbia River Basalt in the Clackamas River canyon. The South Fork of Roaring River is the only area other than Lake Harriet where steep dips occur in the basalts. In one way, the two areas are analogous in that both have steep dips in the vicinity of major faulting. However, the dips in the Roaring River area strongly suggest an anticlinal structure rather than rotation associated with faulting or drag.

Broad folding (or faulting) during columbia River Basalt time is indicated by the distribution of the Wanapum 
Basalt. The rarely phyric Frenchman springs flows are totally excluded from the southern margin of the basalt and generally thicken toward the north. Also, the only known exposure of the uppermost phyric flow occurs at Promontory Park, the northernmost stratigraphic section (Figure 14). The best explanation for this is subsidence or faulting within the pre-rarely phyric basalt flows to the north of the onlap margin.

\section{Northwest Trending Faults}

Third creek fault. A right lateral strike-slip fault trending $\mathrm{N} 30^{\circ} \mathrm{W}$ is exposed in roadcuts on either side of the Fish Creek valley (Figure 15). It extends to the southeast at least as far as the crest of Fish Creek Divide and probably beyond. It is nearly on trend with the Big Cliff fault to the northwest (discussed next) and the two may be linked.

Sheared basalt is exposed on the west ridge (S.W. $\frac{1}{4}$, S.W. $\frac{1}{4}$ section 23 T.5 S., R. 5 E.) where the fault crosses under road $S$ 562. A pillow palagonite complex in the low MgO Grande Ronde $\left(\right.$ Tygr $_{2}$ ) is cut by numerous slickensided en echelon fractures. Similar fractures occur peripheral to the fault on the north side of Third Creek to the southeast, cutting both basalt flows and interbedded sediments (N.E. $\frac{1}{4}$, N.E. $\frac{1}{4}$ section 35 T.5 S., R.5 E.). Slickensides and step structures at both localities show a right-lateral sense of motion (Figure 16). 


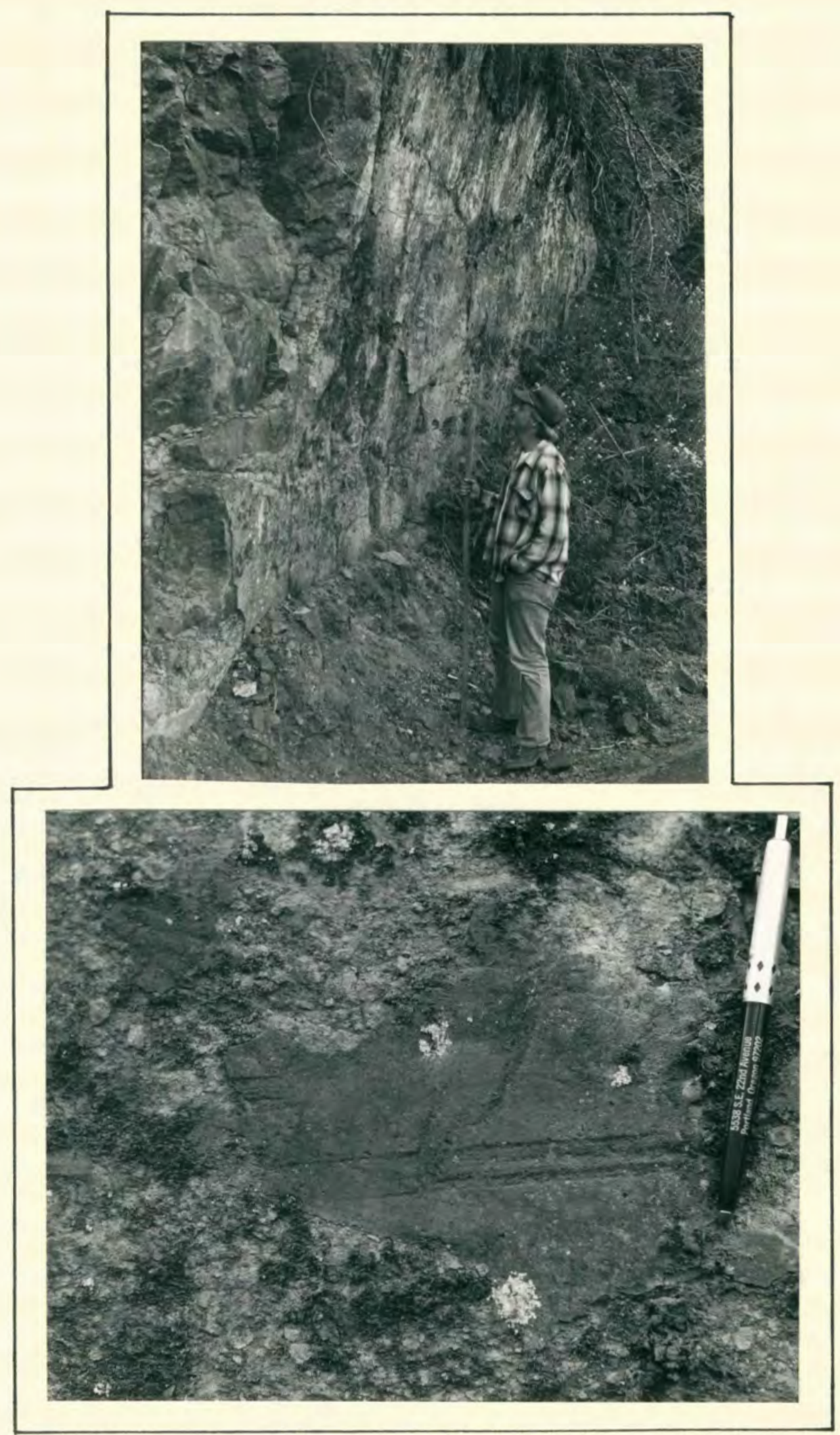

FIGURE 16. HORIZONTAL SLICKENSIDES AT THE THIRD CREEK FAULT 
The northeast side of the fault is down relative to the southwest as shown on cross-section A (Figure 17, map pocket). This could be a result of either normal faulting preceding latest strike-slip motion or an apparent normal offset produced by strike-slip movement alone. The latter alternative is consistent with right-lateral movement, considering the $4^{\circ}$ northwest dip of the basalts (e.g., .5 kilometers of strike-slip movement would produce a 35-meter apparent normal offset).

The Vantage geomorphic bench is offset down to the northeast along the west side of the Fish Creek valley. This prominent feature can also be seen to narrow from about .5 kilometer to less than .I kilometer across the fault (Figure 12). The down to the northeast configuration is also supported by the lens out of the rarely phyric Frenchman Springs Member at the approximate position of the Third Creek fault (Figure 14). Further stratigraphic evidence involves truncation of interbeds within the Grande Ronde Basalt. Two interbeds, the lower shown in Figure 9, are clearly offset down to the northeast across the Third Creek fault.

The absolute strike-slip offset on the Third Creek fault cannot be determined based upon present data. However, estimated apparent vertical offset in the youngest units is less than 35 meters, based upon the position of the Vantage bench of either side of the fault and upon observed displacement of interbeds. 
Big Cliff fault. A strike-slip fault is exposed at Big Cliff near the confluence of the clackamas River and Memaloose Creek. A horizontally slickensided gouge zone can be seen trending $\mathrm{N} 30^{\circ} \mathrm{W}$ in one of the most prominent ravines. Like the Third creek fault, there are numerous flanking en echelon fractures, many of which are manifested as northwest-trending ravines. Unlike the Third creek fault, there is no evidence of a normal component of displacement on the primary break or on any of the other adjacent fractures. This circumstance is readily evident in a visual inspection of Big Cliff, where five individual flow contacts extend undisplaced across numerous fractures including the Big Cliff fault (Figure 24, pg.105).

The Big Cliff (strike-slip) fault is associated with a prominent air photo linear both southeast and northwest of Big Cliff. The projection of this fault to the southeast crosses a well-developed saddle in the south canyon wall of the Clackamas River, and shear sets are exposed in road cuts along the Memaloose Creek Road, S 45. To the northwest, the fault bends slightly toward the west and crosses the clackamas River, projecting toward North Fork Reservoir and Promontory Park. The magnitude of movement along this fault cannot be objectively determined at this time in the absence of transverse trending units. Also, little exposure occurs on trend with this feature in the younger overlying units, further complicating such a determination. A right lateral sense is presumed on the map for this fault (Figure 12) on 
the basis of it being on trend with the Third Creek fault. First creek fault. The broad bench at Fish Creek airstrip is bounded on the north and on the south by northwest trending normal faults that essentially drop it down in a graben-like structure. The southern or "First Creek fault" is evidenced by a noticeable displacement in the Vantage bench of 70 to 100 meters down to the north. This stratigraphic drop occurs along an axis that is sub-parallel to the First Creek drainage. A narrow gouge zone trending N $30^{\circ} \mathrm{W}$ can be seen cutting Grande Ronde flows along road S 504, a few hundred yards from its junction with calico Road (s 505). Dips generally steepen by $3^{\circ}$ to $5^{\circ}$ across this fault. The northwest and southeast projections of this structure are poorly exposed, hampering a more detailed assessment of the magnitude and sense of movement. However, the Vantage bench drops distinctly to the northeast across an axis that appears to be coincident with the $\mathrm{N} 30^{\circ} \mathrm{W}$ trend of the First Creek drainage.

Lockaby fault. The northern graben perimeter is defined by another normal fault with a throw of approximately 105 meters down to the southwest. It closely parallels the Clackamas River, trending $\mathrm{N} 30^{\circ} \mathrm{W}$ and is well-exposed where it crosses the river at Lockaby campground, one kilometer due north of the confluence of the Clackamas River and Fish Creek (Figure 12). This fault extends at least $5.5 \mathrm{kilo-}$ meters to the northwest of Lockaby campground, and is exposed in a road cut at Big Eddy. It also extends into the ridge 
flank north of Fish Creek airstrip southeast of Lockaby where the Vantage bench is offset more than 100 meters. The fault crosses the river approximately 200 meters north of the highway bridge spanning the Clackamas River at the south end of Lockaby campground. The overall character of this fault is like the Third creek fault in that it is paralleled by adjacent en echelon shear sets (Figure 18). The principal gouge zone is covered, but its position is made obvious at river level by the juxtaposition of contras trasting units. The upper prineville flow (Typv) can be seen on the downthrown southwest side and is the same flow seen at highway level at Fish Creek Forest Camp (Figure 26, pg.107). The uppermost reversed Grande Ronde flow (Tygr 1 ) occurs on the upthrown northeast side of the fault. An interbed (interbed two) overlying this flow is truncated by the fault.

The thickness of the various geochemical types within the Grande Ronde have been shown to be remarkably consistent across the area. Hence, the displacement evidenced by the juxtaposition of the upper Prineville against the top of the uppermost reversed low Mgo Grande Ronde flow is 105 meters, based upon the thicknesses of equivalent flows observed at Three Lynx. The remarkable similarity in the stratigraphic sequence between Three Lynx and Big Cliff strongly supports the accuracy of this conclusion (Figure 11). The thickness of the Columbia River Basalt sequence from the base of the upper Prineville flow to the Vantage Member is 240 meters at 


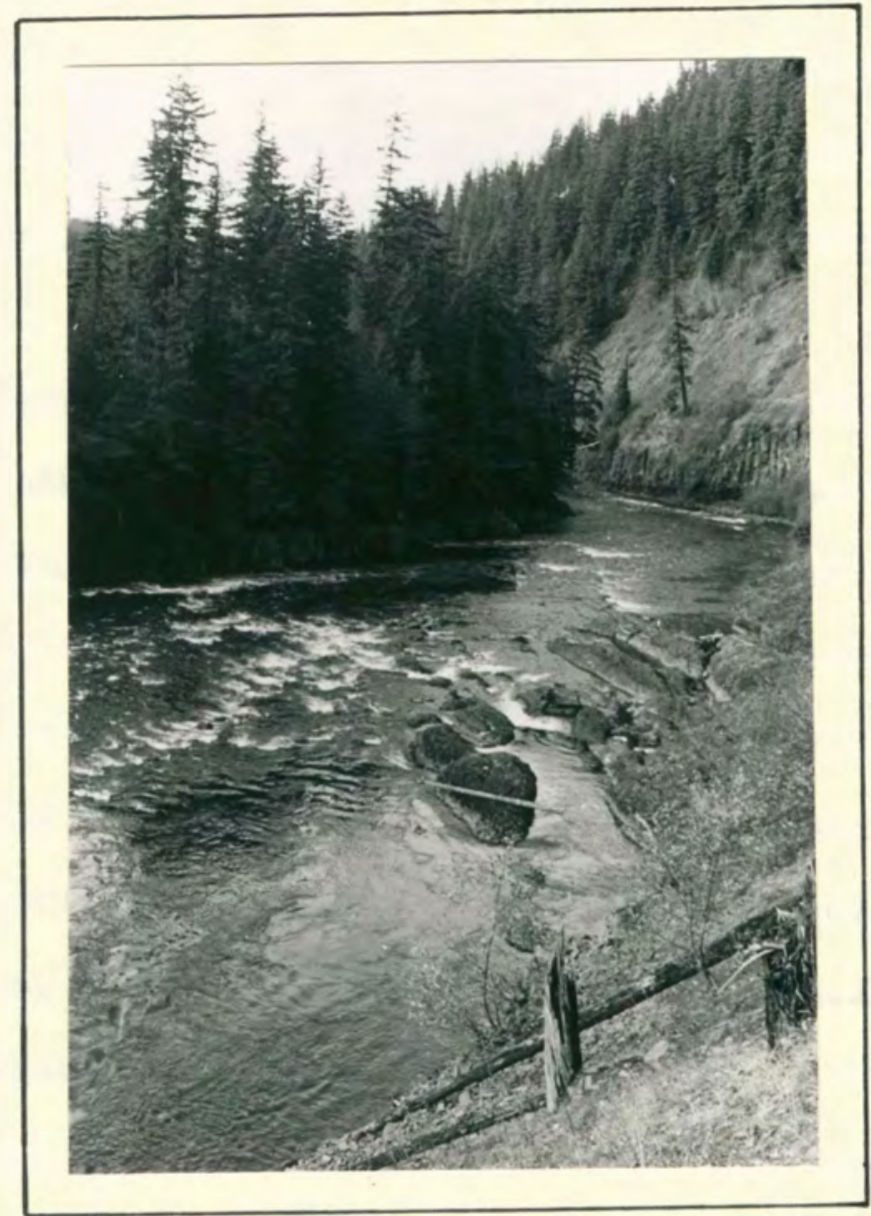

FIGURE 18. LOCKABY FAULT EXPOSURE 
Three Lynx, 220 meters at Big Cliff, and 225 meters at Big Eddy (Appendixes A \& B). The same sequence measured across the fault is 350 meters at the Fish Creek Forest Camp section, indicating a stratigraphic repeat across the fault of approximately 110 to 130 meters, agreeing closely with the offset determined above.

Canyon Creek fault. The present of a fault west of Canyon Creek (Figure 15) is indicated by stratigraphic repetition within the Columbia River Basalt observable along road $S 404$

The first exposures of Columbia River Basalt from east to west along 5404 occur in the center of section 31, in and around a gravel quarry approximately . 5 kilometer west of Canyon Creek. The section consists of an interbed in excess of eight meters thick (interbed four), overlain by two normally polarized flows. These flows are the uppermost low Mgo Grande Ronde flows ( Tygr $_{2}$ ) observed elsewhere in measured sections, with the overlying high Mgo Grande Ronde and Frenchman Springs flows removed by erosion as indicated by the presence of the canyon creek intracanyon sequence. This intracanyon flow series consists of five basalt flows with reversed magnetic polarity, having a combined thickness of 135 meters, separated from the underlying Grande Ronde flows by a substantial accumulation of fluvial gravels (Figure 46, pg.128).

The same two Columbia River Basalt flows and underlying interbed can be seen at a quarry near Half-pint Creek 
along S 404, approximately $2.5 \mathrm{kilometers} \mathrm{to} \mathrm{the} \mathrm{west}$ (N.E. $\frac{1}{4}$, N.W. $\frac{1}{4}$, section 36, T. 5 S., R. 6 E.), Figure 46, pg. defining a stratigraphic offset of approximately 130 meters down to the east over the $2.5 \mathrm{kilometers} \mathrm{covered} \mathrm{interval.}$ Lake Harriet fault. A second fault crosses the oak Grove Fork of the Clackamas River, approximately two kilometers east of the Canyon Creek fault. Unlike the Canyon Creek fault, this one is exposed and can be observed in a road cut located along S 57, two kilometers west of Lake Harriet (S。W. $\frac{1}{4}$, N.E. $\frac{1}{4}$, section 5, T. 6 S., R.7 E.). A substantial fault gouge can be seen flanked by two columbia River Basalt units; the fault has the outward appearance of a normal fault with steep dips occurring in the surrounding rocks. It is a $\mathrm{N} 30 \mathrm{~W}$ trending structure with an essentially vertical fault plane. The throw on the fault of 150 to 200 meters down to the east is indicated by the juxtaposition of the basal pillow complex of the fourth Grande Ronde flow below Vantage $\left(\right.$ Tygr $_{2}$ ) against phyric Frenchman springs (flow one, two or three). This relationship is shown by Figure 19. Thicknesses of displaced units are once again based upon those of the Three Lynx Frenchman Springs and Grande Ronde sections (Appendix A), which are considered to be representative of the thicknesses and sequence in the vicinity of the Lake Harriet fault. Identification of the specific Frenchman Springs flow east of the fault was not possible due to the effects of intense hydrothermal alteration. Rocks adjacent to the fault have been altered and 


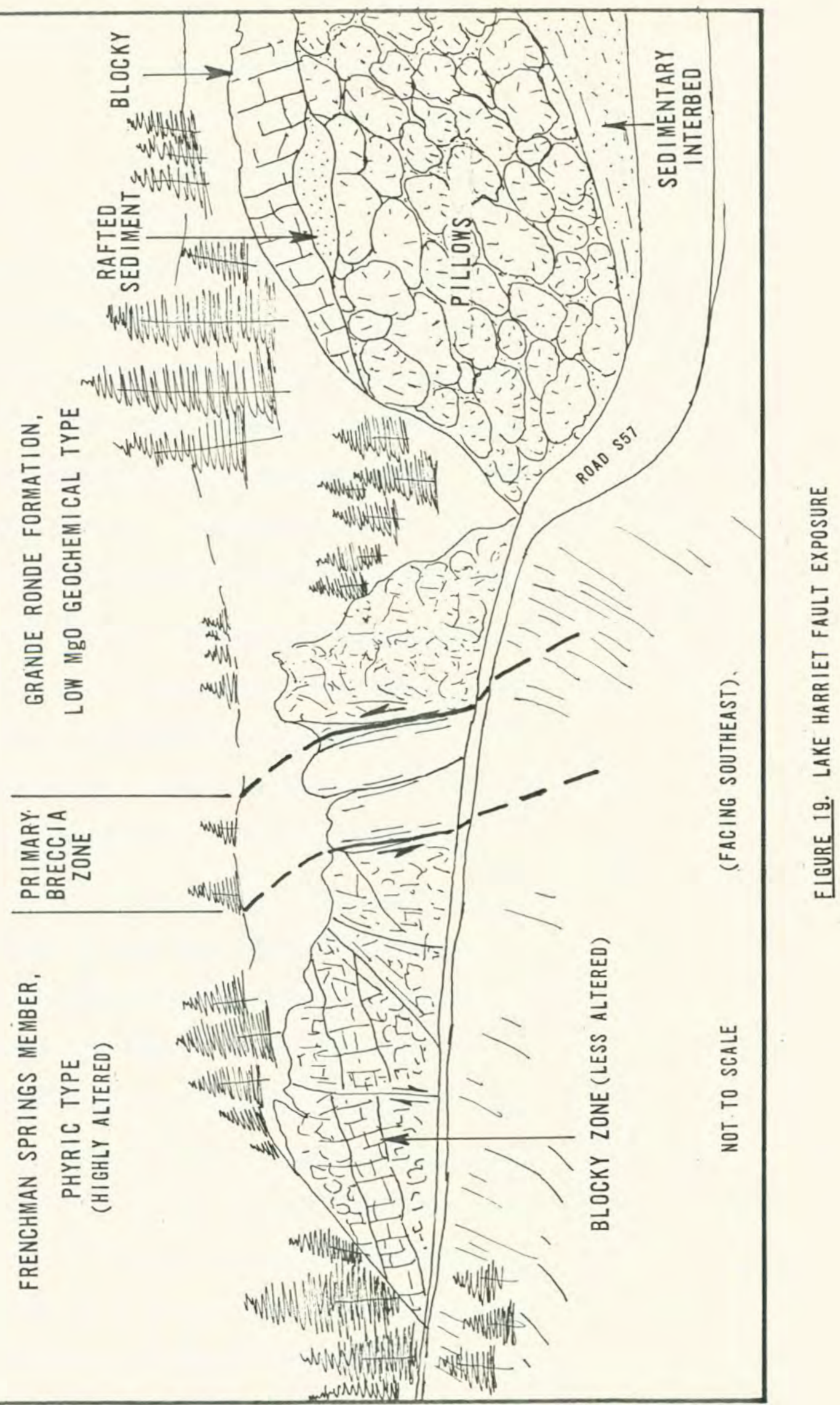


mineralized. However, the presence of recognizable phenocrysts in the limited unaltered exposures east of the break argues strongly for locating the flow within the first three flows above Vantage.

Mineralization along the Lake Harriet fault is more intense than anywhere else in the map area. Cinnabar has been mined commercially in the area between the abovementioned locality and Lake Harriet Dam. Alteration within the Frenchman Springs Member is so intense that it has been rendered locally unrecognizable. Opalization of contacts is extensive and amygdaloidal vesicular zones are common.

The overall aspect of faulting along the Oak Grove Fork is one of stairstep that are incrementally down to the northeast as shown in cross-section B (Figure 17, map pocket). The structural relief across a five-kilometer wide zone extending from Silver Tip Work Center to Lake Harriet is greater than 400 meters. All but 50 meters of this can be attributed to the two faults described above. The remainder can be explained by dip which varies between $10^{\circ}$ and $18^{\circ}$ toward the northeast near Lake Harriet. The presence of the intracanyon basalt sequence between the two faults strongly suggests a fault-controlled drainage pattern in postColumbia River Basalt time. In the absence of more definitive data, the west Canyon creek fault is assumed to be en echelon with the eastern Lake Harriet fault, based upon the prevalence of minor fractures in this orientation and upon stratigraphic considerations that limit the fault to 
the northwestern quadrant.

Huxley Lake fault. The structures in the Roaring River drainage upstream from the Huxley Lake trail crossing are the most complex and least accessible in the entire map area. Continuity exists in the Columbia River Basalt stratigraphy between the confluence of Roaring River with the Clackamas River and Huxley Lake trail crossing (S.W. $\frac{1}{4}$, section 34). The thick entablature of a prominent low Mgo Grande Ronde flow can be traced visually over the entire distance without noticeable offset. However, upstream from the trail crossing, the Vantage Member drops abruptly to river level, or approximately 200 meters down to the northeast.

The Roaring River geochemical section (Appendix A) is topped by Vantage and dips at $20^{\circ}$ toward the southwest. The top of the uppermost high Mgo flow (Tygr ${ }_{3}$ ) can be traced to within 50 meters of river level near a major waterfall (Figure 32, pg. 113) $0.5 \mathrm{kilometer} \mathrm{above} \mathrm{the} \mathrm{trail} \mathrm{crossing,}$ where the dip has decreased to $6^{\circ}$. Although details are obscured by landsliding downstream from the falls, the presence of abundant Ginkgo type Frenchman springs basalt float in the bed load of the river is a strong indication that the Vantage Member has indeed dipped down to and possibly below river level adjacent to the fault. The orientation of the Huxley lake fault is readily detected on aerial photographs. There is a very prominent photolinear trending approximately $\mathrm{N} 40^{\circ} \mathrm{W}$, along which the 
Vantage bench is truncated by the fault to be replaced by landsliding on both sides of the river canyon. The previously prominent low Mgo Grande Ronde entablature also vanishes from view along this linear, presumably to well below river level. The landsliding evident northeast of the fault is directly attributable to the resulting lithological contrast wherein resistant cliffs of Columbia River Basalt are juxtaposed against relatively incompetent intercalated pyroclastics and lavas of the Sardine Formation or younger volcanics.

South Fork fault. A second major discontinuity and strong photo linear exists along what appears to be a parallel axis to the first, roughly coincident with the channel of the South Fork of Roaring River approximately 1.5 kilometers upstream from the Huxley Lake trail crossing (Figure 12). The Vantage bench is offset down to the northeast from 100 meters above river level to below river level. The Roaring River geochemical section, a prominent cliff, is the last major exposure southwest to the fault and is readily visible on aerial photographs. Upstream from this section and the confluence of the South Fork and Roaring River, exposures of Columbia River Basalt cease abruptly and volcanoclastics occur well below the last observed position of the Vantage Member. Lack of exposure greatly hampers a detailed determination of displacement on this fault, but if the entire Columbia River Basalt section is in fact displaced to the river level or below, the minimum throw would be approximately 200 meters down to the northeast. The absence 
of river level exposures and of basalt cliffs in the upper ridge slope northeast of the fault suggests that this is indeed the case.

Indian Ridge fault (?). The Columbia River Basalt reappears approximately $1.5 \mathrm{kilometers} \mathrm{upstream} \mathrm{from} \mathrm{the}$ South Fork fault (center of section 26, T.4 S., R.6 E.). The basalt dips away to the northeast, directly opposing the dips observed at South Fork (Figure 12). The collective configuration on both localities is that of an anticline with a collapsed center occupied by younger volcanics. The South Fork fault and the absence of basalt outcrops to the northeast of it strongly suggest a graben-like collapse structure that would require one or more faults in the vicinity of Indian River (Figure 12).

\section{Northeast Trending Faults}

Promontory Park fault. The Columbia River Basalt is truncated at North Fork Reservoir by the northeast trending Promontory park fault. It trends approximately $\mathrm{N} 60^{\circ} \mathrm{E}$ and is largely responsible for the disappearance of the Columbia River Basalt beneath younger volcanics.

The most visible evidence of the existence of this fault is the abrupt disappearance of the prominent Vantage bench along the south side of the clackamas River near Promontory Park. This horizon drops approximately 170 meters down to the northwest in less than 400 meters distance to a position that is well below lake level at the cliff near 
Promontory Park (N.E. $\frac{1}{4}$, S.W. $\frac{1}{4}$, section 18, T.4 S., R.5 E.). More than 90 meters of Frenchman Springs flows is exposed in the cliff face above lake level at that locality, all of which is replaced by low Mgo Grande Ronde flows a short distance to the east, along the south shore of the lake (Figure 12).

This relationship is not as clear on the north side of the clackamas River, where landsliding occurs. However, the first road cut seen when entering the clackamas River canyon traveling east from Promontory Park is consistent with the above-mentioned data (N.E. $\frac{1}{4}$, S.W. $\frac{1}{4}$, section 18, T.4 S., R.5 E.). This outcrop is mineralized and generally deformed and might be considered to be a large landslide block under other circumstances. However, the stratigraphy coincides with that seen on the south shore of the reservoir. The Vantage Member is visible in the bulldozed cut above the road, and blocky, phyric Frenchman springs occurs above that (Figure 20). This exposure is up dip from the Promontory Park cliff locality and is thus in the proper stratigraphic context of the downthrown side of the fault. The position of the fault is limited to the covered interval between this outcrop and those that occur approximately 400 meters further east along the highway (N.W. $\frac{1}{4}$, N.W. $\frac{1}{4}$, S.E. $\frac{1}{4}$, section 20 , T.4 S., R.5 E.). Low MgO Grande Ronde flows are exposed at road level and the Vantage is located approximately 140 meters above the road on the upthrown side of the fault. A sharp north-south trending flexure (possibly a fault) occurs 


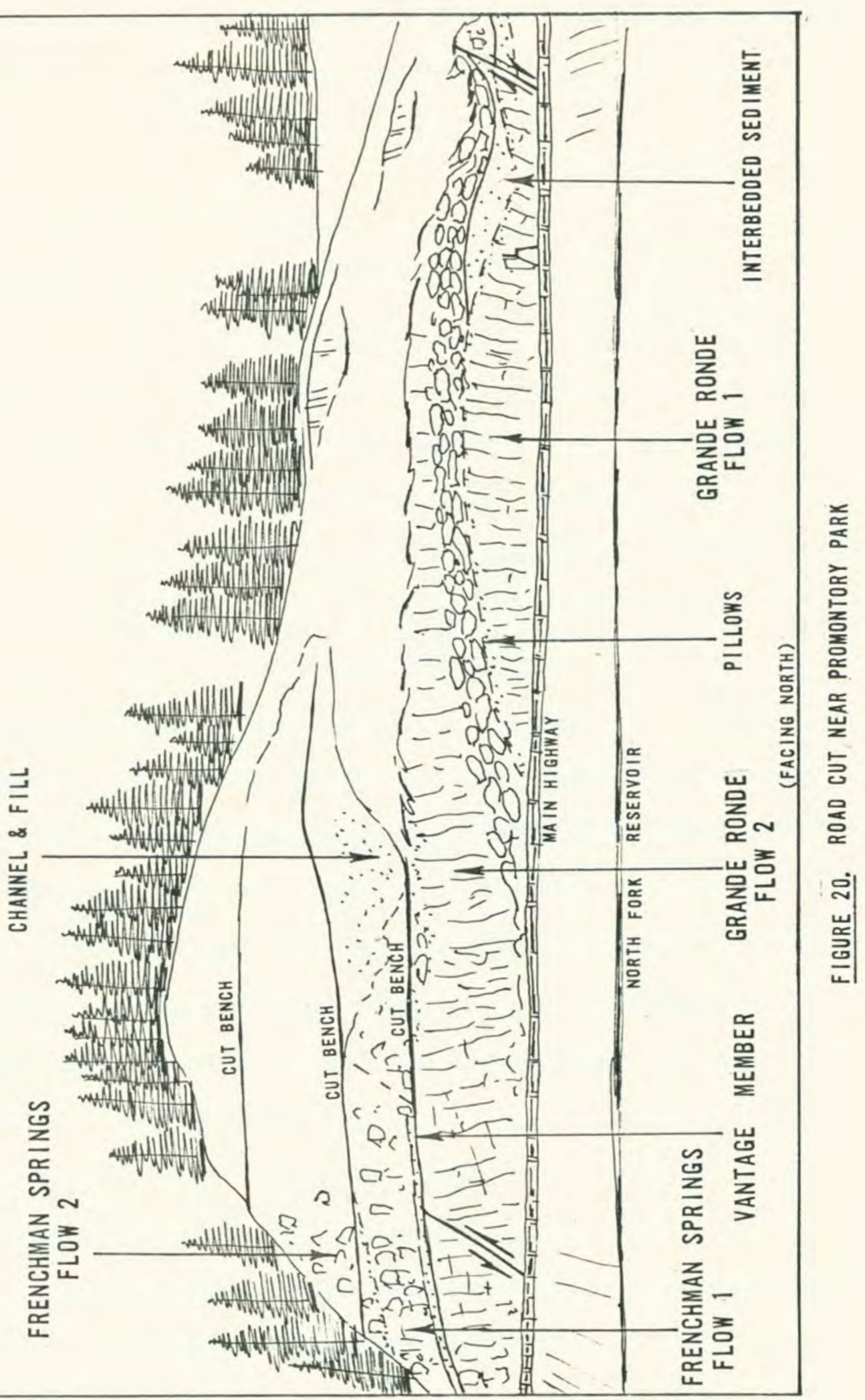


at the eastern end of the extensive road cut approximately one kilometer east of Promontory Park, and also is down to the west.

North-South Trending Faults

Dinner Creek fault. The north-south trending Dinner Creek fault (Figure 15) offsets the base of the columbia River Basalt up to the east near Three Lynx. It is well exposed along the main highway approximately 400 meters east of Dinner Creek (N.W. $\frac{1}{4}$, N.W. $\frac{1}{4}$, S.E. $\frac{1}{4}$, section 16, T.5 S., R. 6 E.). A mudflow breccia can be seen atop a normal low Mgo Grande Ronde flow (Tygr,), both of which are cut by at least three closely-spaced breaks (Figure 21). The collective throw on these fractures is in excess of 20 meters down to the west. The fault planes dip $80^{\circ}$ west and strike $\mathrm{N} 5^{\circ} \mathrm{W}$, with slickensides and breccia present along them. The faults intersect the outcrop at a very shallow angle so that the fault breccia is essentially spread out across the face of the exposure. Both dip-slip and strike-slip slickensides were observed in peripheral fractures. However, the main zone is without question dip-slip, with step structures clearly indicating a sense consistent with visual evidence. Columbia River Basalt flows on trend are visibly offset in what appears to be the same sense and magnitude, due east of the "surge tank" at Three Lynx, along the southern wall of the clackamas River canyon. Thus, this fault can be traced at least as far south as Three Lynx and 


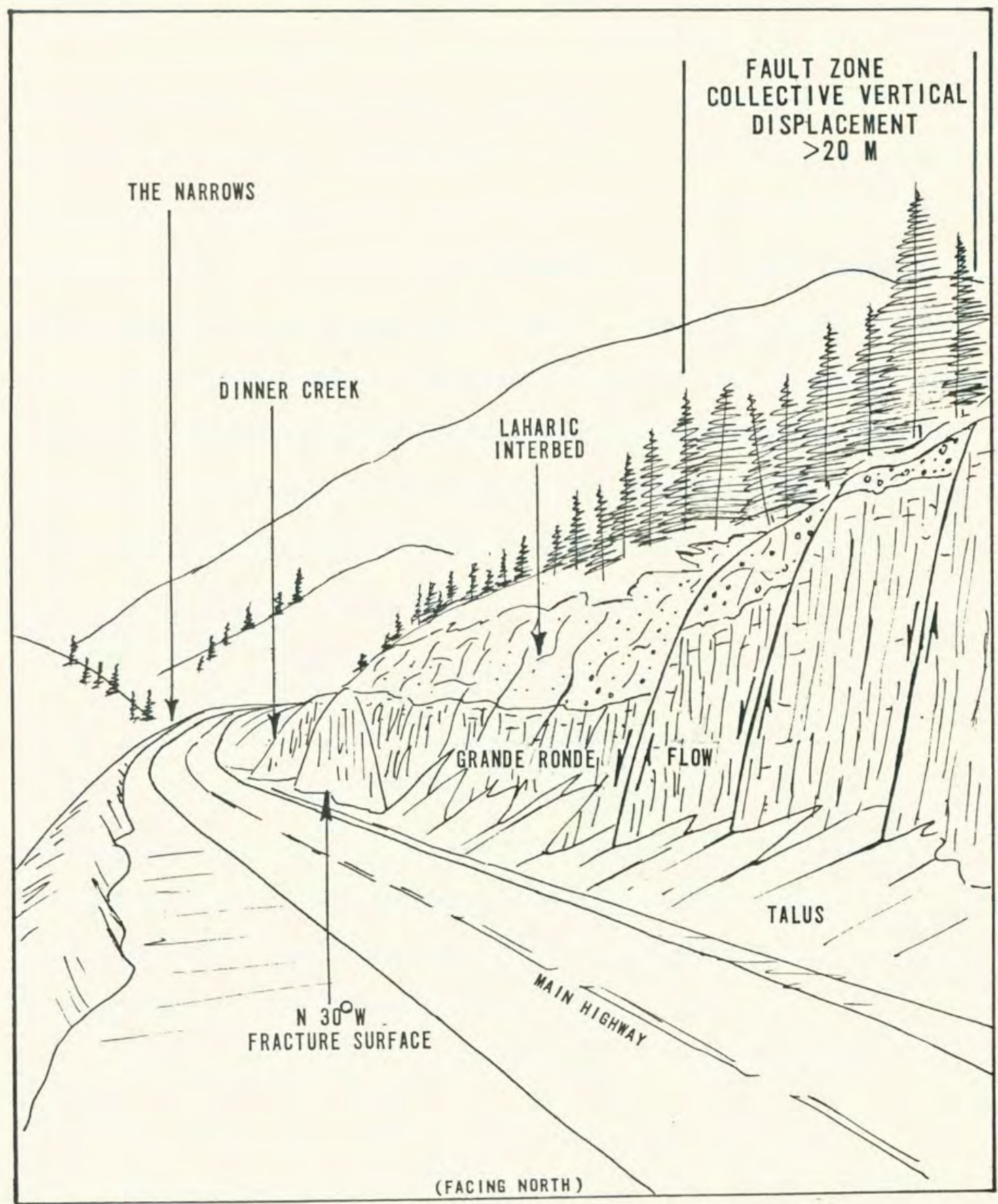

FIGURE 21. DINNER CREEK FAULT EXPOSURE 
probably projects under the landslide west of Dinner Creek as wel1.

other faulting. Evidence of strike-slip shear is exposed at the top of the flume above the powerhouse at Three Lynx (S.E. $\frac{1}{4}$, N.W. $\frac{1}{4}$, S.W. $\frac{1}{4}$, Section 22, T.5 S., R.6 E.). Horizontal slickensides are present on north-south trending surfaces that are probably peripheral to a main fault zone. This appears to be part of a series of north-south faults that extends en echelon between Dinner creek and the vicinity of the powerhouse. Step structures have a distinct right-lateral sense where observed, and no vertical component of movement could be detected.

\section{Tectonic Summary}

The common feature among the faults in the clackamas River study area is the consistently vertical and nearvertical fault planes. This, together with the prominent northwest trending right lateral strike-slip faults at Third Creek and Big Cliff, strongly suggests that both the greatest principal $\left(\sigma_{1}\right)$ and the least principal $\left(\sigma_{3}\right)$ stress axes are within the horizontal plane (Billings, 1972).

The predominant trend of faults range between $25^{\circ}$ and $40^{\circ}$ west of north, and at least one northeast fault is oriented approximately $50^{\circ}$ east of north. This argues strongly for north-south compression and east-west extension in the Clackamas River area. The right lateral shear observed along northwest faults is consistent with this 
model. Similarly, left lateral strike-slip along northeast faults would be anticipated, but none has been observed thus far.

The age of deformation in the clackamas River area can be defined only in the broadest relative terms at this time. This is due partially to the time stratigraphic limitations of the study as defined and to the paucity of age dates on the youngest overlying units which range in age from Pliocene to Recent (Peck, et al., 1964).

Most faulting in the Clackamas River area is at least as young as post-Sardine (late Miocene) and many faults appear to post-date the intracanyon sequence north of the main river canyon (Quaternary). This estimate is based upon the topographic expression of faults forming saddles in the Sardine Formation southwest of the Clackamas River, such as seen along the Third Creek and Big Cliff faults. It is also based upon the fact that the present clackamas River and its tributaries constitute an etched fracture pattern that faithfully reflects the en echelon pattern of the faults in the area (Figure 12). Some tributary channels are cut into the top of post-Sardine intracanyon lavas along trends that can be related to fault trends in the Clackamas River canyon. Others do not appear to break this youngest surface. An accurate analysis of age of deformation will, by necessity, involve mapping the distribution of these youngest units and obtaining absolute ages. 
CHAPTER V

\section{GEOLOGIC HISTORY}

The first flood basalts that entered the vicinity of the present Clackamas River covered a fairly flat preexisting surface where bodies of standing water near vegetated dry land must certainly have existed. This environment is indicated by the dark-colored, stratified mudstones and siltstones containing leaf fossils and wood fragments that are seen in many localities at the base of the Columbia River Basalt sequence. Pillow complexes observed at the base of the lowest flow are testimony to the presence of standing water.

The Columbia River Basalt was an episodic and alien incursion into an area that was marginal to a pre-existing and active volcanic regime. In some localities, lahars and lava flows can be seen both beneath and laterally intertonguing with the sedimentary deposits mentioned above. The flows are predominantly andesitic and the lahars contain accessory clasts that are also predominantly andesitic. Quiet water sediments are rapidly replaced to the south by volcanic deposits beneath the basalt in what must have been the foothills of a highland or mountain range. The columbia River Basalt filled existing stream channels in this more rugged topography like the rising waters of a lake. 
More than 515 meters of flood basalts inundated the area in less than two million years, centered at about 15 million years ago; and yet sufficient time elapsed between episodes for forests to grow and for thick sequences of water-laid volcaniclastic deposits to accumulate. Sedimentary deposits of variable thickness occur between nearly all of the flows in the sequence on a local basis. However, thick and widespread accumulations occur only at certain stratigraphic horizons.

The first Columbia River Basalt flows to enter the area were normally polarized and were of the low Mgo Grande Ronde geochemical type $\left(\right.$ Tygr $\left._{0}\right)$. A single flow of this type is intercalated within the Little Butte Volcanic Series near Three Lynx. Sources of the Little Butte were active both before and after the entry of this flow into the area. This activity is demonstrated by the thick accumulation of volcaniclastics and lavas seen both above and below.

Flows that followed were of the same geochemical type but entered the area during a reversed magnetic polarity epoch $\left(\right.$ Tygr $\left._{1}\right)$. They penetrated a significantly greater distance to the south than did their normally polarized predecessors, overrunning terrain where lakes were present and vegetation was well established. Dark-colored stratified lacustrine deposits containing abundant wood fragments and leaves occur beneath the oldest of these flows. Pillows developed over wide areas beneath this flow as bodies of water were encountered. An environment of deposition similar 
to the pre-existing one quickly re-established itself following the latest of these flows.

The Prineville flows (Typv) interrupted the lacustrine regime, entering the area in rapid succession. Once again, forests were overrun and immolated by the rapidly moving lavas. Pillows up to three meters in diameter were formed where bodies of water were entered. Coaly layers can be seen in many places, as well as the remains of tree trunks at the base of the prineville flows. The rapid succession of these two flows is indicated by the absence of pillows and of significant sediment accumulations between them. A period of time of unknown duration elapsed following the Prineville episode, during which sedimentary and laharic facies were deposited. During this time, a paleomagnetic reversal event took place. Vegetation was once again present as evidenced by the charred wood that can be seen in some places at the top of the prineville. Some minor folding took place causing the anomalous dips observed in some Prineville exposures but not seen in overlying flows. Post-reversal time signaled the advent of a sequence of four basalt flows of the low Mgo geochemical type (Tygr 2 ), which were followed in rapid succession by two flows of the high Mgo geochemical type $\left(\right.$ Tygr $\left._{3}\right)$. The only significant stratigraphic break within this six-flow sequence occurs between the first two and the second two low Mgo flows. This is, however, the most prominent volcaniclastic interbed within the Clackamas River Columbia River basalts. The 
lighter coloration and generally coarser nature of this sedimentary deposit strongly suggests a change in the local volcanic regime, and possibly a change of source. Proximal volcanic facies such as lavas entered the area during preColumbia River Basalt time, but only distal volcanic facies such as mudflows and ash appear to have reached the area during this and other interflow periods. Some stream channels were cut into the flows beneath this interbed suggesting a shift from a degradational to an aggradational sedimentary environment over at least part of the area. Lakes continued to be present along the perimeter of the ancient highland causing the well-developed and widespread overlying pillow palagonite complex. The present of leaves shows that at least some vegetation was able to reappear.

The remaining four flows of the Grande Ronde Basalt, including two high Mgo flows $\left(\right.$ Tygr $_{3}$ ), are not separated by major interbeds even as far south as Third Creek in the Fish creek valley. This suggests that they may have entered the area in relatively rapid succession. The last of these flows heralded a time lapse between flood basalt episodes that was to last perhaps one million years.

The Vantage Member marks a break in time that was substantial enough for the top of the uppermost high MgO Grande Ronde to be weathered extensively. Forests reappeared and sediment was deposited over wide areas. The presence of some lahars indicates continued volcanic activity in the mountains to the south. Lakes also continued to be present 
and deposits were still very similar to the light-colored volcaniclastics that had already begun to appear in postreversal Grande Ronde time, except that fine-grained deposits began to be more abundant. Some basining appears to have occurred during this interval that was to have an effect on the distribution of subsequent flows.

This quiet of Vantage time was shattered when Frenchman Springs flows inundated the area, displacing lakes and devastating forests to produce the pillows and underlying woody deposits seen at the base of the section today. Each successive flow penetrated deeper into the foothills until additional subsidence in the basin to the north, or other factors, effectively excluded the rarely phyric and later Frenchman Springs flows from the perimeter of the highland. Post-Columbia River Basalt time saw the continued accumulation of similar volcaniclastic sedimentary and pyroclastic deposits (lower Sardine Formation) to those seen within the post-reversal Grande Ronde and Vantage. In time, these were joined by andesitic lavas of the upper sardine Formation. Structural and stratigraphic considerations, as of yet unknown, excluded further units of the Columbia River Basalt Group from the clackamas area except possibly as very localized intra-canyon flows. None have been located thus far.

Changes in base level in the area or other reasons caused the previous lacustrine regime to be replaced by an actively downcutting fluvial one. At least one ancestral 
Clackamas River canyon north of the present one was cut down to the high Mgo/low Mgo Grande Ronde level (Tygr ${ }_{3} /$ Tygr $_{2}$ ) and was subsequently filled by a sequence of intracanyon lavas and pyroclastics, the youngest of which has been labeled "Quaternary" by Peck, et al. (1964). The filling of this previous clackamas canyon displaced the river to the south. Also, the base level may have changed in this area of the Cascades subsequent to the above-mentioned intracanyon volcanics. This is indicated by down-cutting within the present canyon to over 400 meters below the previous one.

Columbia River Basalt time was, as previously stated, an episodic incursion into a pre-existing active volcanic area. The best indication of the nature of this latter activity is provided in the record of the interbeds. The meaning of these interflow units from the standpoint of time deserves further discussion.

The thicknesses of individual interflow units in the Clackamas River area depends upon such variables as distance from the degrading highland and the shape of the basin of deposition. The exact nature of the latter can only be speculated about, but bodies of water adjacent to the columbia River Basalt periphery were common in other areas such as the Cascades north of the Columbia River (Swanson, 1967). The geometry of the basalt mass as a whole was such that water was commonly ponded along its margins. Whether this was due to the gradient that provided the initial motive force for the basalt incursion, a meniscus effect, damming 
of tributary streams or other reasons, remains to be proven. The relative thicknesses of the interflow units compared to each other is perhaps a more important consideration. A vital observation that can be made is that relative thicknesses of these units is not a measure of the duration of the interflow time. The average time interval between flows is about 62,000 years after deducting one million years of Vantage time. This assumes somewhat unrealistically that episodes occurred at uniform intervals. Thus, ample time was available for episodes of Cascadian volcanism to have occurred. The composition of the lacustrine deposits is predominantly volcaniclastic so that extensive thicknesses of stratified beds of such materials could conceivably have accumulated very rapidly. Volcanic activity in the mountains would have resulted in denudation of slopes with subsequent increased erosion rates. Hence, the thick accumulations seen, particularly within the post-reversal Grande Ronde Basalt, probably mark episodes of higher volcanic activity rather than longer time intervals between flows. The greater the duration of interflow time, the greater the probability that a volcanic event could have taken place.

The Vantage Member represents what is probably the longest single interflow period within the Grande Ronde and Wanapum basalts (Mackin, 1961), and yet it is substantially thinner in most of the Clackamas River area than are other interbeds deposited during shorter time intervals. Thus, thickness of this unit does not appear to reflect elapsed 
time between flows. In the case of the Vantage, it is probable that it was deposited during a period of reduced volcanic activity. 
CHAPTER VI

\section{SUMMARY AND CONCLUSIONS}

Mapping of the flood basalts of the Columbia River Basalt Group was accomplished in the Clackamas River area using stratigraphic techniques developed for mapping these lavas within the Columbia Plateau. Many of these techniques were developed largely within the last ten years. Trace element and major oxide concentrations, paleomagnetism, lithology, petrography and various physical characteristics were used to identify the Grande Ronde and Wanapum Basalt within a 550-meter accumulation of Yakima Basalt Subgroup flows. Each of these two units was then subdivided into a number of subunits.

The Grande Ronde Basalt consists of five geochemically or paleomagnetically distinguishable subunits including, from oldest to youngest, the paleomagnetically normal (Tygr ${ }_{0}$ ) and reversed (Tygr ${ }_{1}$ ) low Mgo Grande Ronde Basalt, the reversed Prineville flows (Typv), and the normal low Mgo $\left(\right.$ Tygr $_{2}$ ) and high MgO $\left(\right.$ Tygr $\left._{3}\right)$ Grande Ronde Basalt. Collectively, these units constitute nearly $80 \%$ of the columbia River basalts in the Clackamas River area.

Interbeds are particularly well-developed within the Grande Ronde Basalt section where these flood basalts were flanked by an eroding but episodically active volcanic 
mountain range. The comparative composition of successively higher interbeds suggests that a transition from the volcanic sources of the Little Butte Volcanic Series to those of the Sardine Formation may have occurred in post-Prineville time. An interbed, separating the Grande Ronde Basalt from the Frenchman Springs Member of the Wanapum Basalt, is considered to be the lithostratigraphic equivalent of the Vantage Member of the Ellensburg Formation. Interflow units vary greatly in thickness at different stratigraphic horizons. The presence of distal volcanic facies, such as lahars and ash deposits, suggests that periods of volcanic activity during interflow times were more important in controlling the presence and thickness of these units than the amount of elapsed time.

The Frenchman Springs Member was found to consist of two lithologic flow types, including phyric and rarely phyric varieties. Upper and lower phyric flow groups are separated by an intervening rarely phyric flow group. The relative abundance of plagioclase glomerocrysts and other characteristics facilitated flow by flow correlation over much of the area.

Distribution of flow groups having similar characteristics is remarkably uniform across the clackamas River area, although thicknesses of individual flows vary considerably. Both the number of flows and the collective thickness of flow groups remain nearly constant except within the Frenchman Springs where the unit as a whole appears to thicken 
toward the north.

The structural character of the area is dominated by en echelon northwest-trending faults cutting a broadly warped and shallowly-dipping basalt sheet. Broad warping is indicated by dips that steepen downward and by the progressive exclusion of the upper Frenchman Springs Member flows from the area adjacent to the ancient highland. Northeast and north-south faults also occur but are in the minority. Both dip-slip and strike-slip faults are present with stratigraphic offsets commonly between 100 and 200 meters.

Disappearance of the basalts beneath younger deposits on the northwest and the appearance of underlying units on the southeast can now be largely attributed to incremental offsets on normal faults. The general northwest dip of the basalt reflecting Cascadian uplift is only a partial explanation for the distribution of the Columbia River basalt exposures.

The general uniformity of the gently dipping basalt sheet is disrupted along the northeast margin of the area. Folding occurs near the South Fork of Roaring River where steep dips greater than $20^{\circ}$ are seen along the limbs of a northwest trending anticline. Faulting along the flanks of this fold has dropped the crest down as a block. Folding is also implied by the steep dips observed near Lake Harriet where significant faulting is again present.

Complimentary northwest and northeast trends, uniformly vertical or near vertical fault planes, and northwest 
trending right-lateral strike-slip faults are all characteristics that are consistent with a stress model of northsouth compression and east-west extension. Moreover, the pattern of northwest trending en echelon faults is consistent with empirically derived patterns for surface faulting resulting from right-lateral strike-slip motion at depth. A genetic relationship between this zone and either the en echelon Brothers Fault zone or Portland Hills trend remain to be proven. However, similarities in trend, overall pattern, and the type of faulting make such a connection possible if not highly probable. 


\section{REFERENCES CITED}

American Commission on Stratigraphic Nomenclature, 1961, Code of stratigraphic nomenclature: Am. Assoc. Petroleum Geologists Bull., v. 45, p. 645-665.

Atlantic Richfield Handford Company, 1976, Preliminary Feasibility study of storage of Radioactive wastes in Columbia River Basalts: ERDA Rept. ARH-ST-137, v. I, (text, 168 p.) and v. 2 (appendixes, 264 p.)

Barnes, F. F., and Butler, W., 1930, The structure and stratigraphy of the Columbia River Gorge and Cascade mountains in the vicinity of Mount Hood: Eugene, University of Oregon, M.S. thesis, $73 \mathrm{p}$.

Beeson, M. H., Johnson, A. G., and Moran, M. R., 1975, Portland Environmental Geology - Fault Identification, Portland State University, Oregon, $107 \mathrm{p}$.

Beeson, M. H., Moran, M. R., and olson, F. L., 1976a, Geochemical data on Columbia River basalt stratigraphy in western Oregon: Geol. Soc. America Abs. with programs, v. 8, no. 3, p. 354.

Beeson, M. H., Bentley, R. D., and Moran, M. R., 1976b, Preliminary correlation of Lower Yakima Basalt flows in western Oregon with the type area in central Washington: Geol. Soc. America Abs. with programs, v. 8, no. 3, p. 355 .

Bentley, R。D., 1977, Stratigraphy of the Yakima basalts and structural evolution of the Yakima Ridges in the western Columbia Plateau, in Brown, E. H. and Ellis, R. Co, Geologic excursions in the Pacific Northwest: Bellingham Dept. of Geol., W. Wash. Univ., p. 339-389.

Billings, M. P., 1972, Structural Geology, Prentice-Hall, Inc., Englewood Cliffs, N. J., 606 p.

Bingham, J. W. and Grolier, M。 J., 1966, The Yakima Basalt and Ellensburg Formation of south-central Washington: U.S. Geol. Survey Bull. 1224-G, 15 p.

Brock, M. R. and Grolier, M. J., 1973, Chemical analyses of basalt samples from the Columbia plateau, Washington, oregon, and Idaho: U.S. Geol. Survey open-file report. 
Callaghan, E. and Buddington, A. F., 1938, Metalliferous mineral deposits of the Cascade Range in oregon: U.S. Geol. Survey Bull. 893.

Diery, H. D., 1967, Stratigraphy and structure of Yakima Canyon between Roza Gap and Kittitas Valley, central Washington: Ph.D. thesis, University of Washington, Seattle, $116 \mathrm{p}$.

Diery, H. D. and McKee, B., 1969, Stratigraphy of the Yakima Basalt in the type area: Northwest Science, v. 43, no. 2, p. 47-64.

Flanagan, F. J., 1973, 1972 values for international geochemical reference samples: Geochemica et Cosmochimica Aeta, v. 37, p. 1189-1200.

Kienle, C.F., 1971, The Yakima Basalt in western oregon and Washington: Ph.D. thesis, University of California, Santa Barbara, $171 \mathrm{p}$.

Mackin, J. H., 1961, A stratigraphic section in the Yakima Basalt and Ellensburg Formation in south-central Washington: Wash. Div. Mines and Geology Rept. Inv. $19,45 \mathrm{p}$.

McKee, E. H., Swanson, D. A., and Wright, T. L., 1977, Duration and volume of Columbia River Basalt volcanism, Washington, Oregon and Idaho: Geol. Soc. America Abs. with programs, v. 9, no. 4, p. 463-464.

Nathan, S. and Fruchter, J. R., 1974, Geochemical and paleomagnetic stratigraphy of the Picture Gorge and Yakima basalts (Columbia River Group) in central Oregon: Geol. Soc. America Bull., v. 85, p. 63-76.

Peck, D. L., Griggs, A. B., Schlicker, H. G., Wells, F. G., and Dole, H. M., 1964, Geology of the central and northern parts of the western Cascade Range in Oregon: U.S. Geol. Survey Prof. Paper 449, 56 p.

Seims, B. A., Bush, J. H., and Crosby, J. W., III, 1974, $\mathrm{TiO}_{2}$ and geophysical logging criteria for Yakima Basalt correlation, Columbia Plateau: Geol. Soc. America Bull., v. 85, p. 1061-1068.

Swanson, D. A., 1967, Yakima Basalt of the Tieton River area, south-central Washington: Geol. Soc. America Bull., v. 78, p. 1077-1110. 
Swanson, D. A. and Wright, T. L., 1978, Some important facts and inferences concerning the Columbia River Basalt Group: Tectonics and seismicity of the Columbia Plateau workshop, Seattle, Washington.

Swanson, D. A., Wright, T. L。, Hooper, P. R., and Bentley, R. D. . in press, Revisions in stratigraphic nomenclature of the Columbia River Basalt Group: U.S. Geol. Survey Bull.

Taylor, T. L., 1976, The basalt stratigraphy and structure of the Saddle Mountains of south-central Washington: M.S. thesis, Washington State Univ., Pullman, $116 \mathrm{p}$.

Uppuluri, V。R., 1973, A stratigraphic and compositional study of basalts of the Columbia River Group near Prineville, central oregon: M.S. thesis, Univ. of Oregon, Eugene, $87 \mathrm{p}$.

1974, Prineville chemical type: a new basalt type in the Columbia River Group: Geol. Soc. America Bull., v. 85, p. 1315-1318.

Waters, A. C., 1961, Stratigraphic and lithologic variations in the Columbia River Basalt: Am. Jour. Sci., v. 259, p. 283-611.

Watkins, N. D. and Baksi, A. K., 1974, Magnetostratigraphy and oroclinal folding of the Columbia River, Steens and owyhee basalts in oregon, Washington and Idaho: Am. Jour. of Sci., v. 274, p. 148-189.

Wells, F. G. and Peck, D. L., 1961, Geologic map of Oregon West of the 12lst meridian: U.S. Geol. Survey Misc. Inv. Map I-325, scale 1:500,000.

Wheeler, H. E. and Mallory, V. S., 1970, Oregon Cascades in Relation to Cenozoic Stratigraphy, in Gilmour, E. H. and Stradling, D., eds., Proceedings of the second Columbia River Basalt symposium: Cheney, Eastern Washington State College, p. 97-125.

Wright, T. L., Grolier, M. J., and Swanson, D. A., 1973, Chemical variation related to the stratigraphy of the Columbia River Basalt: Geol. Soc. America Bull., v. 84, p. 371-386. 
APPENDIX A

\section{GEOCHEMICAL CONTROL SECTIONS}

The locations, characteristics and sample localities for five measured stratigraphic sections are presented in this appendix. Three figures pertain to each section, including a locality map, a photograph with overlay and a cross-sectional sketch. Sample localities appear on both the photographic overlay and cross-sectional sketches. Sample numbers correspond to the geochemical sample numbers listed in Tables VII and VIII, Appendixes C and D.

Unit symbols shown on figures of this appendix correspond to those used on the geologic map, Figure 12 . Magnetic polarities are indicated in parentheses with (N) and (R), representing normal and reversed polarity respectively. 


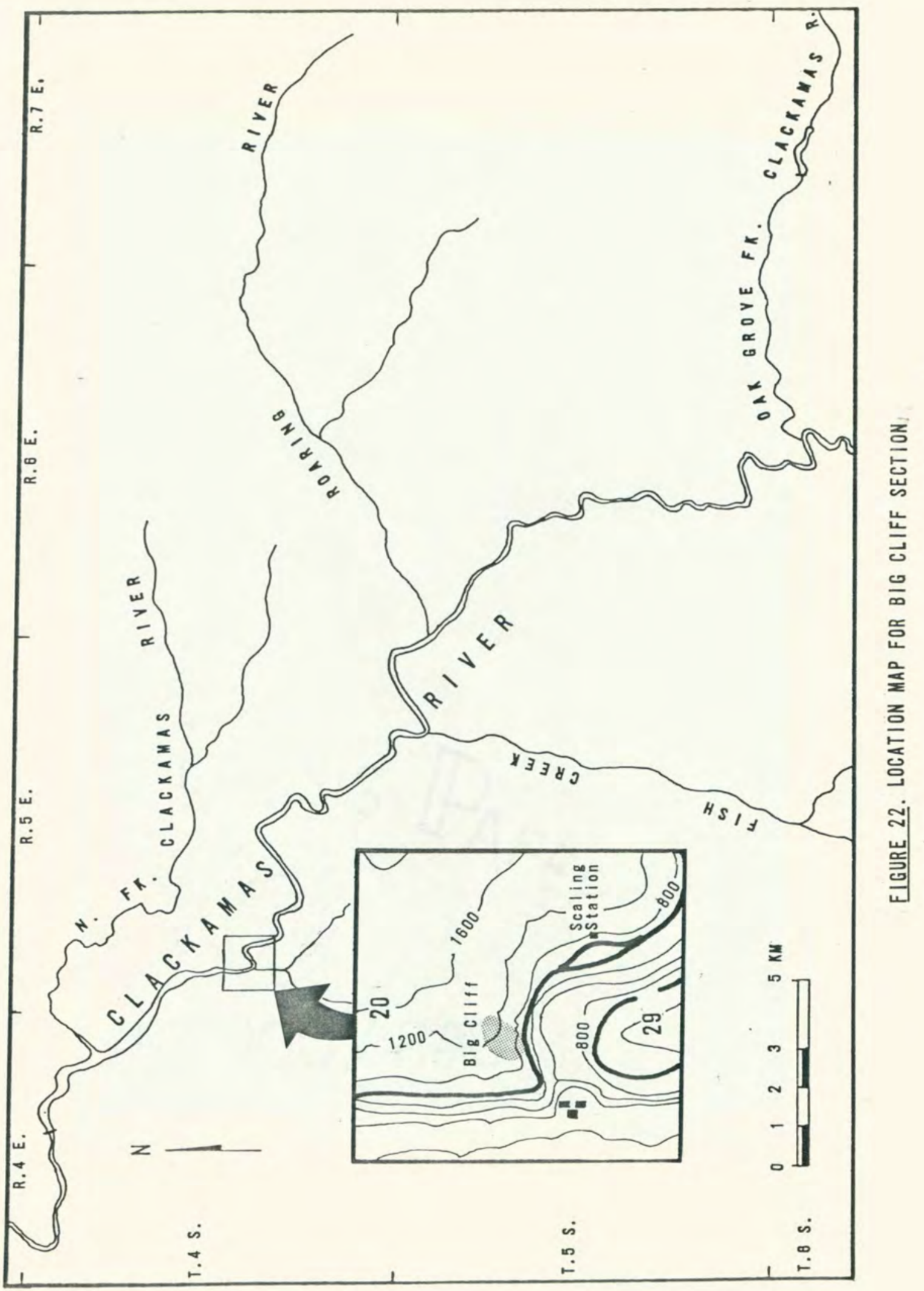




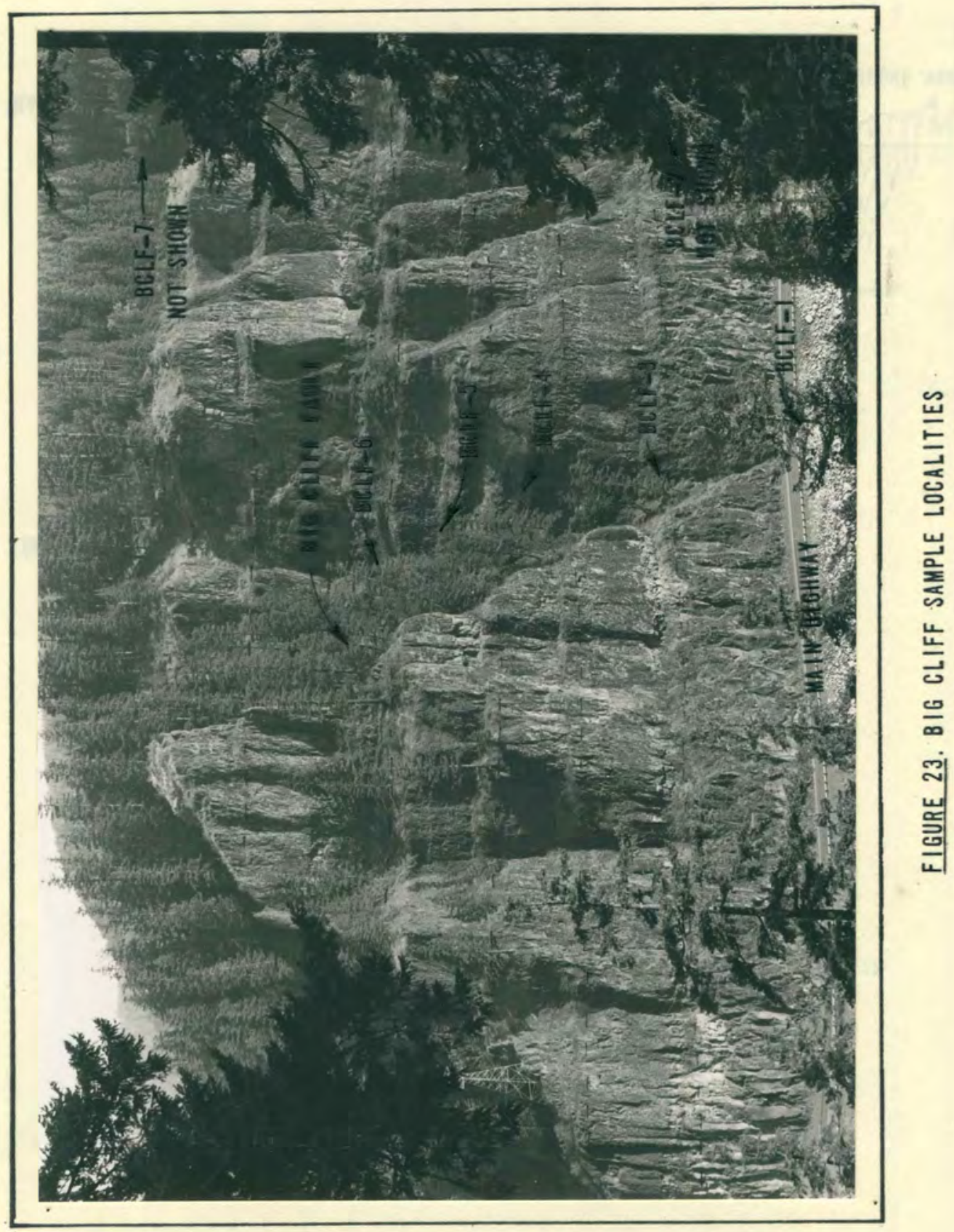




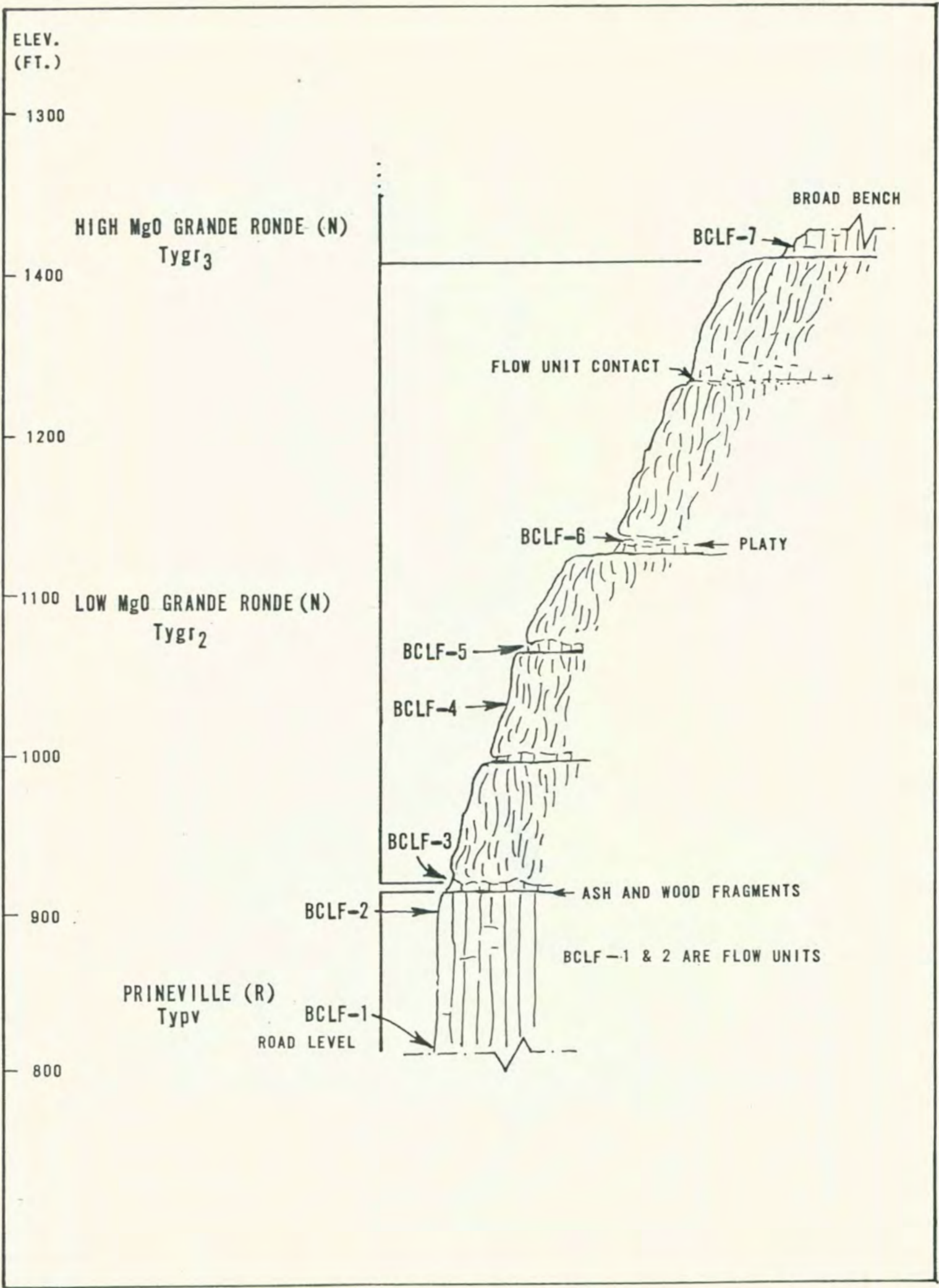




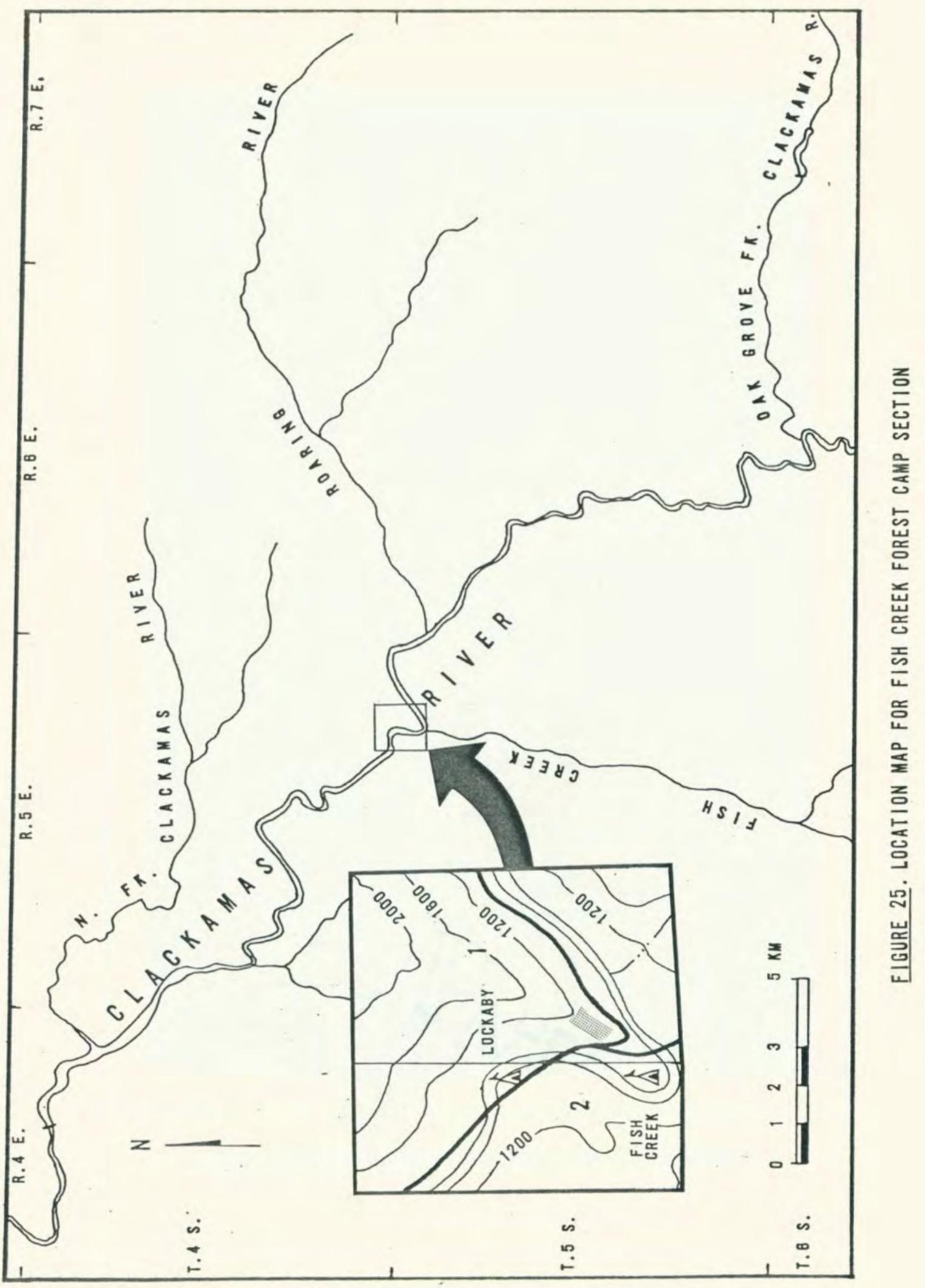




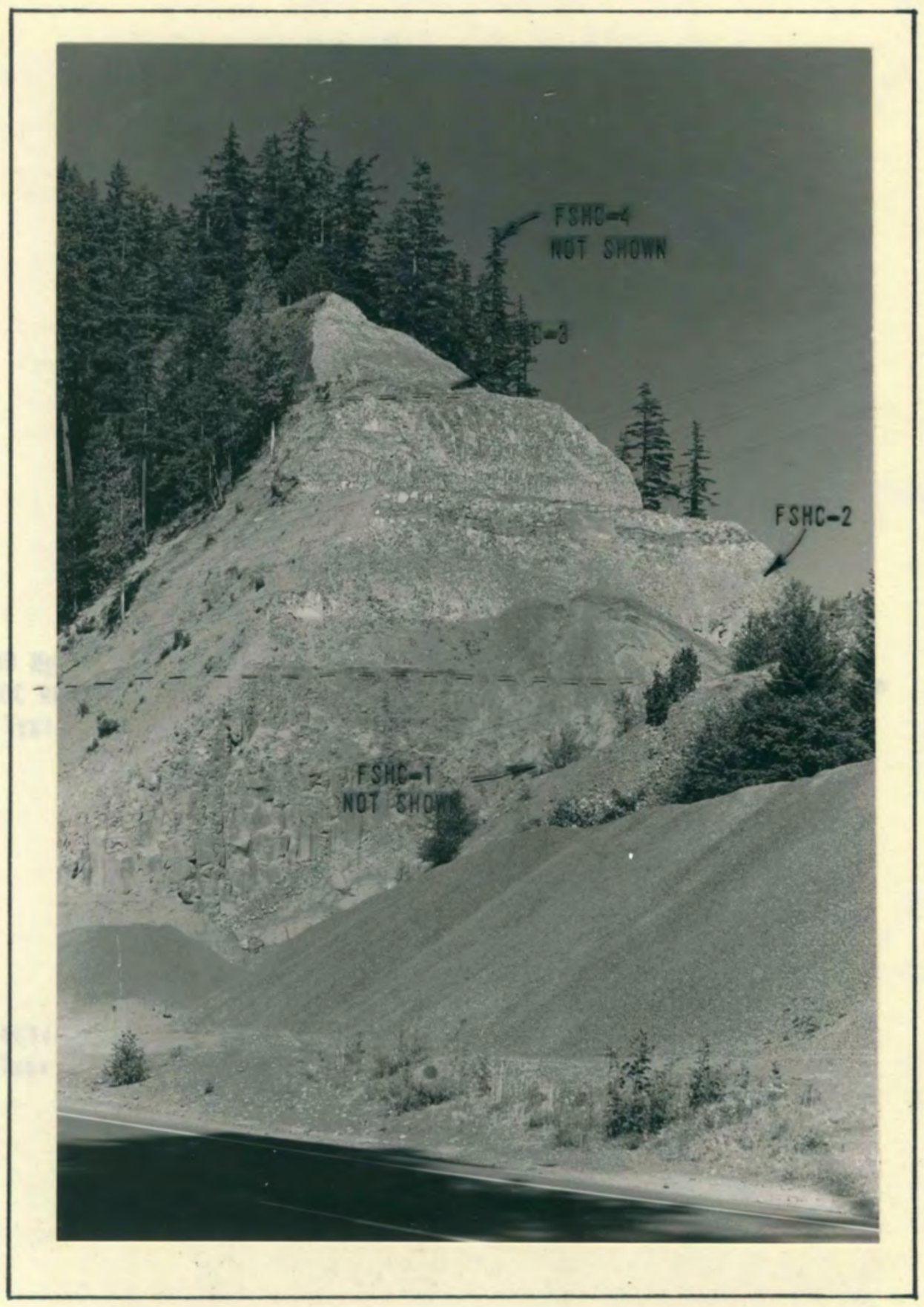

FIGURE 26. FISH CREEK FOREST CAMP SAMPLE LOCALITIES 
ELEV.

(FT.)

$-1300$

$-1200$

GRANDE RONDE(N)

( Tyg 2 )

$-1100$

$-1000$

$-900$

PRINEVILLE(R)

(Typr)
LOW MgO

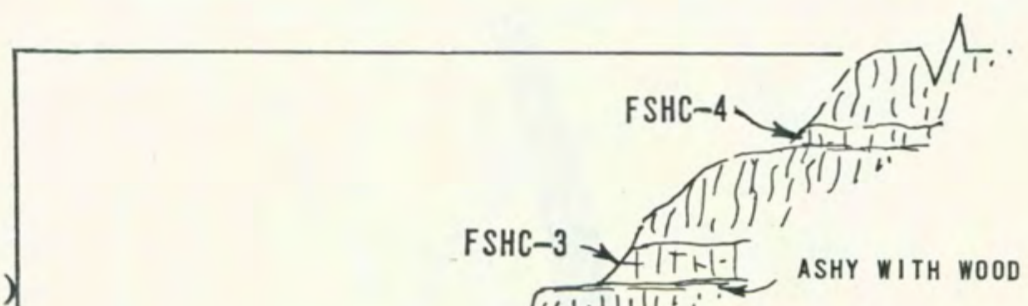
(1)1111!: $\left(\begin{array}{lll}1 & 1 \\ 1,11 & 1\end{array} \mid\right.$

1) 111 1,11

1).

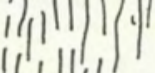

FSHC-2

$(1,1) 10$

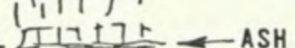

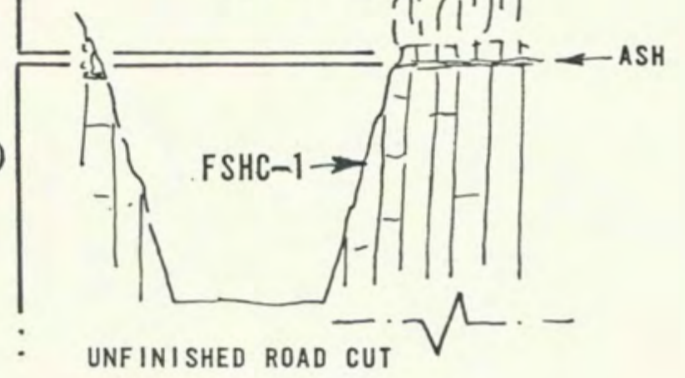




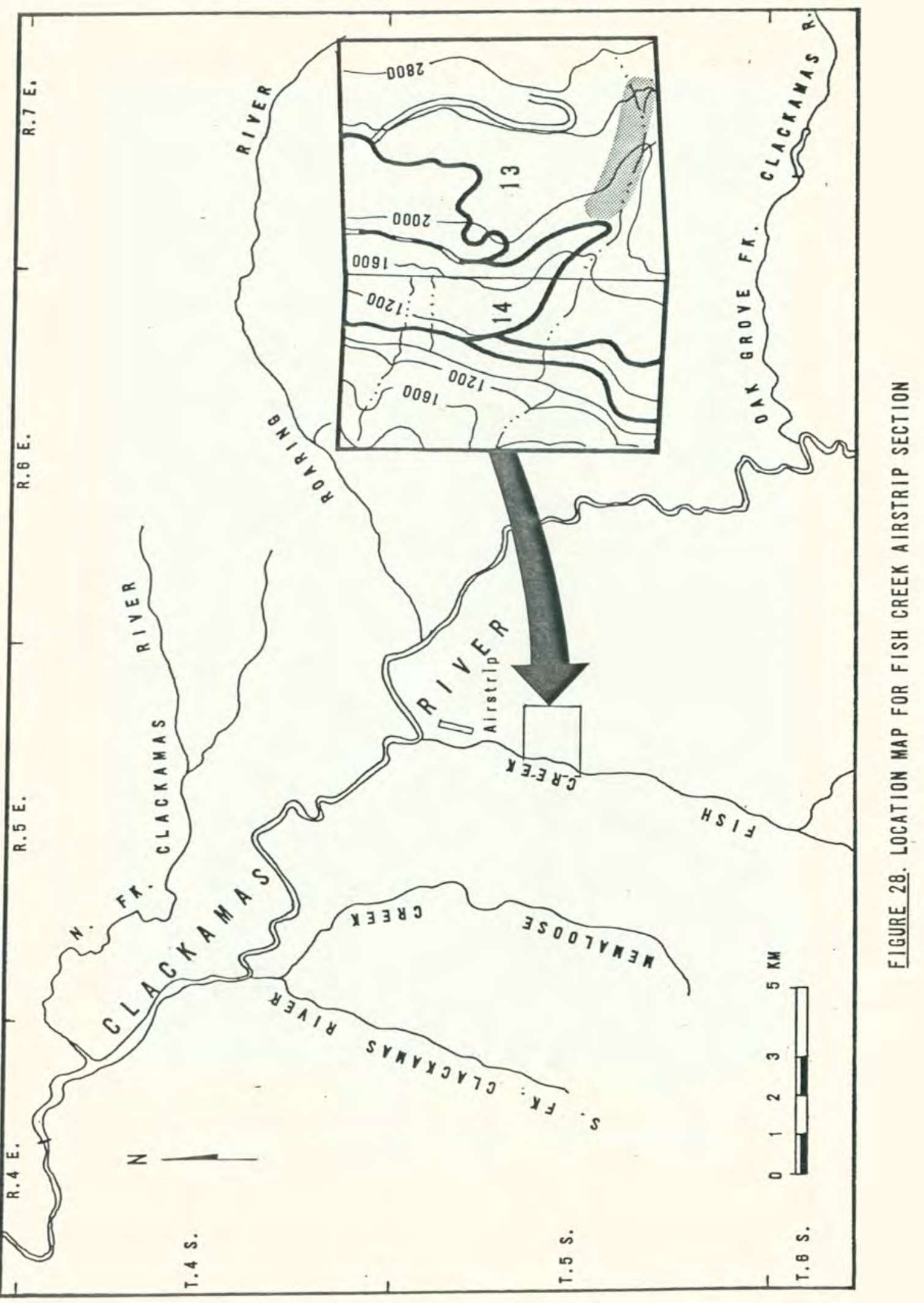




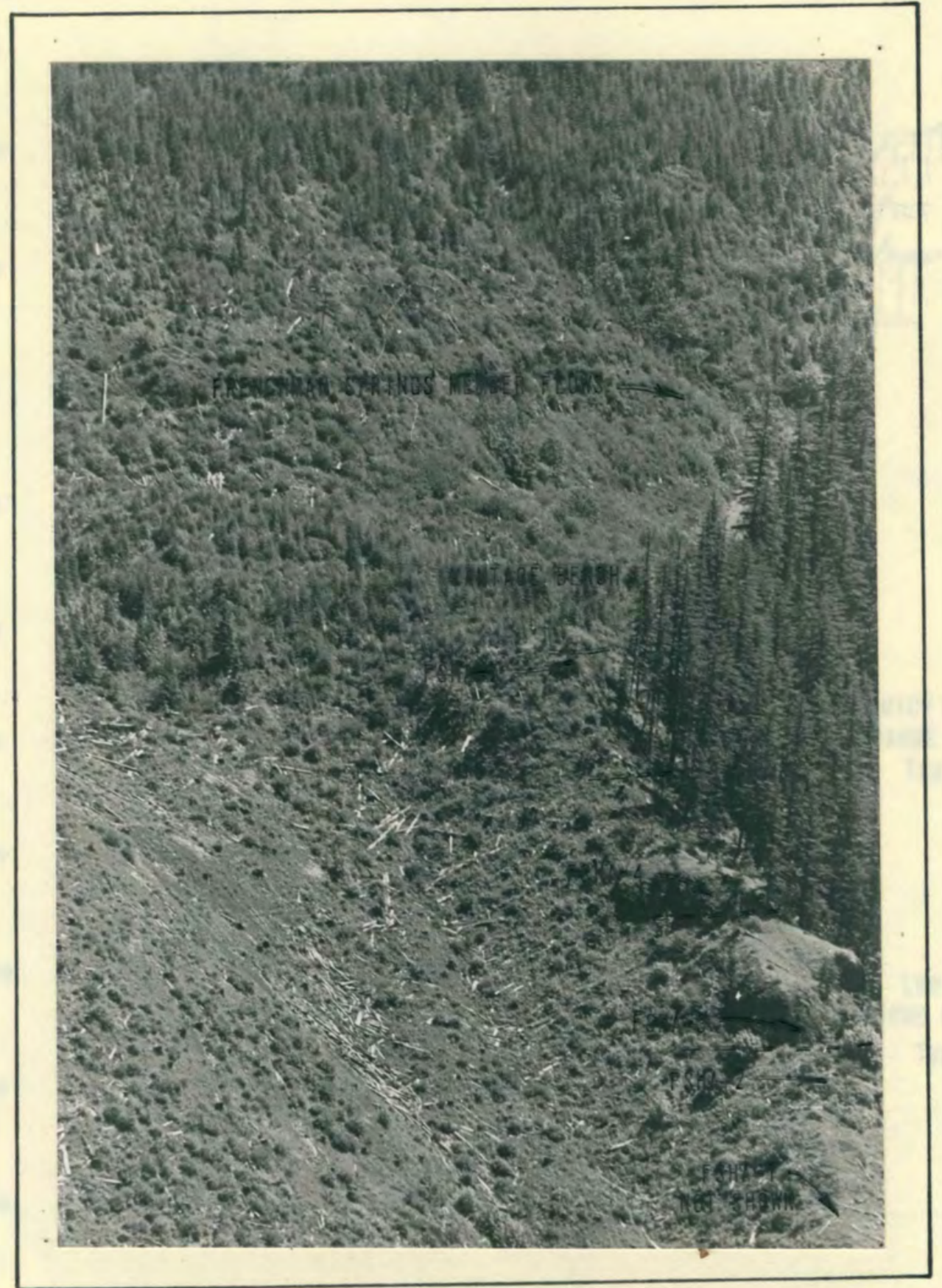

FIGURE 29. FISH CREEK AIRSTRIP SAMPLE LOCALITIES 
ELEV.

(FT.)

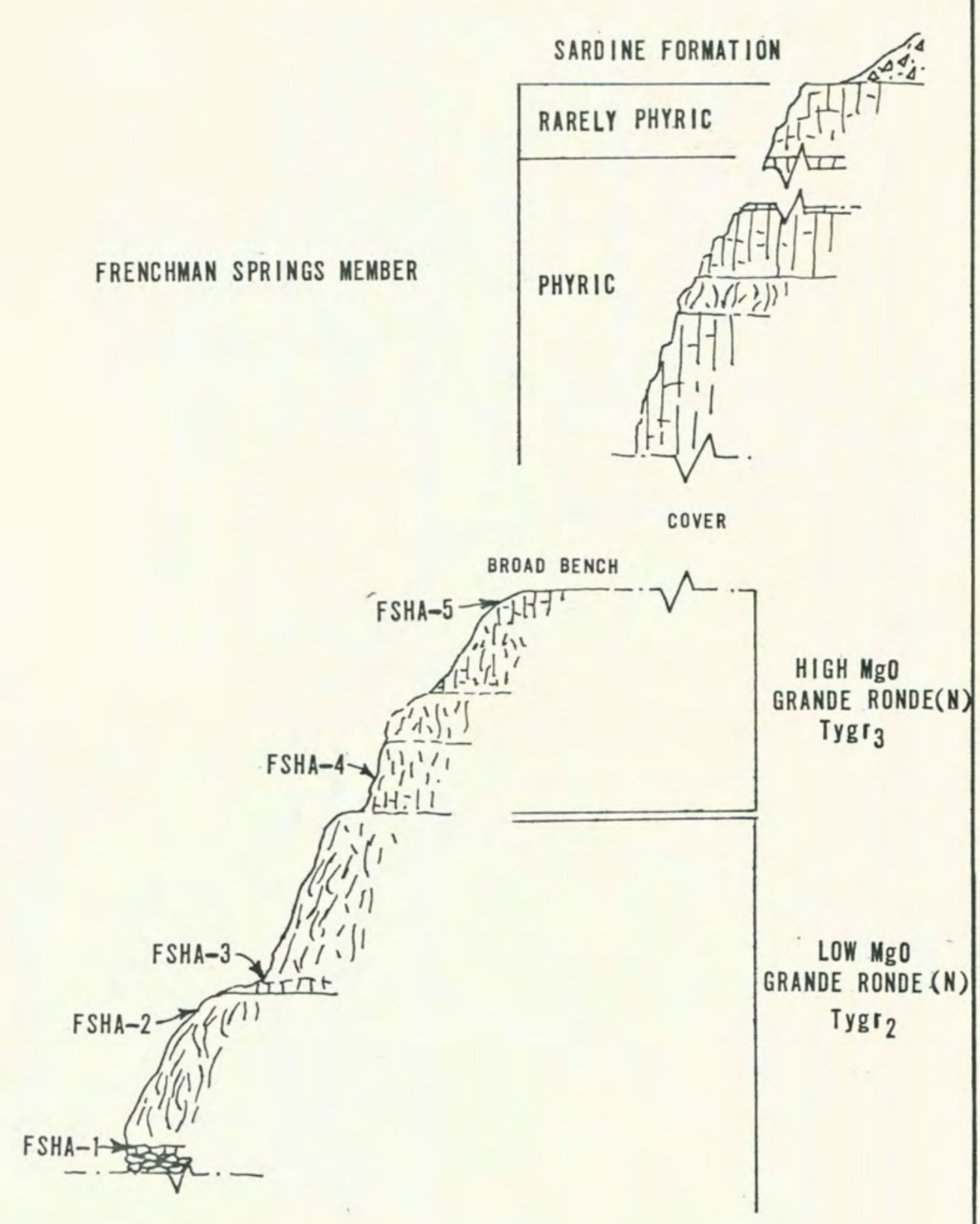

-2200
-2100

\section{FRENCHMAN SPRINGS MEMBER}

-2400
-2300

$-1900$

$-1800$

$-2000$

$-1700$

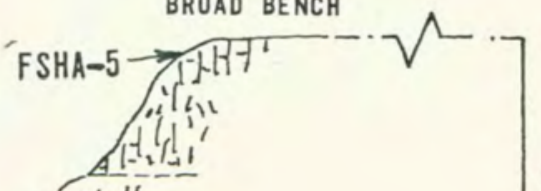

HIGH MgO

ANDE RONDE(N)

$\mathrm{yg}_{3}$

LOW MgO

Tygr $_{2}$ 


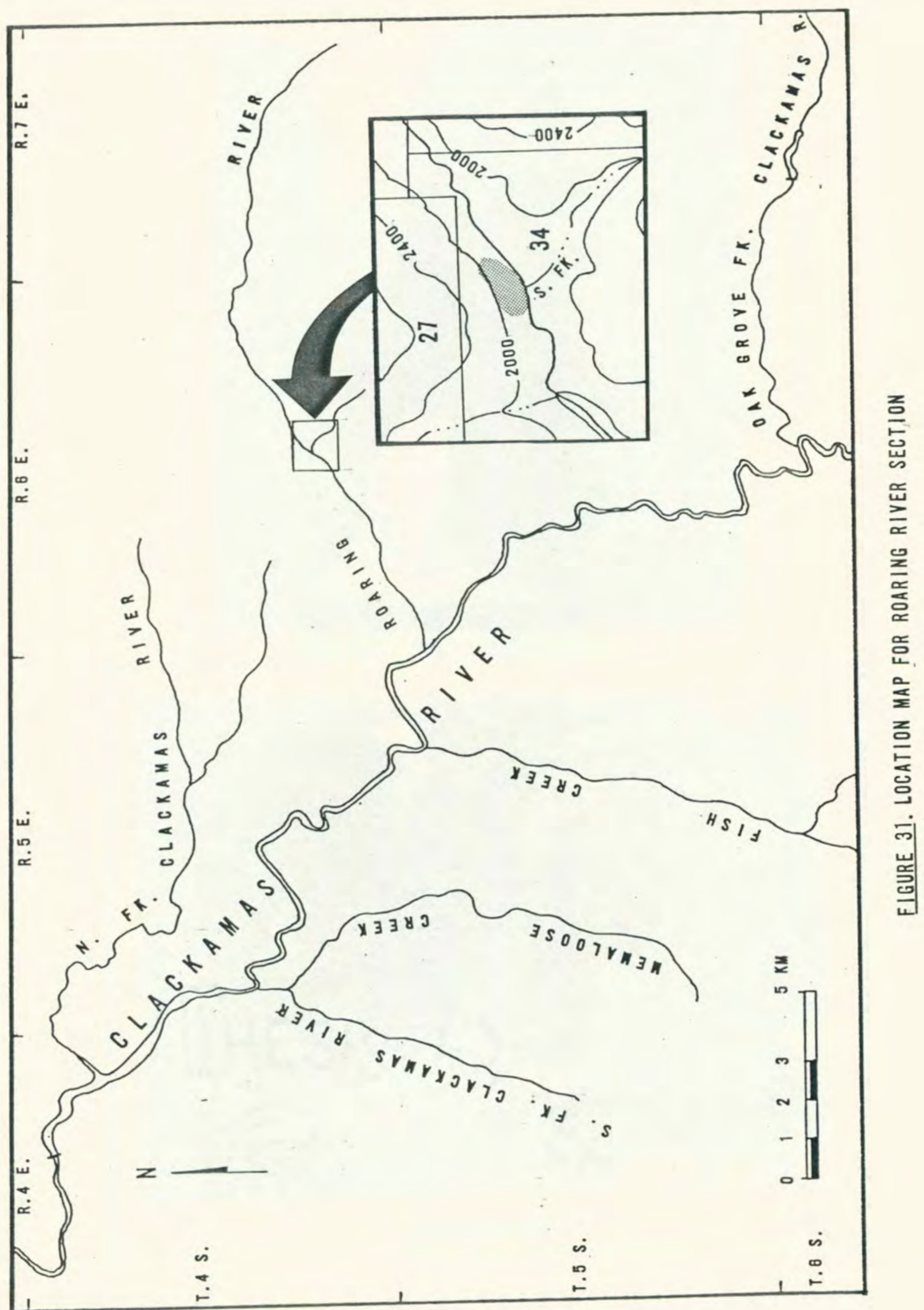




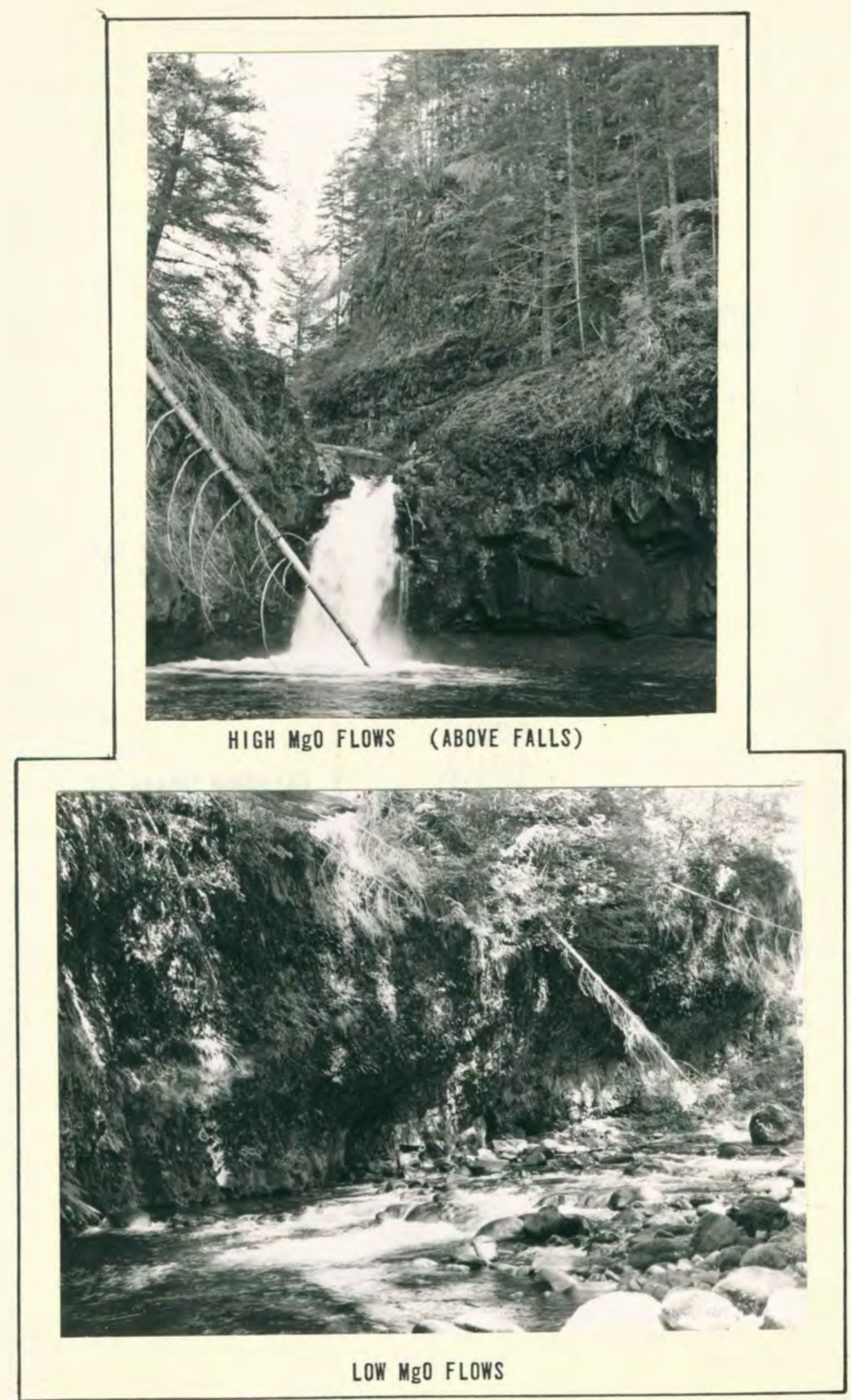

FIGURE 32. FLOWS SAMPLED IN ROARING RIVER AREA 
ELEV.

(FT.)

$-2000$

$-1900$

$-1800$

$-1700$

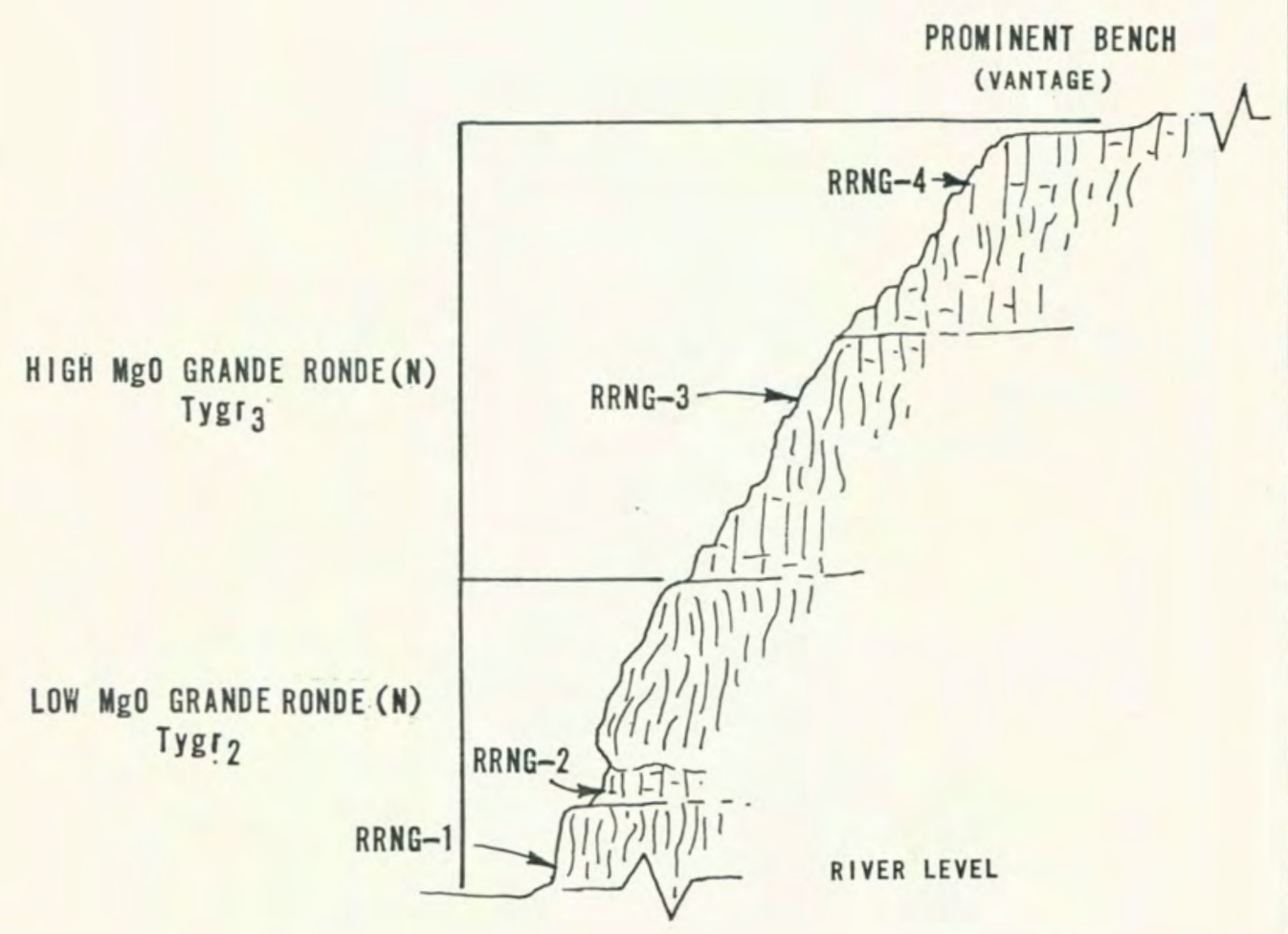

FIGURE 33. ROARING RIVER STRATIGRAPHIC SECTION 


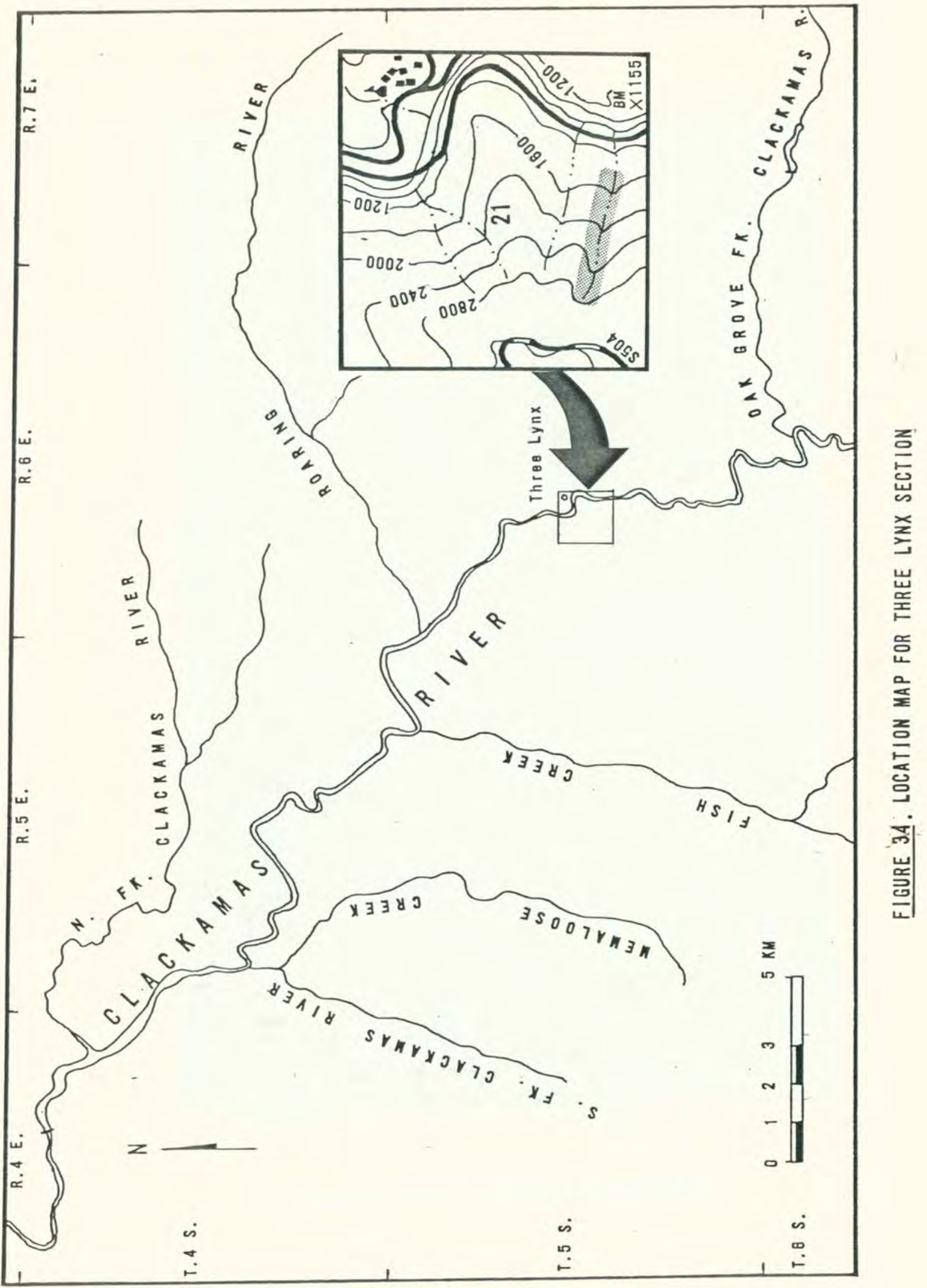




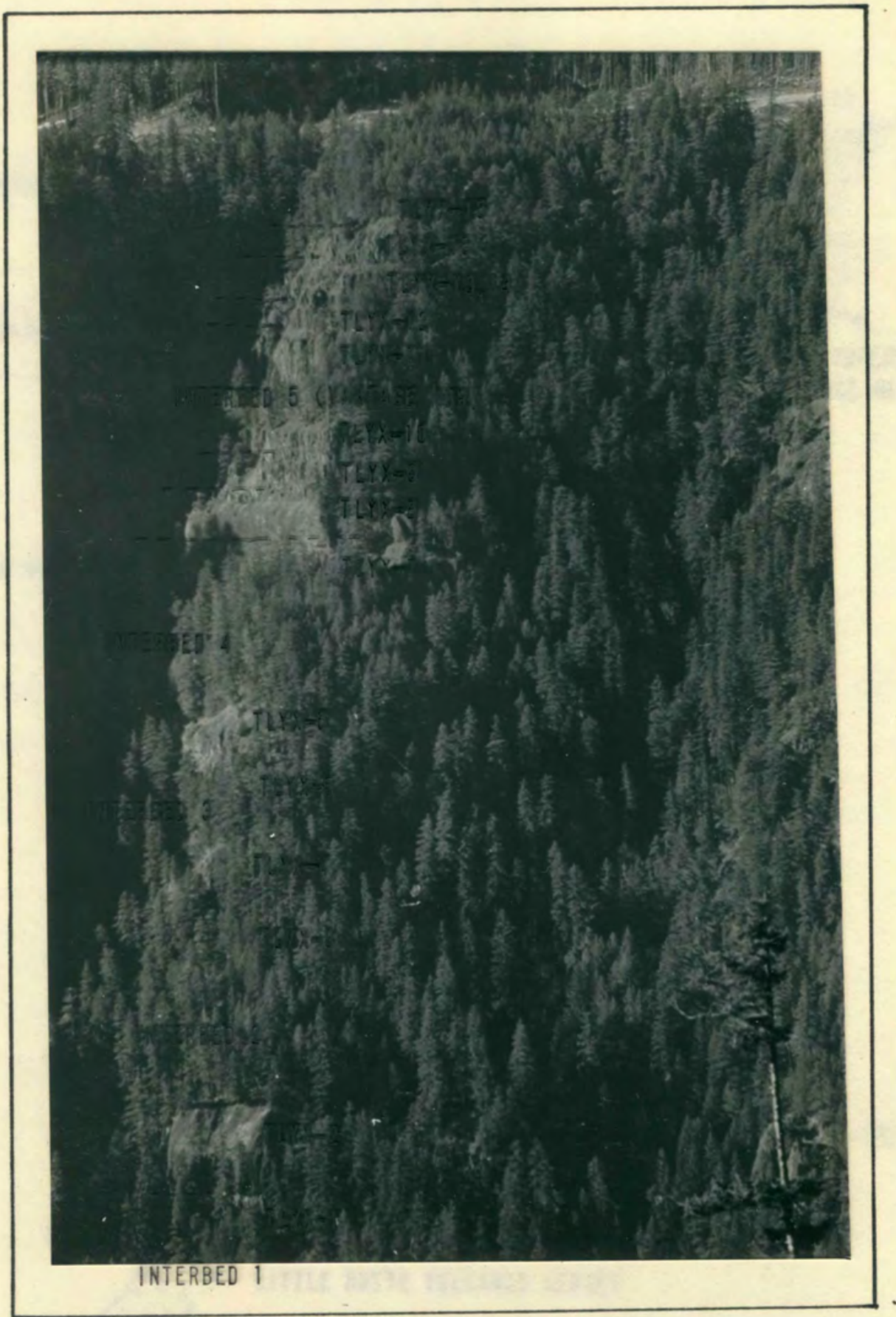

FIGURE 35. THREE LYNX SAMPLE LOCALITIES 


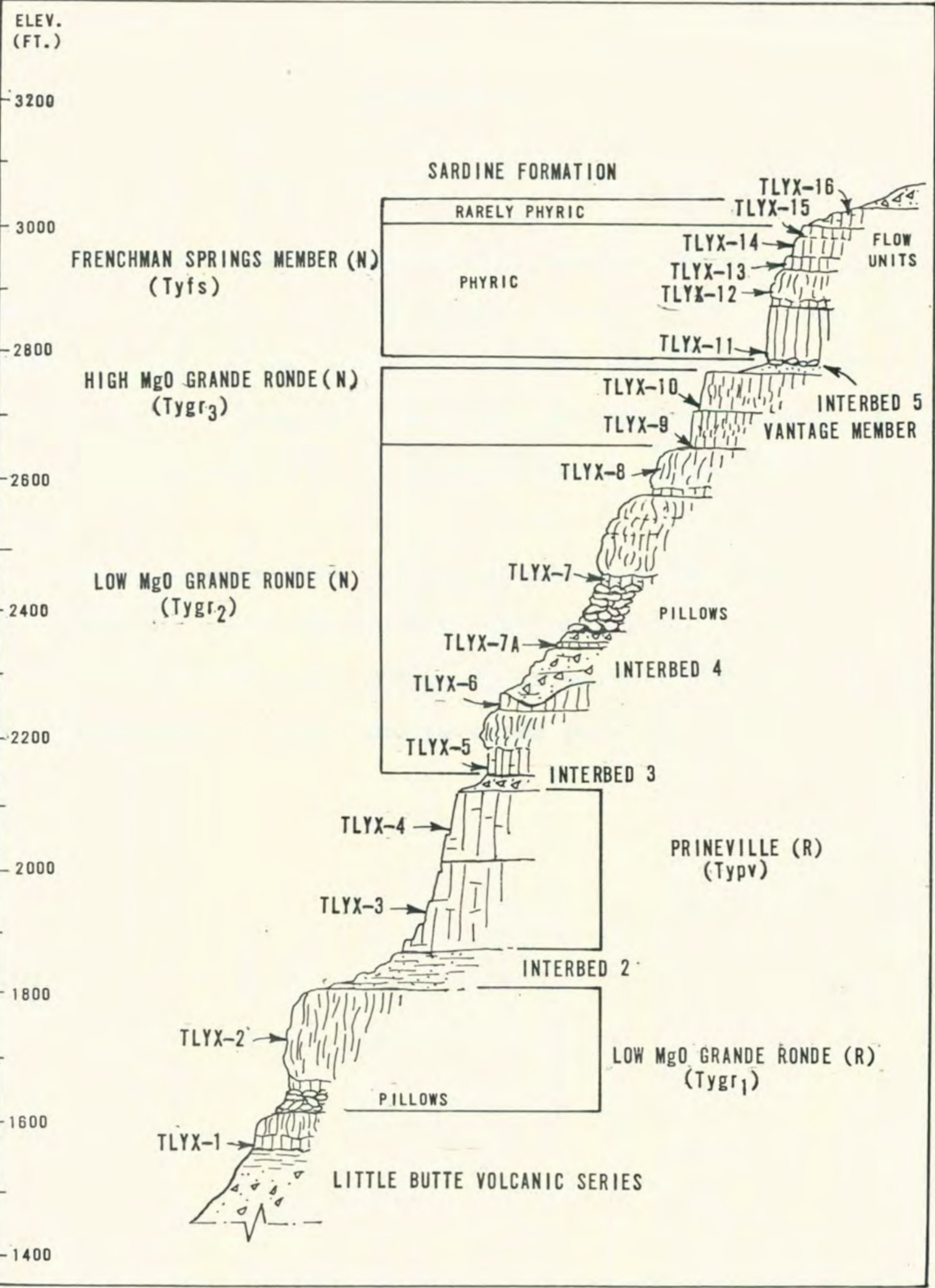

FIGURE 36. THREE LYNX STRATIGRAPHIC SECTION 


\section{APPENDIX B \\ OTHER STRATIGRAPHIC SECTIONS}

Details of stratigraphic sections are presented in this appendix. Each is numbered in order to facilitate indexing. Figure 37 and 38 are index and locality maps; Figures 39 through 49 are cross-sectional sketches drawn to scale for each of the sections in the same sequence presented in the Index.

Unit symbols shown on cross-sectional sketches correspond to those used on the geologic map, Figure 12 . Magnetic polarities are indicated in parentheses with (N) and (R) representing normal and reversed polarity respectively. 


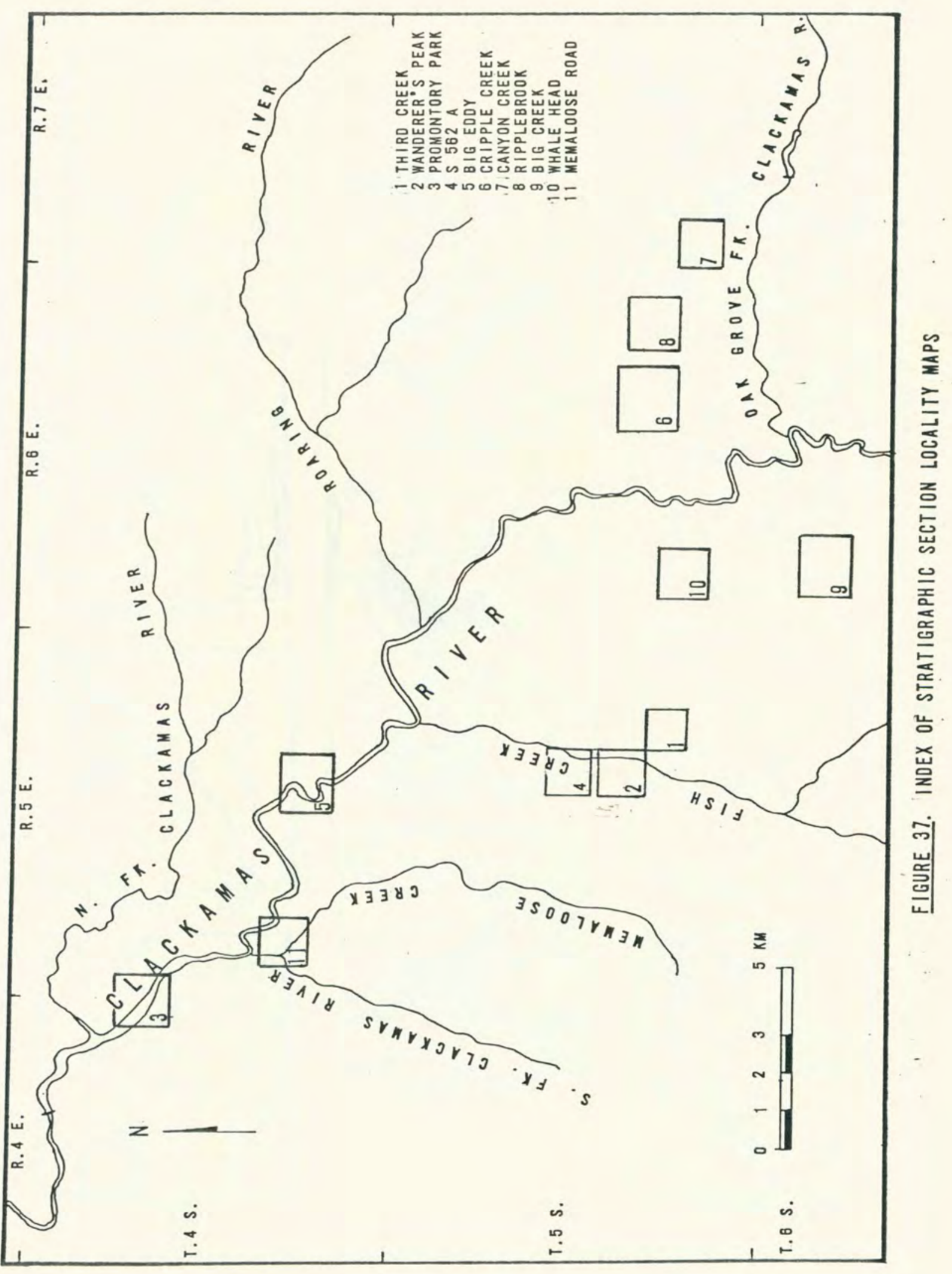




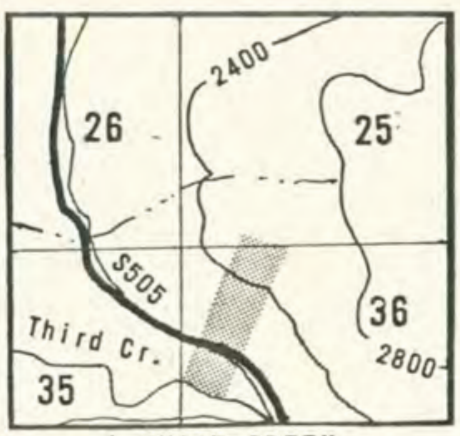

1. THIRD CREEK

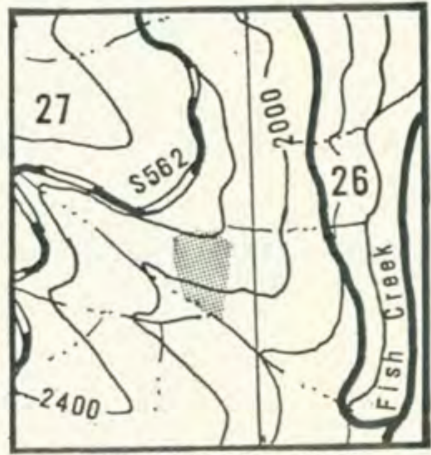

2. WANDERERS PEAK

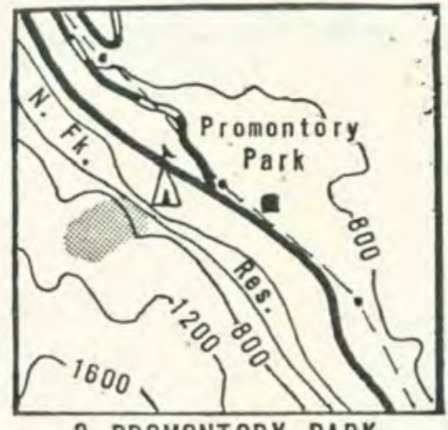

3. PROMONTORY PARK

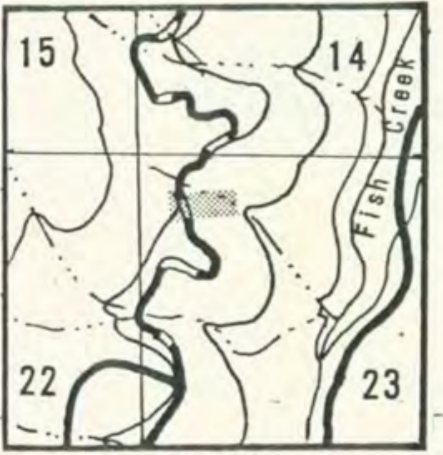

4. S $562 \mathrm{~A}$

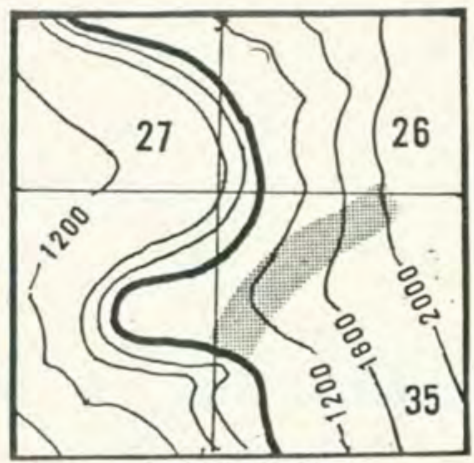

5. BIG EDDY

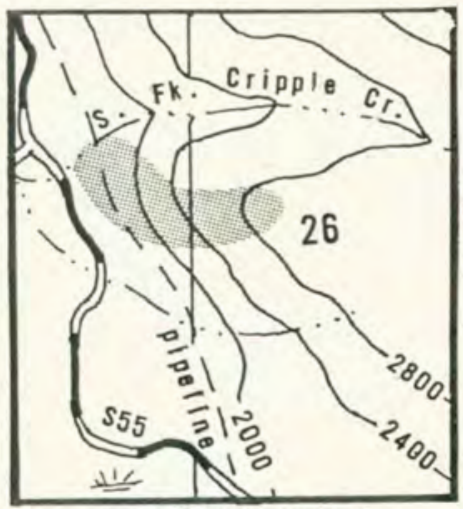

6. CRIPPLE CREEK

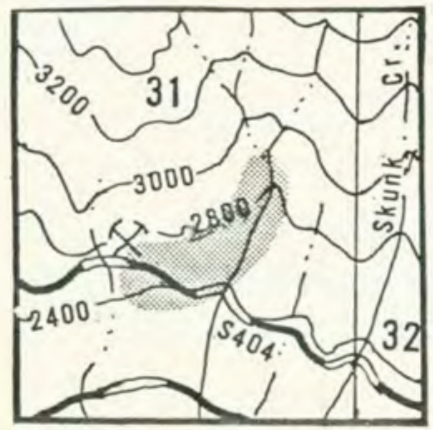

7. CANYON CREEK

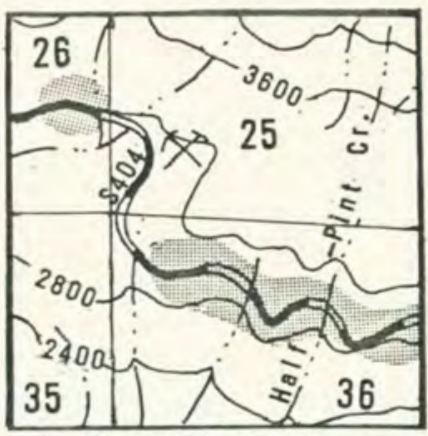

8. RIPPLEBROOK

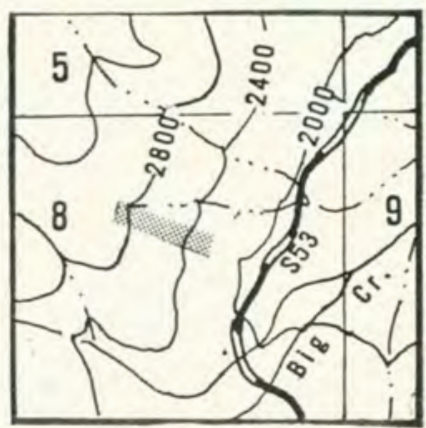

9. BIG CREEK

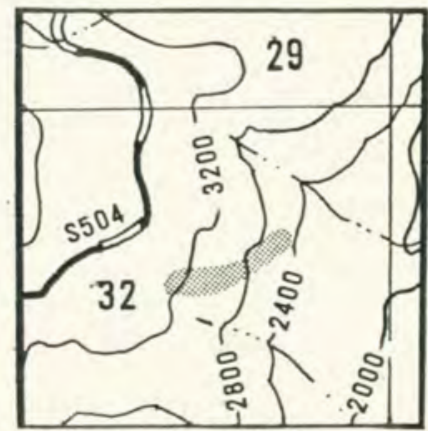

10. WHALE HEAD

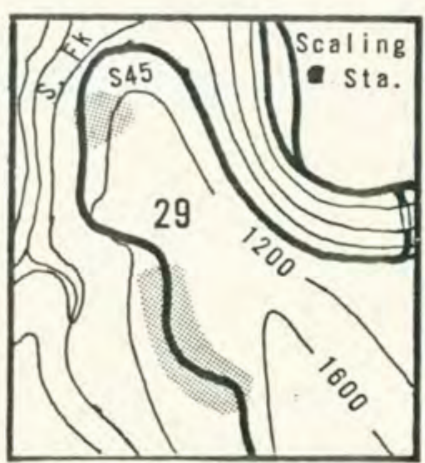

11. MEMALOOSE ROAD 
ELEV.

(FT.)

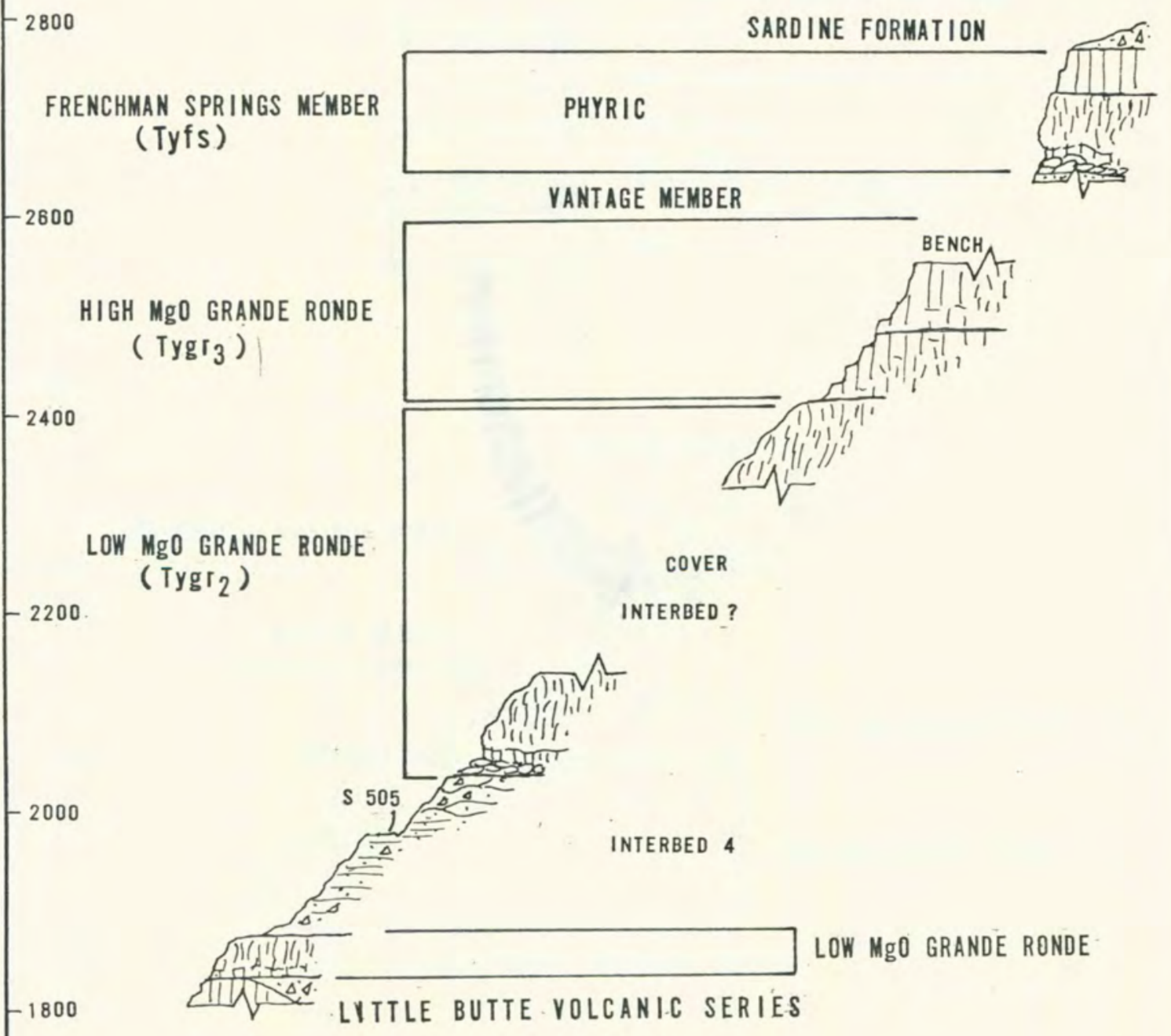

FIGURE 39. THIRD CREEK STRATIGRAPHIC SECTION 
ELEV.

(FT.)

2400

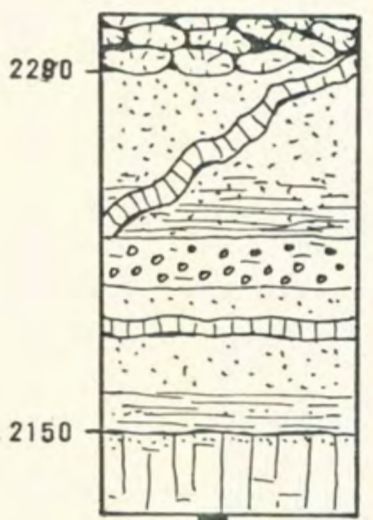

PILLOWS TyfS

ANDESITE DIKE

TUFFACEOUS LIGHT GRAY TO WHITE

SANDSTONE GRADING INTO BROWN

STRATIFIED SOFT SILTSTONE

PEBBLE CONGLOMERATE IN A SILTY MATRIX

ANDESITE SILL

GRAY SANDSTONE

SANDSTONE WITH INTERBEDDED

YELLOW GRAY ARGILLITE

$\mathrm{Tyg}_{3}$

$-2300$

FRENCHMAN SPRINGS MEMBER

(Tyts)

VANTAGE MEMBER

(SARDINE FORMATION)

2200

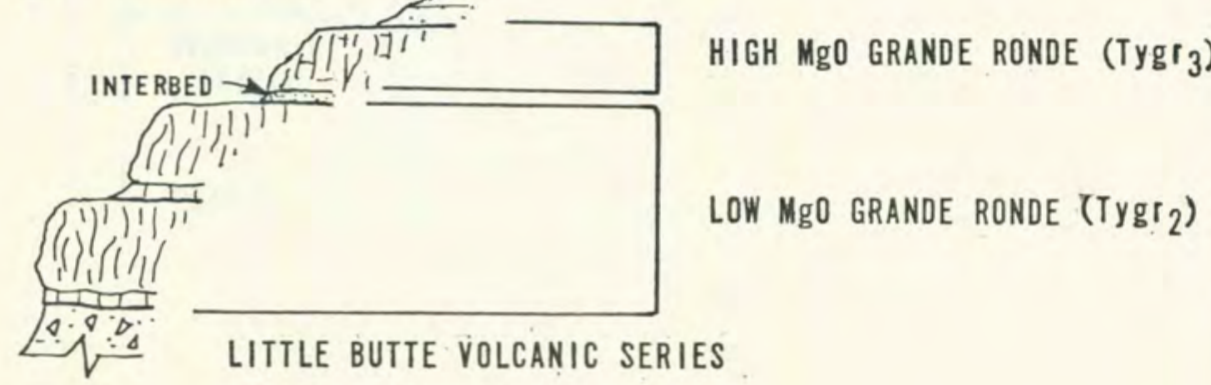

SARDINE FORMATION COVER

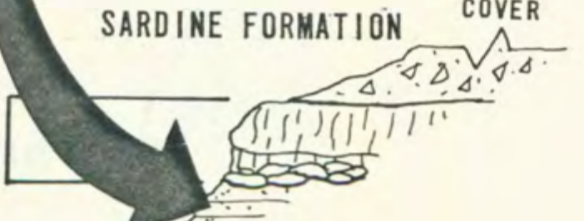

2100

LITTLE BUTTE VOLCANIC SERIES 


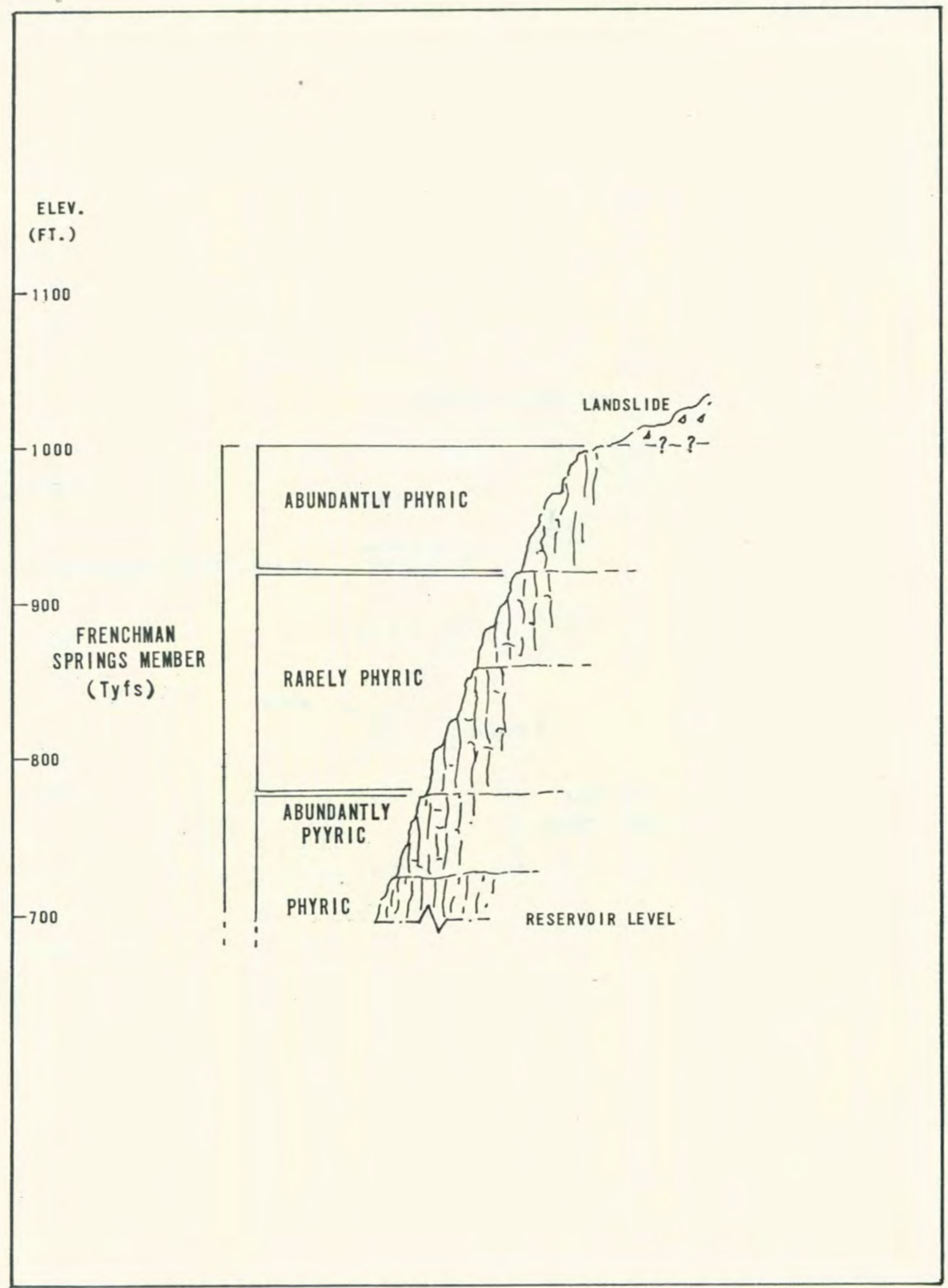

FIGURE 41: PROMONTORY PARK STRATIGRAPHIC SECTION 
ELEY.

(FT.)

$-2100$

$-2000$

\section{SARDINE FORMATION}

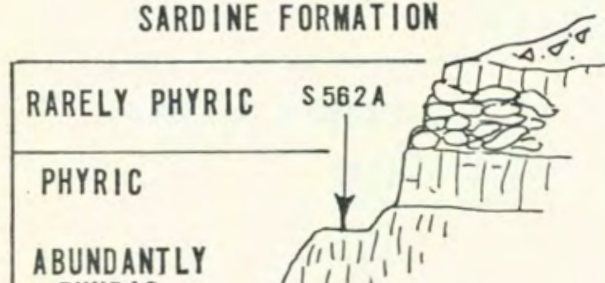

FRENCHMAN SPRINGS MEMBER

$-1900$

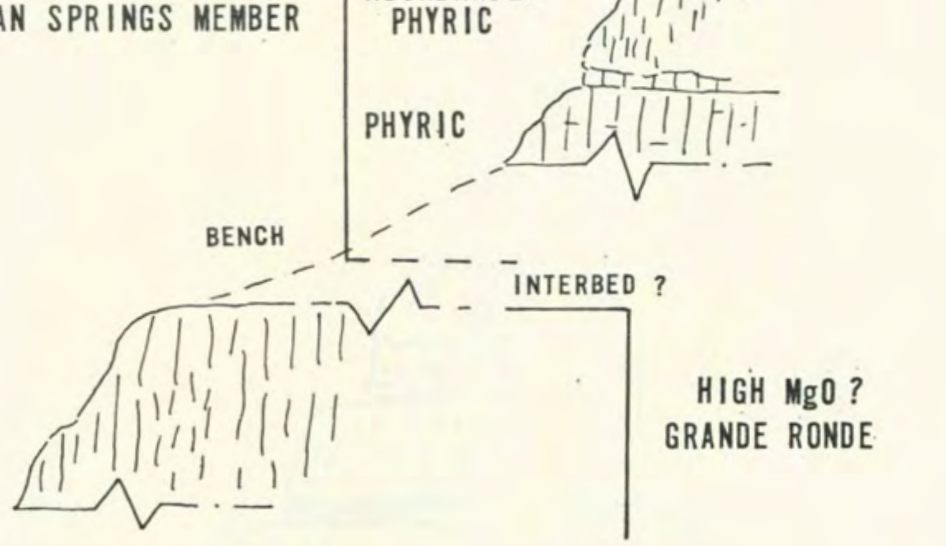

$-1700$ 


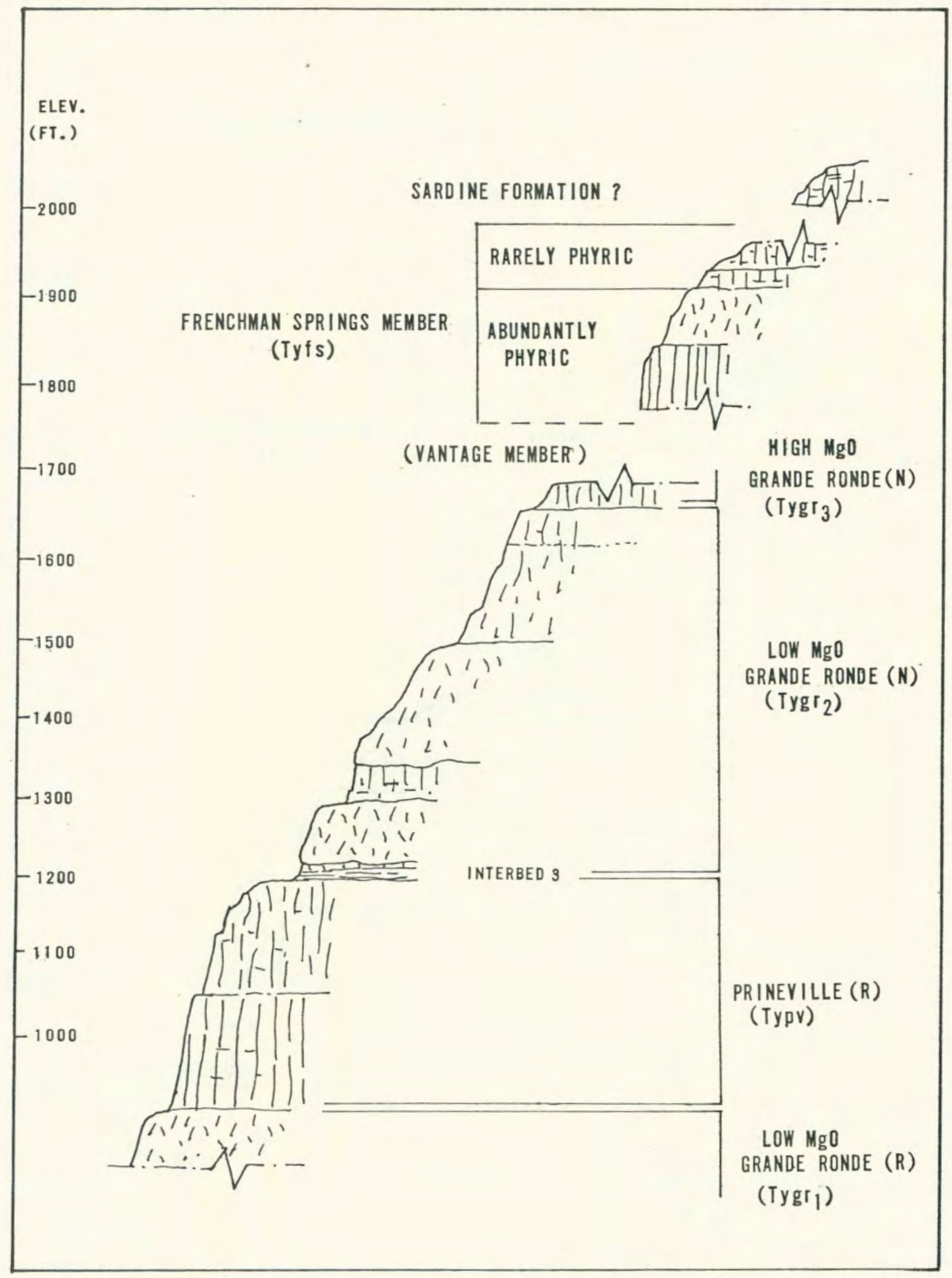

FIGURE 43. BIG EDDY STRATIGRAPHIC SECTION 


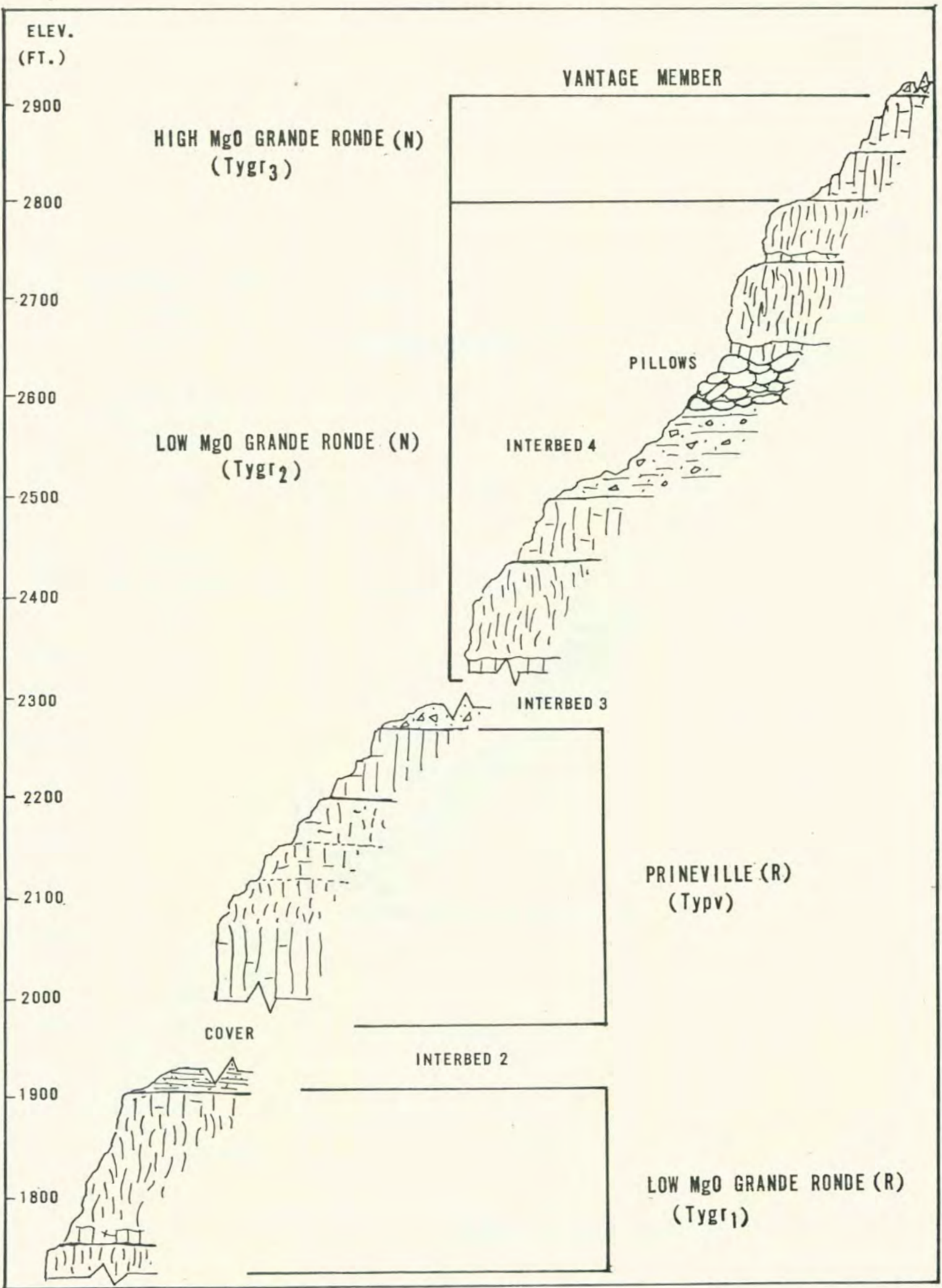

FIGURE 44. CRIPPLE CREEK STRATIGRARHIC SECTION 


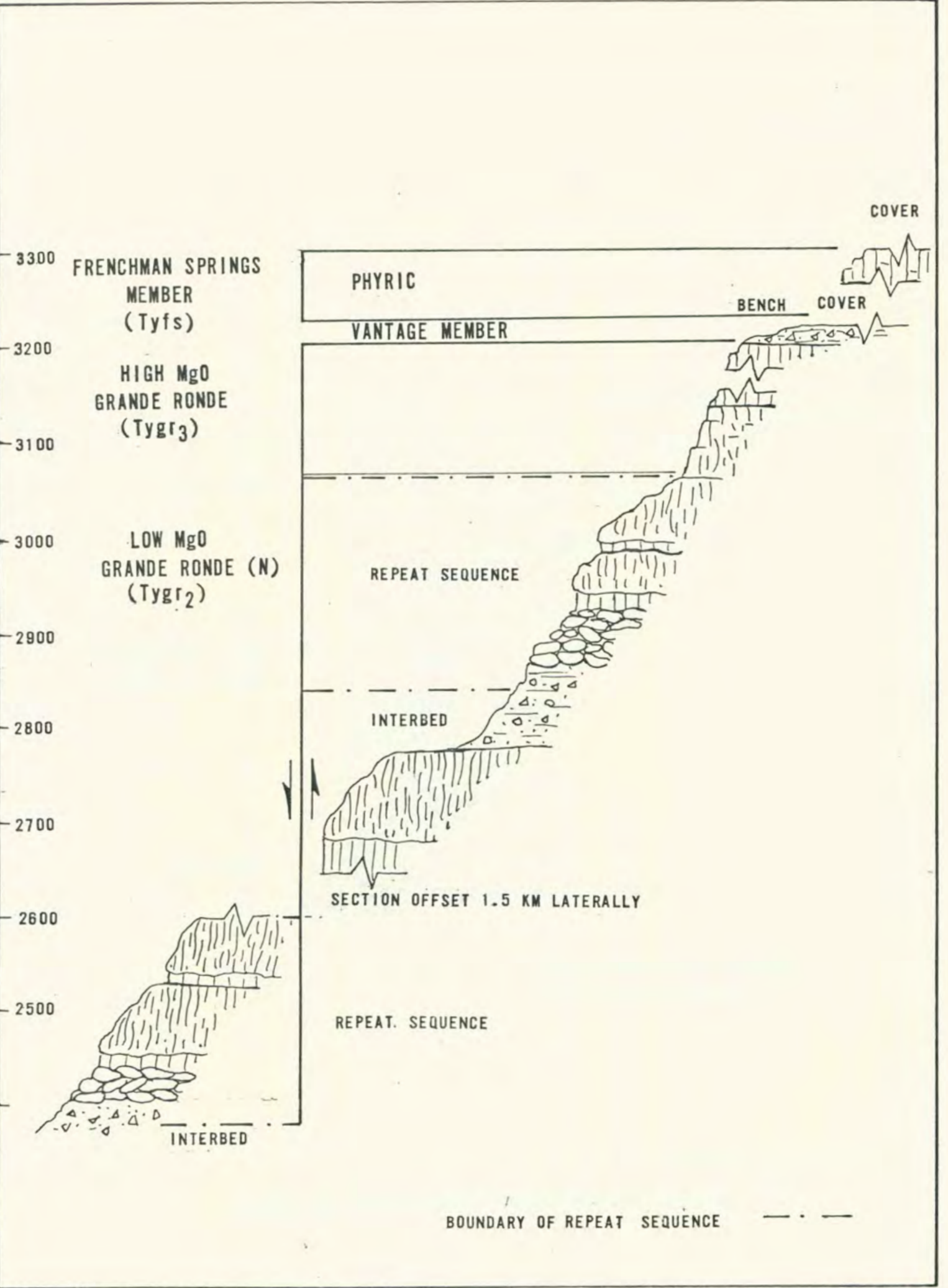




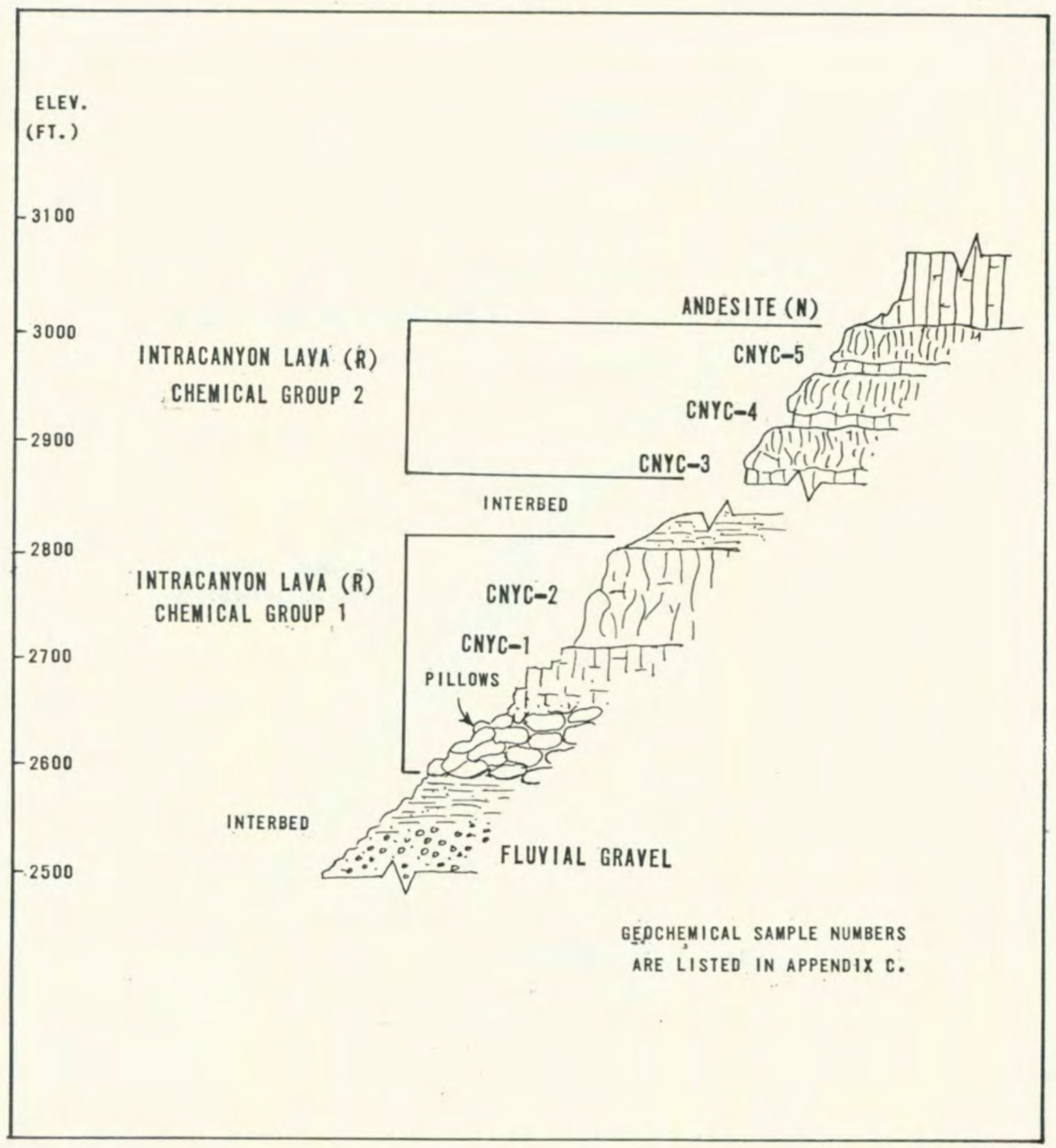

FIGURE 46. CANYON CREEK STRATIGRAPHIC SECTION 


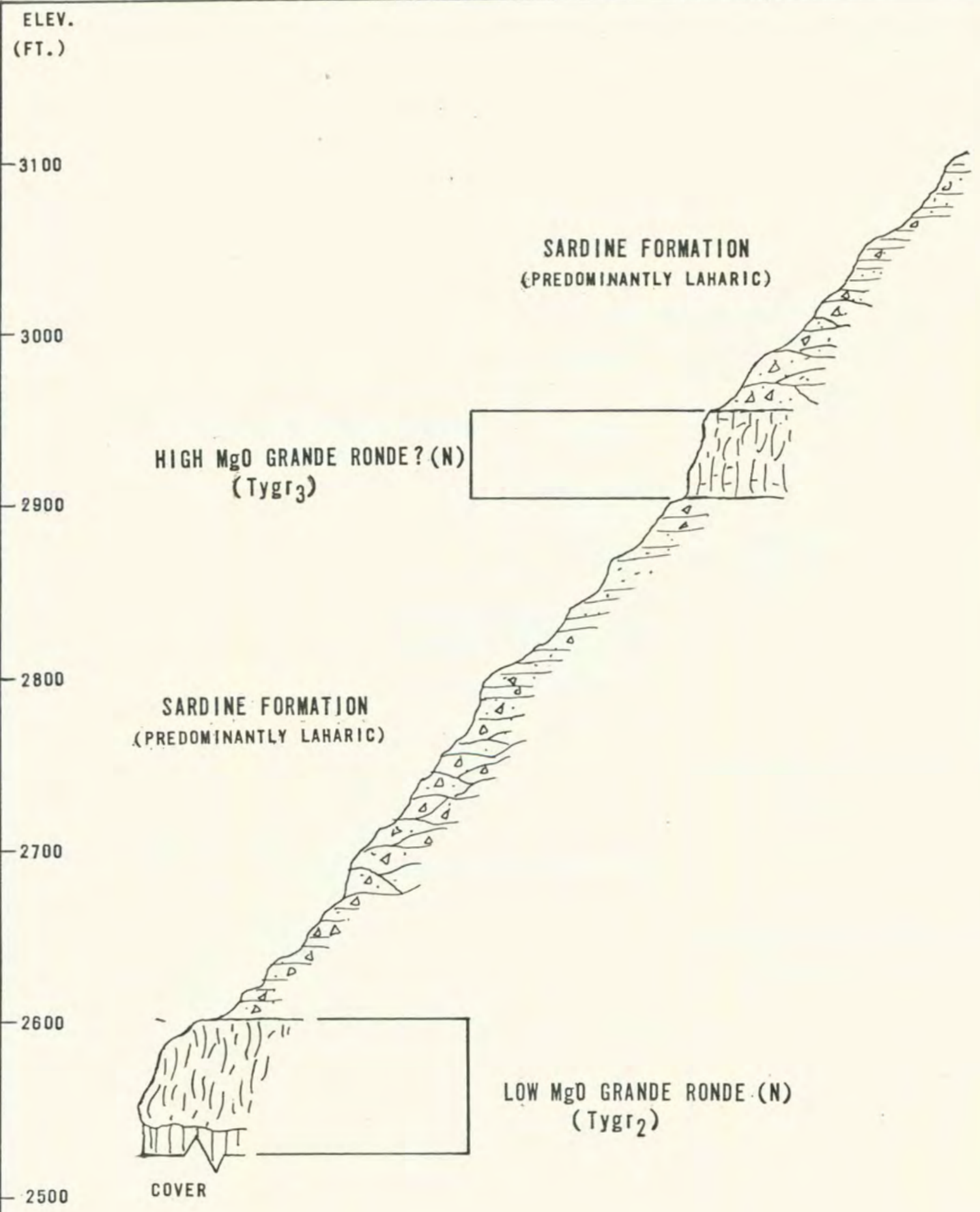


ELEV.

(FI.)

FRENCHMAN SPRINGS MEMBER (Tyfs)

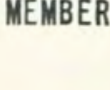

$-3100$

$-3000$

WOOD AND OPAL

SARDINE FORMATION

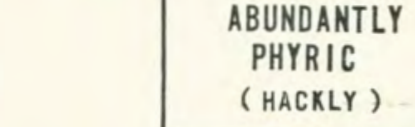

VANTAGE MEMBER

(SARDINE FM?)

PHYRIC

PHYIC
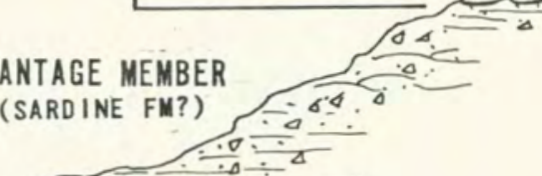
ELEV.

(FI.)

$-1600$

$-1500$

FRENCHMAN SPRINGS

MEMBER

( Tyfs )

$-1400$

ABUNDANTLY PHYRIC

PHYRIC

RARELY PHYRIC

OFFSET SECTION . 4 KM

$-1300$

$-1200$

HIGH MgO

GRANDE $\cdot$ RONDE

$\left(\operatorname{Tyg}_{3}\right)$
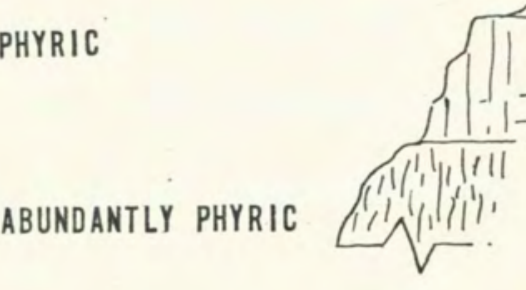

ABUNDANTLY PHYRIC
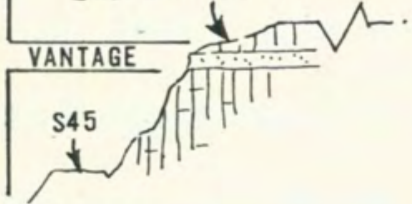


\section{APPENDIX C}

\section{TRACE ELEMENT GEOCHEMISTRY}

A total of forty-three rock samples were selected to be analyzed using instrumental neutron activation in two separate experiments. Twenty grams of fresh uncontaminated chips selected from each sample were powdered by hand to $80 \mathrm{mesh}$ and then split to one gram samples. All samples were subjected to irradiation with thermal neutrons in the Reed college Triga reactor at a flux of approximately $2 \times 10^{12} \mathrm{n} / \mathrm{cm}^{2} \mathrm{sec}$ (250 kw) for one hour.

Experiment 7-G was irradiated at 22:00, April 28, 1977. Two counts were conducted, the first on May 4 th and the second on May 16th. Irradiation of experiment 7-5 was accomplished at 22:16 on May 18, 1977 with counts conducted on May 26th and June 8th. Six Clackamas River samples were included in experiment 7-G and thirty-seven in experiment 7-5.

The United States Geological Survey standard for Columbia River Basalt, $B C R-1$, was included in each experiment and was counted for twice the length of time of other samples in each count. Values for elemental concentrations in BCR-1 were taken as the best values listed in Flanagan (1973).

Data processing was accomplished with the PDP-11 and Harris 200 computer systems, using existing programs. Summary listings of concentrations of elements identified in 
the first and second counts of experiments 7-G and 7-5 appear on the following pages of this appendix, along with unit identities. Concentrations are in parts per million unless otherwise noted, and relative error is included for each value. 
TABLE VII

TRACE ELEMENT GEOCHEMICAL ANALYSES (INCLUDING Fe \& Na)

SAKPLE

TLYX $\rightarrow 70$

TLYX-16
TLYX-15
TLYX-14

TLYYX-14

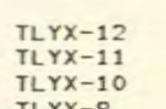

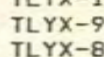

TLYX-7

TLYX-5

TLYXX-3

TLYX-2

RRNG -4
RRNG 3
RRNG -2

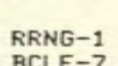

BCLF-6
BCLF-5
BCLF-4

BCLF-3
BCLF-2
BCLF-1

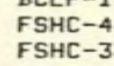

FSHC-2
FSHC-1
FSHA-5
FSHA-4

FSHA-2

CNYC 5

CNYC
CNYYC 4
CNYC 3
CNYC
CNYC
CNYC

$\begin{array}{lll}\text { STA } & 17 \\ \text { STA } 21 & 21\end{array}$
2.96 $\begin{array}{llll}27.96 & 0.05 & 11.90 & 1.10 \\ 1.83 & 0.04 & 27.60 & 2.20 \\ 2.36 & 0.05 & 23.90 & 1.10\end{array}$ $\begin{array}{llll}1.98 & 0.04 & 26.60 & 1.10\end{array}$ $\begin{array}{llll}2.05 & 0.04 & 18.10 & 1.00 \\ 2.09 & 0.04 & 18.90 & 1.00\end{array}$

$\begin{array}{llll}2.33 & 0.04 & 27.00 & 1.30 \\ 2.39 & 0.04 & 25.60 & 1.20\end{array}$ $\begin{array}{llll}2.37 & 0.04 & 25.60 & 1.30 \\ 1.91 & 0.03 & 24.60 & 1.10 \\ 2.48 & 0.04 & 26.30 & 1.30\end{array}$

$\begin{array}{llll}2.36 & 0.04 & 26.60 & 1.20 \\ 2.96 & 0.05 & 34.40 & 1.80\end{array}$ $\begin{array}{llll}2.29 & 0.04 & 19.30 & 1.00 \\ 2.15 & 0.04 & 20.90 & 1.10 \\ 2.25 & 0.05 & 26.80 & 1.30\end{array}$

$\begin{array}{llll}2.29 & 0.04 & 25.90 & 1.20 \\ 2.08 & 0.04 & 19.80 & 1.10\end{array}$

$\begin{array}{llll}2.31 & 0.04 & 28.70 & 1.20 \\ 2.45 & 0.05 & 29.00 & 1.40 \\ 2.13 & 0.05 & 24.60 & 1.30\end{array}$

$\begin{array}{llll}2.45 & 0.05 & 26.80 & 1.30 \\ 2.63 & 0.05 & 30.30 & 1.30 \\ 2.73 & 0.05 & 28.10 & 1.30\end{array}$

$\begin{array}{llll}2.73 & 0.05 & 28.10 & 1.30 \\ 2.19 & 0.05 & 26.60 & 1.30 \\ 2.42 & 0.05 & 27.90 & 1.40\end{array}$

$\begin{array}{llll}2.53 & 0.05 & 25.90 & 1.30 \\ 2.42 & 0.05 & 23.90 & 1.20 \\ 2.12 & 0.04 & 17.00 & 1.00 \\ 2.16 & 0.05 & 21.70 & 1.20 \\ 2.30 & 0.04 & 27.70 & 1.20\end{array}$

$\begin{array}{llll}2.20 & 0.04 & 24.90 & 1.10 \\ 2.33 & 0.04 & 27.90 & 1.20\end{array}$

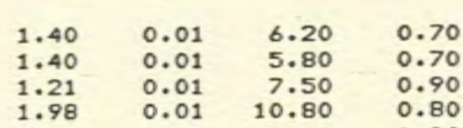

$2.06 \quad 0.01 \quad 10.40$

$\begin{array}{rrrr}2.60 & 0.02 & 8.70 & 0.90 \\ 3.24 & 0.02 & 13.10 & 1.00\end{array}$ $\begin{array}{ll}28.00 & 3.00 \\ 64.00 & 4.00\end{array}$

$\begin{array}{ll}53.00 & 4.00 \\ 48.00 & 4.00\end{array}$

$\begin{array}{ll}51.00 & 4.00 \\ 52.00 & 4.00 \\ 35.00 & 3.00\end{array}$

$\begin{array}{ll}45.00 & 4.00 \\ 57.00 & 4.00\end{array}$

48.00
50.00
47.00
57.00
58.0

49.00
56.00

37.00
42.00
50.00

61.00
39.00

38.00
45.00

47.00
54.00

57.00
49.00
54.00

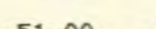

38.00
35.00
45.00

46.00
48.00

$\begin{array}{ll}26.00 & 3.00 \\ 24.00 & 3.00 \\ 29.00 & 3.00 \\ 27.00 & 3.00\end{array}$

$\begin{array}{lll}23.00 & 3.00 & 2.85 \\ 20.00 & 2.00 & 2.57\end{array}$

$4.00 \quad 7.01$

$\begin{array}{ll}4.00 & 8.96 \\ 4.00 & 5.52 \\ 4.00 & 5.74 \\ 4.00 & 6.65\end{array}$

$\begin{array}{ll}4.00 \\ 4.00 \\ 3.00 & 6.26\end{array}$

$\begin{array}{ll}00 & 2.89 \\ 00 & 2.88 \\ 00 & 2.99 \\ 00 & 4.26 \\ 00 & 4.02\end{array}$
EU

$\begin{array}{ll}0.15 & 1.70 \\ 0.20 & 6.20 \\ 0.20 & 5.00 \\ 0.20 & 6.70 \\ 0.20 & 4.40\end{array}$

TH $\mathrm{HF}$

0.90
1.30

$\begin{array}{llll}.20 & 20.60 & 1.50 & 4.97\end{array}$

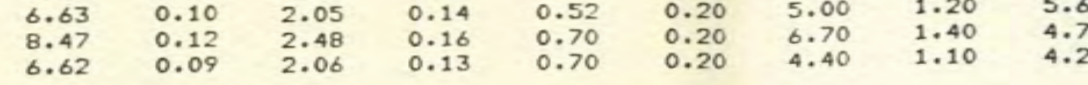

$\begin{array}{llllllll}.20 & 0.09 & 2.19 & 0.13 & 0.56 & 0.20 & 5.80 & 1.20 \\ .95 & 0.09 & 2.23 & 0.14 & 0.57 & 0.20 & 4.80 & 1.10 \\ .24 & 0.08 & 1.70 & 0.12 & 0.44 & 0.17 & 4.00 & 1.00 \\ .57 & 0.08 & 1.89 & 0.12 & 0.61 & 0.20 & 3.70 & 1.00 \\ .54 & 0.09 & .19 & 0.13 & 0.70 & 0.20 & 7.20 & 1.30\end{array}$

$\begin{array}{llllllll}6.79 & 0.10 & 2.19 & 0.14 & 0.80 & 0.20 & 8.60 & 1.50 \\ 0.25 & 0.09 & 1.75 & 0.12 & 0.57 & 0.19 & 8.00 & 1.30 \\ 6.83 & 0.10 & 2.06 & 0.13 & 0.60 & 0.20 & 7.50 & 1.30 \\ 0.49 & 0.10 & 4.50 & 0.20 & 0.70 & 0.20 & 5.30 & 1.20\end{array}$

$\begin{array}{lll}8.49 & 0.10 \\ 9.40 & 0.11\end{array}$

0.10

$\begin{array}{lll}0.09 & 0.10 \\ 82 & 0.00\end{array}$

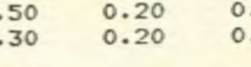

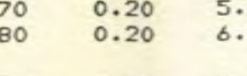

$\begin{array}{lll}0.15 & 7.40 & 1.30 \\ .18 & 9.50 & 1 . \\ .20 & 4.20 & 1 . \\ .20 & 6.30 & 1.20 \\ .20 & 7.70 & 1.40 \\ 0.20 & 7.20 & 1.30\end{array}$

$\begin{array}{lll}.80 & 0.12 & 0.13 \\ .05 & 0.14 & 0.80\end{array}$

$\begin{array}{lll}00 & 6.51 & 0.09 \\ 00 & 5.57 & 0.10 \\ 4.00 & 6.72 & 0.09\end{array}$

$\begin{array}{lll}4.00 & 7.01 & 0.11 \\ 4.00 & 5.99 & 0.10\end{array}$

$\begin{array}{rrrr}4.00 & 6.83 & 0.10 \\ 4.00 & 9.88 & 0.12 \\ 4.00 & 10.13 & 0.12\end{array}$

$\begin{array}{llllllll}0.10 & 1.84 & 0.13 & 0.45 & 0.20 & 6.80 & 1.30 & 5.90 \\ 0.12 & 4.20 & 0.20 & 0.80 & 0.20 & 6.80 & 1.30 & 3.50 \\ 0.09 & 1.75 & 0.12 & 0.46 & 0.19 & 3.50 & 1.10 & 4.40 \\ 0.10 & 1.62 & 0.14 & 0.90 & 0.30 & 5.10 & 1.30 & 3.50\end{array}$

$\begin{array}{llllllll}0.10 & 1.62 & 0.14 & 0.90 & 0.30 & 5.10 & 1.30 & 3.50 \\ 0.10 & 2.04 & 0.13 & 0.70 & 0.20 & 8.00 & 1.40 & 4.30\end{array}$

$\begin{array}{llllllll}0.09 & 1.96 & 0.12 & 0.80 & 0.20 & 6.50 & 1.20 & 5.60 \\ 0.09 & 2.02 & 0.12 & 0.44 & 0.17 & 8.40 & 1.40 & 5.40\end{array}$

0.05
0.05
0.06
0.05
0.05

$\begin{array}{llll}.78 & 0.13 & 0.70 & 0.30 \\ .09 & 0.14 & 0.70 & 0.30 \\ .18 & 0.14 & 0.25 & 0 \\ .31 & 0.13 & 0.60 & 0.20 \\ .34 & 0.13 & 0.60 & 0.20 \\ 0.13 & 0.12 & 0.35 & 0.17\end{array}$

0.05

\section{EXPLANATION:}

FIRST COLUMN IS CONCENTRATION IN PARTS PER MILLION (FE \& Na IN \%)

SECOND COLUUN IS RELATIVE ERROR (SAME UNITS)

UNIT SYMBOLS FOR COLUMBIA RIVER BASALT ARE THE SAME AS THOSE USED ON GEOLOGIC MAP (FIGURE 12)

INTRA = INTRACANYON FLOW. N.C. $=$ NON COLUMBIA RIVER BASALT FLOW

OTHER SYMBOLS ARE SELF-EXPLANATORY 
APPENDIX D

\section{MAJOR OXIDE GEOCHEMISTRY}

Concentrations of eleven major oxides were obtained for one complete stratigraphic section within the Grande Ronde Basalt. The Three Lynx stratigraphic section (TLYX), detailed in Appendixes $A$ and $C$, was selected for this purpose. Analyses were performed by Dr. Peter R. Hooper at Washington State University, Pullman, Washington, using $x$-ray fluorescence spectroscopy. 


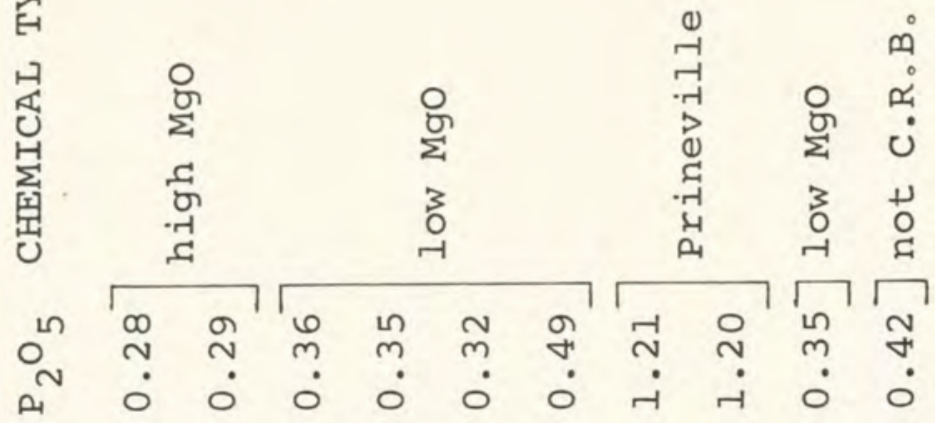

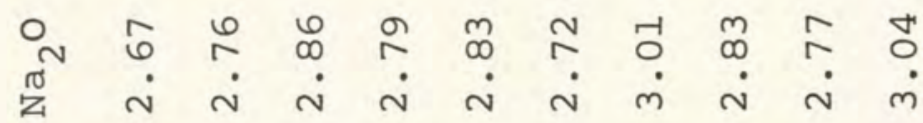

ॠ

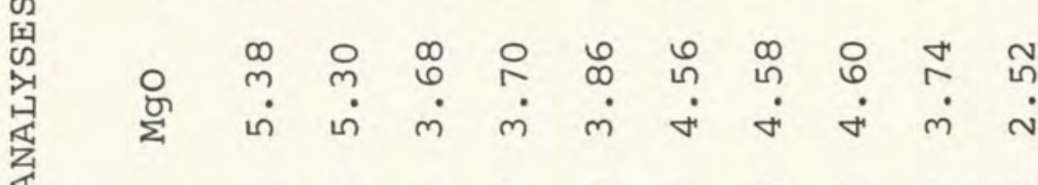

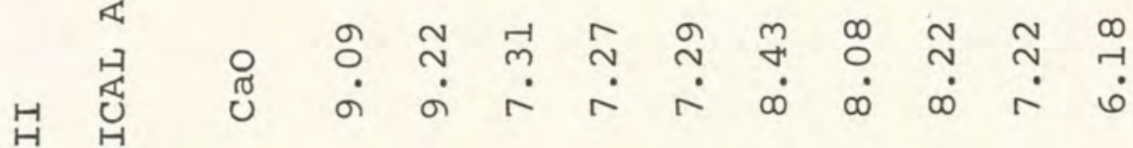

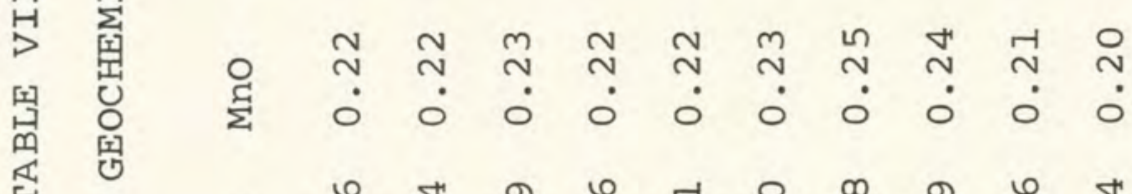

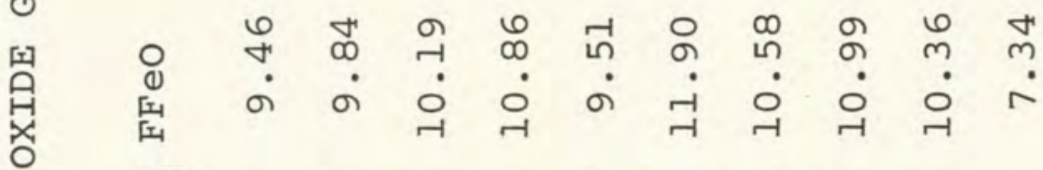

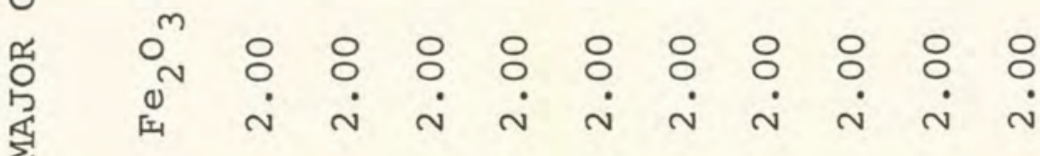

ov

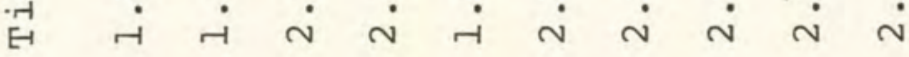

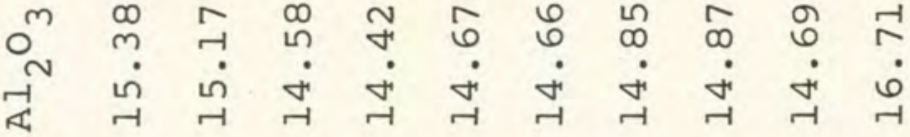

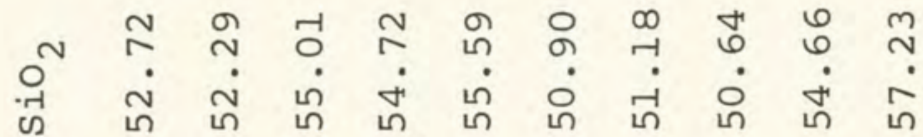

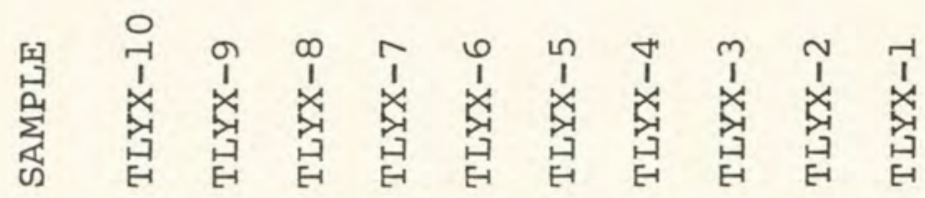

